\title{
Introducing problem-based learning into a traditional medical school : student and staff perceptions of the United Arab Emirates University's innovation
}

Citation for published version (APA):

Mpofu, D. J. S. (1999). Introducing problem-based learning into a traditional medical school : student and staff perceptions of the United Arab Emirates University's innovation. [Doctoral Thesis, Maastricht University]. Datawyse / Universitaire Pers Maastricht. https://doi.org/10.26481/dis.19991124dm

Document status and date:

Published: 01/01/1999

DOI:

10.26481/dis.19991124dm

Document Version:

Publisher's PDF, also known as Version of record

Please check the document version of this publication:

- A submitted manuscript is the version of the article upon submission and before peer-review. There can be important differences between the submitted version and the official published version of record.

People interested in the research are advised to contact the author for the final version of the publication, or visit the DOI to the publisher's website.

- The final author version and the galley proof are versions of the publication after peer review.

- The final published version features the final layout of the paper including the volume, issue and page numbers.

Link to publication

\footnotetext{
General rights rights.

- You may freely distribute the URL identifying the publication in the public portal. please follow below link for the End User Agreement:

www.umlib.nl/taverne-license

Take down policy

If you believe that this document breaches copyright please contact us at:

repository@maastrichtuniversity.nl

providing details and we will investigate your claim.
}

Copyright and moral rights for the publications made accessible in the public portal are retained by the authors and/or other copyright owners and it is a condition of accessing publications that users recognise and abide by the legal requirements associated with these

- Users may download and print one copy of any publication from the public portal for the purpose of private study or research.

- You may not further distribute the material or use it for any profit-making activity or commercial gain

If the publication is distributed under the terms of Article 25fa of the Dutch Copyright Act, indicated by the "Taverne" license above, 


\section{Introducing problem-based learning into a traditional medical school}

Student and staff perceptions of the

United Arab Emirates University's innovation 



\section{Introducing problem-based learning into a traditional medical school}

Student and staff perceptions of the

United Arab Emirates University's innovation

\section{PROEFSCHRIFT}

ter verkrijging van de graad van doctor aan

de Universiteit Maastricht,

op gezag van de Rector Magnificus,

Prof. dr. A.C. Nieuwenhuijzen Kruseman,

volgens het besluit wan het College van Decanen,

in het openbaar te verdedigen

op woensdag 24 november 1999 om 14.00 uur

door

Deborah Jean Sihle Mpofu

geboren te Chipinge, Zimbabwe, in 1956

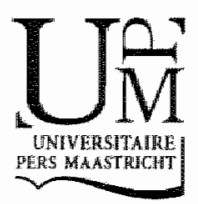


Promotor:

Prof.dr. H.G. Schmidt

Beoordelingscommissie:

Prof. dr. C.P.M. van der Vleuten (voorzitter)

Prof. dr. J.J.C.B. Bremer

Dr. D.H.J.M. Dolmans

Prof. dr. G.J. Kok

Dr. M.W.J. van de Wiel

ISBN 9052782598

Universitaire Pers Maastricht 


\section{CONTENTS}

1. Introduction

2. Effectiveness of problems used in problem-based learning.

Co-authors: M. Das, J.C.Murdoch \& J.H. Lanphear.

Published in Medical Education (1997) 31, 330-334

3. A Review of Problem-based Learning : perceptions

of students and tutors at the United Arab Emirates University.

Co-authors: H.G. Schmidt, M. Das, J. Lanphear \& E.Durn.

Published in Educalion for Healsh (1998) 11. 2, 203-213

4. Self and tutor evaluations in problem-based learning tutorials: is there a relationship?

Co-authors: M. Das, E Dunn \& J. H. Lanphear.

Published in Medical Education (1998) 32.411-418

5. Perceptions of group dynamics in problem-based learning sessions:

a time to reflect on group issues.

Co-authors: M. Das, T, Stewart, E. Dunn \& H Schmidt.

Published in Medical Teacher (1998) 20, 5, 421-427

6. Facility with the English Language and Problem-Based Learning

Group Interactions: Findings from an Arabic Setting.

Co-authors: J. Lanphear, T. Stewart, M. Das, P. Ridding \& E.Dunn

Published in Medical Education (1998) 32, 479-485

7. Summary and Conclusion

Samenvatting 



\section{PREFACE}

The studies described in this thesis were conducted at the Faculty of Medicine and Health Sciences (FMHS), United Arab Emirates (UAE) University.

In a fairly new medical school only a decade old, a major question was whether innovation in the form of Problem-Based Learning (PBL) was really necessary? Negative attitude by faculty staff to the idea of introducing PBL was highlighted in a study undertaken in 1991. On the other hand, policy makers had an idealistic perception of what medical education and training at the FMHS could be like. PBL and the promotion of self and active leaming were some of the key curriculum principles identified. In 1994 the FMHS decided to cautiously introduce change in the form of PBL into the Introduction to Medicine Module (ITMM) during the preparatory year (the first year) of the medical curriculum.

In June 1994, together with Dr Mandira Das, the ITMM coordinator, I attended a PBL training workshop and PBL conference at McMaster University. Following the McMaster experience, work on introducing PBL to the ITMM and work on this thesis began. In 1996, I attended a further PBL workshop at the University of Maastricht, the Netherlands. The final product of this thesis is the result of a team effort around the globe.

My promotor prof.dr. Henk Schmidt, used all forms of modern technology to keep me focused, and communicate fine details about the micro and macro aspects of the study. I am most thankful for your belief in me. Dr Mandira Das was a key support, her suggestions, ideas and leadership provided tremendous strength especially during difficult times. Dr Joel Lanphear, my copromoter, was facilitative in addressing not only the bureaucratic issues, but practical matters too. Professor Earl V. Dunn, I consulted about matters pertaining to data collection and more importantly the statistical aspects of the project. To Doctors Tom Stewart, Harith Swadi, Mohammed Hassan, your support and enthusiasm about the project was an important driving force.

Sincere thanks go to Morag McAuslin, whose cditing and attention to detail helped the presentation of my manuscripts. The referees of the various journals, your comments certainly helped develop an insight into this area. To the special fund through the Network of Community Oriented Educational Institutions for Health Sciences, I aun grateful for your financial assistance.

A big thanks to Diana Dolmans, for her encouragement especially with the very first study of the Ph.D. project. Further thanks go to Irma Kokx who at the $1996 \mathrm{PBL}$ workshop discussed possible research ideas relating to culture. Some of her ideas converted into the thinking behind the final study.

Finally I would like to thank my husband Chris, my three wonderful sons Sabe, Dumiso and Vukile. Your patience and love are a blessing. Last but not least I dedicate this thesis to my father, MacDonald Major, you always believed in me. 



\section{Introduction and Overview of the Thesis}

The study reported in this thesis aims to illustrate the wealth of information educators can obtain about aspects of the curriculum, especially the students, using innovative Problem-Based Learning (PBL). Historically, not only established medical schools but even fairly new medical schools, like the Faculty of Medicine and Health Sciences (FMHS), United Arab Emirates (UAE) University lean more towards traditional forms of education. Faculty are more comfortable with tradition. Maintaining the status quo is easier than accommodating the new "alien" ideas. For the students in many medical schools, progressing through the medical curriculum means survival of the fittest. Paying attention to an institution's unique curricula concerns and not treating medical education as the same the world over, is crucial. Innovation starts to highlight the unique curricula problems. These could vary from the recruitment process, the medium of instruction, faculty related issues to issues such as the institutional environmental aspects. $\mathrm{PBL}$ offers an opportunity to review aspects of the curriculum from a variety of perspectives, using qualitative methodologies. It is hoped that by providing the results of specific curricula related investigations into the system, needed growth and development will be promoted.

\section{The Thesis}

This thesis reports the investigations around the introduction of innovative practice into a medical curriculum. It focuses on feedback on aspects of PBL, from PBL students, PBL tutors and observers on a variety of issues pertinent to the innovation. In this instance PBL is an innovative educational mode being introduced as a small segment into a strongly teacher centred curriculum.

\section{Setting the scene}

For the study, in introducing PBL, it is not only the student group functioning with a facilitator that is important but the setting, the learning milieu, plays a crucial role.

It is a Saturday morning at $9 \mathrm{a} . \mathrm{m}$. the beginning of the working week, the temperatures range from 30-45 degrees Celsius. Often the desert wind brings with it heavy sand storms. During the cooler December to January months, maybe for two wecks out of the entire year a little rain falls teasingly around. A Canadian female professor in Family Medicine and a clinician, a male Lebanese Anacsthetist head to the male teaching rooms to take one of the Preparatory Year male groups of eight students for a PBL session. At 2 p.m. the two PBL tutors repeat the same PBL session with a group of nine female students, this time in the female teaching rooms. The students laugh and joke in Arabic as they are heading to the PBL rooms, and switch to English once the session begins. 
students, complimented by the distinctive Arabic head dress. The male students and the male anaesthetist rub noses as a form of traditional greeting. On the other hand, the clicking of fashion shoes and the silky black "abayas" remind you that you are in the female teaching area. Students and tutors greet one another traditionally, "Salam Alekum" "Walekum Salam". Both tutors and students have received orientation on PBL. Orientation covers the principles of PBL, the PBL steps, the roles of group members, the tutorial sessions, group interaction, information management skills, assessment and evaluation. This is part of the Introduction to Medicine Module (ITMM), a module that runs for the whole academic year, in the first year of medical education and training.

All students of the FMHS are UAE nationals who enter medical school after completing secondary school education and a one year Basic University Education Program. English is the medium of instruction in the FMHS. For all students, English is a second language. It is identified that for almost all the medical schools in the Arab world, English has been adopted as the language of instruction. The majority of precollege schooling is in a different language and therefore students experience related language problems during the course of medical schooling, (Swadi, 1997).

Each year 35-40 students enter medical school at FMHS, in general approximately two-thirds of the entrants are female. For cultural and religious reasons males and females are taught separately.

\section{The United Arab Emirates: A Brief Sketch}

Although the investigations were carried out in relation to medical education, it is important to understand the sociopolitical environment of the medical school.

The UAE was established as a loose confederation of seven separate states, called emirates in 1971. The discovery and exploitation of oil has provided for an incredible modernization over the past three decades. The nation was transformed from desert land, dependent on fishing, pearling, trading and "wadi" agriculture to a very complex consumer economy supported by modern transportation and communication systems, with a GDP comparable to any country in the developed world, (Gallagher
1993).

The "oil boom" has attracted a vast expatriate workforce, where expatriates presently outnumber citizens. In 1968 , the combined population of the seven emirates was about $180,00036 \%$ of whom were non-nationals. By 1980 , the population had grown to 2.5 million and the percentage of non-nationals had increased to $73 \%$ (Gardner 1995). The expatriate population carries out many vital functions from unskilled construction work, to skilled work in architecture, teaching, banking, petroleum geology, patient care and a variety of other professional and nonprofessional work, (Gallagher 1993). Gardner 1995, indicates that the twin dominance of both the workforce and the total population by non-nationals has caused anxiety among the nation's leaders because too much of the nation's future is in the hands of a foreign population. Thus, the UAE leadership encourages large families amongst its old males and almost universal amongst females, virtually all children today receive at 
least primary school education. Education of nationals including medical education is well supported by the government. In relation to health care delivery, the leadership aims at not only producing its own UAE physicians, but physicians who are comparable to the best in the world. It is identified that health care is an important vector of modernity in two senses: directly, for its powerful practical effects in curing or alleviating illness; and symbolically for its representation of a society"s capacity to mobilize the agents and instituional structures that can implement biomedical science to human benefits. With physicians leading the charge, so to speak, against illness, medical education is a particularly strategic component of a society's health effort and index of its modernization, Gallagher (1993). Islam is the state religion of the UAE. Arabic is the official language, although languages like English, Hindi, Tagalog to name a few, are spoken widely. Within the research context, male students versus female students' differences in various aspects of the research studies are of particular interest as: a) UAE women have traditionally played a dominant role in domestic and family affairs where, their public role was very limited; b) although women are slowly entering the workforce into business, management and secretarial positions the majority are still mainly in the occupations of teacher, social worker and a limited number of physicians. There is still greater encouragement for fenales to work in areas in which they deal more with fernale clients.

\section{The Wider Historical Background of Importance to the FMHS, UAE University}

Around 1910, Flexner introduced the biomedical approach into medical education. The emphasis of his approach was on producing high-quality physicians by increasing the scientific knowledge and emphasizing medical practice (Magzoub 1994). Flexner's model was adopted by medical schools in both developed and developing countries. This meant the amount of knowledge medical students had to acquire and the number of specialists who had to teach this knowledge increased tremendously. However, in the seventies calls for education reform using problem-solving rather than rotememory, stressing active rather than passive learning and emphasizing student-centred rather than teacher-centred education followed. These ideas were woiced by the Association of American Medical Colleges (AAMC) 1984 panel on the General Professional Education of the Physician (GPEP) in a report entitled "Physicians for the twenty-first century". In addition, in 1978, following the Alma Ata declaration on primary health care, worldwide awareness of the importance of primary health care and equity in service delivery was realized. The Alma Ata conference confirmed the need for a new look at health profession education. The worldwide awareness of the global problems in conjunction with the promotion of health for all by the year 2000 brought with it major concerns. One growing concern was the necessity to adjust health manpower development to the real health needs and demands of the population, namely the "health manpower development concept" Fulop (1985).

The question of relevance of medical education to the health needs of the nation has received world-wide attention. The Edinburgh declaration (World Federation on Medical Education, 1989) which stemmed from a conference organized in response to the GPEP report received world-wide support. A delegation from the United Arab 
Emirates University, Faculty of Medicine and Health Sciences participated in this conference. The FMHS thus, was interested in promoting knowledgeable, high quality physicians, comparable to any other physicians the world over. Simultaneously, the UAE wanted to produce its own physicians responsive to the health needs of the country.

\section{The History of the FMHS UAE University, and identified curricula gaps}

At the time of the establishment of the FMHS at UAE University in 1986, a number of key curriculum principles were defined. Two of these principles were: 1) The curriculum will promote and facilitate: a) self-directed learning by students, b) active rather than passive llearning; 2) A variety of teaching / learning methods will be used with an emphasis on problem-based learning (Lanphear, 1991).

In theory, the FMHS supported the above principles. However, there was no real implementation of them in everyday practice. In a study undertaken in 1991, there was lack of understanding of what the principles were, and there was a general reluctance and resistance to the idea of PBL (Abdulrazaq \& Qayed, 1991). Simultaneously, at the FMHS, UAE University in 1990/1991 due to a number of factors working together, an environment was created for curriculum revision. These factors were:

- Rapidly expanding faculty members experienced in FMHS teaching and eager to contribute;

- Growing experience in teaching UAE medical students;

- Better understanding of health care needs in the UAE;

- Concern especially with pre-medical teaching entirely in Arabic, whereas the integrated medical curriculum emphasized problem-solving and was in English;

- An interest in aligning the curriculum with the curriculum principles identified from the outset. However, the faculty had not resolved the question of the extent to which the curriculum would be problem-based or problem-oriented and there was a clear need to better address the community aspects of health care, including non-hospital medicine;

- International developments in Medical Education. - The Edinburgh Declaration called for altention to active learning by students. It also called for institutions to reward good teaching and asked faculty to teach prevention as well as management of disense. Finally, it called for integration of education in service and practice and for fostering problem-solving in clinical and community settings;

- Curricular changes in the United Arab Emirates.

Lanphear (1991) pp $217-219$.

In 1991, the FMHS medical curriculum which had only been in existence since 1980 was therefore revised. Major gaps still existed as indicated above in the areas of PBL, self directed learning and increased community involvement. The major breakthrough, however, in the system was the course module integrated system. Therefore, from here units. The seven year curriculum included a one year internship. The first year, namely the Preparatory Course comprised of the following modules: Physical sciences; 
Biological sciences; Communication and Study Skills and Introduction to Medicine. In the second year the Integrated Biology and Medical Sciences (IBMS) Course was offered. IBMS comprised of four modules, namely: Basic Medical Sciences; Human Sciences; Developmental Sciences and Biological Sciences. These two years therefore provide the background for entering years three and four in the Organ Systems Course. This was then followed by two years of Clinical Clerkships, where students rotated through the clinical specialties.

The real dilemma at the FMHS was a philosophy that was supported by the government, the advisory groups and the administration, but not the power players within the traditional academic departments - the chairmen. However, attendance at the World Summit on Medical Education in Edinburgh in 1993, left some key faculty keen to investigate aspects like PBL further. Experts from McMaster University were invited to conduct an intensive workshop on PBL. The attending Dean, Associate Deans, Course Directors, Module Coordinators and Faculty staff agreed to proceed to work towards implementation of the earlier identified key curriculum principles. A PBL program was therefore designed and implemented in the Introduction to Medicine Module (ITMM) of the Preparatory course from 1994/1995.

The ITMM covered six PBL thematic units, namely: Health Care System, Environment and Health, Alternative and Islamic Medicine, Family Health Issues, Infectious Diseases, Prevention and Health Promotion. These six PBL themes were later reduced to five themes for a variety of reasons. The aims of the ITMM were to provide the medical students an insight into the:

1. Health care system of the United Arab Emirates

2. Socio-cultural, psychological, and environmental factors which affect health of the individual, family and community.

3. The approach to alternative therapies in UAE, disease prevention and health promotion.

4. Methods of clinical examination.

One of the themes in the ITMM which ran for four wecks was called Environment and Health. The objectives for this theme were as follows:

- to identify environmental factors related to health and disease;

- begin to identify measures for preventing diseases due to environmental factors

Simultaneously students were introduced to:

- the principles of First Aid

- common First Aid measures

The PBL trigger used was based on local issues, concerns and identified problems that are common in UAE, and in keeping with the theme title.

Environment and Health PBL trigger

\section{Problem Title-Sayed Ahmed and his environment}

Sayed Ahmed, complaining of difficulty breathing and sore eyes, was brought to the local hospital's Emergency Department. Sayed is anxious as he imhaled all sorts of fumes from a fire. Would this lead to tuberculosis he keeps asking? Sayed has worked 
as a laborer in the construction sites in Abu-Dhabi Emirate for the past fifteen years. A building in his neighbourhood caught fire. Sayed joined the fire-fighters in evacuating people and putting out the fire in the multi-storied building.

Following clarification of the meaning of words, students identified learning issues and divided them into the following categories; biological, community, educational, ethical and critical appraisal. The first year students discussed the issues arising from the problem trigger. The students using their prior knowledge, explained to each other their understanding of the issues related to the PBL trigger. Each PBL category was then summarized into a major and a minor objective. For example, the major biological learning objective was; the anatomy and physiology of the upper and lower respiratory tract. Minor objective were; 1) the effects of inhaling fire fumes on the respiratory tract, 2) the effects of tuberculosis on the respiratory tract. Some Community objectives were the incidence of fire accidents in the UAE, and the incidence and prevalence of tuberculosis amongst nationals and expatriates in UAE. For critical appraisal the local reports on fire accidents and tuberculosis would be compared with those of other countries etc. etc. On an ongoing basis students generally referred to the facilitators for confirmation as to whether they were on the right track or not. Now and again students consulted the dictionary for clarification of the meaning of words. Illustrations on the board accompanied much of the discussions. The students used their prior knowledge in the analysis of aspects related to the trigger. In some cases they had difficulty trying to verbalize the appropriate English terminology. Some students struggled on in English, at times consulting the tutor. Other students reverted to using Arabic at this point and returned to English when they were satisfied with the Arabic explanations given. Following possible analyses of the problem, learning objectives were clarified. Then, identification of appropriate learning resources was undertaken. The learning resources included library materials, computer search, First Aid and other exercises in the skills laboratory. Some students would consult public health, hospital emergency and other facilities. Still others would seek out FMHS faculty, senior colleagues and views of the public on ethical issues. Informal evaluation of self, peers and tutor(s) concluded each PBL classroom experience. In this case the presence of experts on the subject under discussion is evaluated very positively by the students at the end of this session. Each PBL session was followed by self-directed study periods. The report back phase was undertaken a week later before progressing to the next PBL trigger (Table 2). Multiple choice questions, Modified essay questions, a related project and objective structured clinical exam would be the methods of assessment used at the end of each semester. This assessment would cover two or sonetimes three thematio units of study.

\section{Why was the innovation necessary?}

In a new medical school only a decade old, why would change be necessary? Why move from traditional practices to PBL? The innovation was necessary for several reasons. Firstly, the FMHS aspires to be a medical school comparable to other medical schools around the world. Therefore, there was a need to respond to international 
recommendations like the Edinburgh Declaration, which called for active learning, integration in service and practice, problem- solving etc. Secondly, during the $1990 / 91$ curriculum revision a need was identified to align the medical curriculum with the FMHS curriculum principles identified at the inception of the FMHS in 1986. This would involve introducing problem-based learning, self-directed learning, and demonstrating a greater degree of community orientation within the curriculum. Further here, from a local perspective the FMHS Chancellor had made recommendations to move towards active leaming where, $\mathrm{PBL}$ is the prime method of active learning. Finally, the previously mentioned curriculum revision highlighted concern in relation to the integrated medical curriculum being in English, when premedical teaching was entirely in Arabic. These collective issues pointed towards at move to more student centred problem-based learning, granted, with appropriate monitoring, review and feedback.

It is important to note that in 1991, an investigation at the UAE University, FMHS reported little understanding of what Problem Based Learning (PBL) was about amongst faculty members. The same investigation identified open hostility by some faculty towards the idea of introducing PBL (Abulrazzaqi \& Qayed, 1991). Three years later a study published in 1994 using the 'SPICES Continuum' showed that the FMHS faculty believed then, that the use of a student-centred, problem-based, integrated and community oriented curriculum with electives would be more appropriate than the defined traditional practices (Das, Lanphear \& Ja'afar, 1994). From the above, therefore, it was timely to introduce problem-based learning and some degree of community oriented learning into the medical curriculum, with appropriate monitoring and review. It was also important to examine the PBL user's perspectives, both staff and students, on the innovation, and feed these back into the system. From the students perspective there was a need to investigate several areas within the innovative structure. Firstly, to investigate whether the FMHS students were able to not only use $\mathrm{PBL}$, but also to work in small groups. Secondly, the move from pre-university education in Arabic to medical education in English had been identified as problematic; could the innovation help to define the problem more concisely? Finally, to determine overall any positive as well as negative aspects of the innovation. For the study therefore, following some of the recommendations by Kantrowitz, Kaufman, Mennin, Fulop \& Guilbert, (1987), a limited segment of the medical curriculum was selected to introduce and monitor the innovation, for the following reasons:

\section{Minimization of threat to traditional faculty}

Selecting a small segment of the curriculum allows a small group of committed faculty and students to try out new types of curriculum without initially forcing the rest of the faculty either to change what and how they teach, or to participate in the innovation. Study 2, (Chapter 3) entitled A Review of PBL over five themes: perceptions of studens and rutors at the UAE University, uses a questionnaire adopted from Majoor, Schmidt, Snellen-Ballendog, Moust, Stalen hoef-Halling (1990) to identify the merits of PBI. There is an attempt to scrutinize the PBL process adopted and to highlight both positive and negative aspects related to the innovation. In this instance the 
innovation was only introduced to the Introduction to Medicine Module (ITMM) and used wolunteer tutors only.

\section{Bypassing of departmental power bases}

The innovation brought together educators from different departments who place students education needs above departmental concems. The goal of offering an integrated curriculum can be undermined by traditional departmental control of curriculum evaluation. Study 2, referred to above, used tutors facilitators from eight different departments in the review of PBL. This was supported overall by the new curriculum model.

\section{Providing a protected environment}

Innovative practice like ours, allows room for ideas to be tested and modified until it is clear which ideas work and which ones do not. Innovation needs time and space to develop and modify new approaches. One major concern at the FMHS was whether students could comprehensively address necessary learning material in PBL. Study 1 , (Chapter 2) entitled Effectiveness of problems used in problem-based learning used the degree of congruence between staff objectives and student generated learning issues to assess effectiveness of PBL triggers used over five thematic study units. Previous studies by Coulson and Osborne (1984) and later by Dolmans (1994) demonstrated students to identify approximately $60 \%$ of the learning issues intended by staff. The need was felt to replicate the study in a Middle-East location, using objectives and PBL problems designed locally.

Further, here, introducing students to self and peer appraisal was identified as a professional skill essential for the success of every doctor in maintaining professional competence. How would our FMHS students handle self-evaluation? Could selfevaluation be introduced into the summative or formative assessment systems for the respective years? Study 4 (Chapter 5) entitled Self and Tutor evaluations in problembased leaming morials: is there a relationship? sought to review the role of self evaluation by first year students as opposed to tutors during PBL sessions over two academic years. The study used a fifteen item questionnaire adopted from Rangachari \& Crankshaw (1992). The fifteen items represented five subscores; responsibility, information processing, communication, critical analysis and self awareness. These five subscones were rated on a scale from 1 to 5 , from disagree to agree. An overall rating was also required at the end of the form, and a space for comments about selfevaluation, was provided.

Identifying how useful or otherwise self-evaluation would be, was seen as a worthwhile exercise in encouraging student identification of areas for self development and encouraging the students greater responsibility for their own learning.

\section{Offering an innovative approach to learning}

This study gave students an opportunity to not only use a novel approach to leaming but also the facility to stand back and reflect on positive and negative aspects of learning in small groups. Study 4, (Chapter 5 ) entilled Perception of group dynamics in PBL leaming sessions: a time to reflect on gromp issues, offers students and tutors not 
just the use of PBL approach to learning but opportunity to review positive and negative aspects of group functioning. The majority of the FMHS first year medical students had no previous experience of learning in groups. Using a survey form adapted from Tipping, Freeman \& Rachlis, (1995) medical students and PBL tutors reviewed the following categories of group behaviour over four thematic siudy units; physical climate, emotional climate, involvement, interaction, cohesion, productivity, the student as group leader, and finally, the tutor as facilitator.

The experience of working in small groups would hopefully identify general as well as specific group dynamics issues, important in adapting PBL as a mode of learning.

\section{Confirming or refuting rumours of importance to students education}

It is crucial and extremely important to undertake research that confirms or refutes anecdotal reports. Not only with the FMHS, but with other schools as well, it is not uncommon to see faculty vote against introducing a new approach to student learning because anecdotal evidence suggests students may not cope with the innovation. It is important to provide research evidence which forms the bases for suggested recommendations. At the FMHS, English Language, communication in English, interaction using English were repeatedly highlighted as some areas of concern for the students (Das, Murdoch, Mpofu \& Benner 1996; Harrison, Glasgow, Townsend 1996; Swadi 1997; Mpofu, Das, Stewart, Dunn \& Schmidt 1998; Mpofu, Schmidt, Das, Lanphear \& Dunn 1998.) Study 5, (Chapter 6) entitled Facility with ihe English language and Problem-Based Leaming Group Interaction: Findings from an Arabic Setting, focuses on the issues of student proficiency with English as measured by the Test of English as a Foreign Language (TOEFL), student background factors and interaction in Problem-Based Learning groups. Using a modification of Bales Interaction Process Analysis (IPA), four PBL groups were observed over four thematic study units, to measure the degree of student interaction within PBL groups and to compare this to individual TOEFL scores and key background variables.

This final study would highlight more clearly and more specifically the problem the students were experiencing with the use of the English language, as identified in PBL small group situations.

The collective findings from the above five studies are viewed as tools to promote curricula dialogue and a promotion of curricula modifications.

The issues the thesis addresses, both directly and indirectly therefore are as follows:

- Could PBL be an appropriate learning method for UAE Arabic students?

- Could students use PBL as intended?

- What were the merits of introducing a new PBL programme at FMHS?

- Was PBL acceptable to tutors, and students as an approach to learning?

- How did the students perceive working as a group in PBL, when they had no experience of group learning?

- PBL uses post session evaluation by participants, how useful was self-evaluation to students and how was self-evaluation perceived by both students and tutors?

- Did proficiency with English affect students interaction in PBL groups? 
Chapters $2-6$ of the thesis are articles published in various journals, these chapters report the investigations carried out in relation to the above reported questions. Some issues are over explained for clarity to the reader of the individual journals the articles were prepared for. The relationship between the chapters is therefore presented graphically in Figure 1.

The introductory chapter of this thesis describes the educational context in which the innovation was conducted. There is also an attempt to briefly highlight the sociopolitical context of the country where the study was based. In chapter 2 , the learning environment and the PBL process is described as adapted at the FMHS, in order to give the reader an understanding of the prevailing educational conditions. The identification of relevant learning issues as a measure of student learning has been used in several studies (Dolmans 1994, Coulson \& Osborne 1984). In chapter 2, an investigation was undertaken to measure problem effectiveness. During PBL, the extent to which the students identify relevant learning issues when exposed to prepared problem triggers is indicated as demonstrating how effectively the problems were constructed from faculty objectives. At the FMHS it was necessary to repeat the study from a local perspective, and second, to demonstrate the following: that FMHS students could not only effectively utilize PBL to leam, but also illustrate the effectiveness of PBL in covering related content. One assumed that this would help to alleviate FMHS faculty anxieties and doubts about this approach to teaching and learning. Chapter 3 then reviews benefits and areas needing further development related to PBL from the users ${ }^{2}$ perspective. It attempts to highlight the worth of PBL in the respective context. Data were collected, using a questionnaire in English and Arabic to study perspectives on PBL from both the faculty and students involved. This was done to inform any interested parties especially skeptical faculty, on the users" views regarding $\mathrm{PBL}$. It also highlights how $\mathrm{PBL}$ can contribute to improving the quality of learning for the students by identifying deficiencies in every day practice. Chapter 4 addresses the question whether evaluation by students is comparable te chatuation "by 'tutors. Further, how self-evaluation, compares with students" respective test results. During the undergraduate medical curriculum, how useful would selfevaluation be to the students' own progress and development? Self-evaluation which helps students in general appraisal is viewed as essential competence skills for every medical doctor, in their professional career. Chapter 5, focuses on an analysis of group dynamios dimensions. PBL requires co-operative group learning. How would UAE, FMHS students who had no previous experience of working in groups, view and cope with learning in small groups? Implenentation of PBL resulted in an opportunity to
investigate the identified areas further. Curricula concerns with the students moving
from pre-university education in Arbic to from pre-university education in Arabic to medical education and training in English were highlighted in the FMHS curricular revision of 1991. Various concerns with English language, and the UAE, FMHS students were further highlighted in studies identified earlier. In chapter 6 , using well respected qualitative methodologies developed in the 1950s, an analysis of students' facility with the English language and PBL group interaction was undertaken. This would hopefully highlight more clearly the type of problem(s) students experienced in relation to the second language, during 
PBL interactions. The summary and conclusion discuss the main findings overall, and demonstrate the issues and lessons learnt from a cautious introduction. Based on the study findings, recommendations are made in relation to possible areas for curricula revision. Implications for education are highlighted and suggestions are made regarding areas for future investigations. 
Table 1

In the (ITMM), The Title of the Problems, Themes and the Areas Emphasized

Problem Theme Areas Emphasized

1. Suhail and his Health Care

Health Care System

- Organization and function of health care delivery system

- Principles of "Health for all"

- Roles of different health professionals

- Presentation of health problems to the physician

2. Sayed Ahmed and his

environment

3. Rashida's dilemma

Environment and Health

- Environmental factors in relation to Health

- Prevention of disease due to environmental factors

- Traditional medicinal practices in the UAE

- Advantages and Disadvantages of alternative medicine

- Medical Ethics and Islamic Shariah in practice of Medicine

- Regular health check up

- Effect of chronic illness on individuals and members of the family.

5. Vaccination for Infectious Diseases Ayesha
6. Health problems in
Prevention and Health Promotion Berashi

- Transmission of Infectious diseases

- Prevention of transmission of infectious diseases

- Principles of health promotion which encompass health education

- Prevention and health protection. 
Table 2

Steps involved in the PBL tutorial process at FMHS, UAE University

1. Clarify terms in the problem description which are unclear

2. Identify the issues to be discussed categorising them into biological, behavioural, population, ethical, critical appraisal or any other identified heading acceptable to the group

3. Analyze these issues using prior knowledge

4. Formulate learning goals

5. Attempt to fill in the gaps in knowledge through individual study. Collect information from varied resources.

6. Share findings with the group, and try to integrate the knowledge acquired.

7. Evaluate self, peers and tutors, informally after each session, and formaliy on the last session per theme.

8. Evaluate the PBL tutorial process and the theme as in 7 above. 
Figure 1

Medical education areas the thesis addresses at the United Arab Emirates University

\begin{tabular}{|c|c|c|}
\hline Rescarch Question or Issues & Related Study Area & $\begin{array}{l}\text { Aspect of the } \\
\text { Innovation dealt } \\
\text { with }\end{array}$ \\
\hline Backgromind to the Study & $\begin{array}{l}\text { Presentation of Information } \\
\text { leading to the overall } \\
\text { investigation. }\end{array}$ & $\begin{array}{l}\text { Preliminary } \\
\text { Discussion }\end{array}$ \\
\hline $\begin{array}{l}\text { Q 1- Given a problem could the students } \\
\text { comprehensively identify leaming issues } \\
\text { related to the theme objectives identified } \\
\text { by faculty? } \\
\text { Q 2- What were unexpected learning issues } \\
\text { the students identified? }\end{array}$ & $\begin{array}{l}\text { Study } 1 \text { (Chapte } 2 \text { ) } \\
\text { Effectiveness of problems } \\
\text { wed in PBL. }\end{array}$ & $\begin{array}{l}\text { Providing a protected } \\
\text { environment, in } \\
\text { which to test ideas. }\end{array}$ \\
\hline $\begin{array}{l}\text { Q In view of skepticism expressed by } \\
\text { faculty staff regarding PBL, what were the } \\
\text { perceptions of turors and students involved } \\
\text { in the PBL programme? }\end{array}$ & $\begin{array}{l}\text { Study 2. (Chapter } 3 \text { ) } \\
\text { A review of PBL over fiwe } \\
\text { Whemes perceptions of } \\
\text { students and whors at the } \\
\text { UAE Unwersily. }\end{array}$ & $\begin{array}{l}\text { Minimization of } \\
\text { threat and By- } \\
\text { passing departmental } \\
\text { power bases. }\end{array}$ \\
\hline $\begin{array}{l}\text { Q 1- What were the differences between } \\
\text { self- and tutor evaluations of student } \\
\text { performance during PBL tutorials? } \\
\text { Q 2-How did students perceive the process } \\
\text { self-assessment and how did self: } \\
\text { evaluation compare with test results? }\end{array}$ & $\begin{array}{l}\text { Study } 3 \text {. (Chapter } 4 \text { ) } \\
\text { Self and tutov evaluations in } \\
\text { problem-based learning } \\
\text { tulorials: is there a } \\
\text { retationship? }\end{array}$ & $\begin{array}{l}\text { Providing a protected } \\
\text { environment, in } \\
\text { which to test ideas. }\end{array}$ \\
\hline $\begin{array}{l}\text { Q - What were the most important and } \\
\text { east important sub-clements of group } \\
\text { dynamics perceived by tutors and students } \\
\text { n PBL groups? } \\
\text { 2- What were the differing perceptions } \\
\text { "group dymarnics al by students from one } \\
\text { heme to another } \\
\text { between nate and lematle students } \\
\text { agarding perceptions of group dynamics } \\
\text { ithin PBL groups? }\end{array}$ & $\begin{array}{l}\text { Siudy } 4 \text {. (Chapter } 5 \text { ) } \\
\text { Perceptions of group } \\
\text { dynamics in PBL learning } \\
\text { sexsions: a time to reflect on } \\
\text { group issues. }\end{array}$ & $\begin{array}{l}\text { Offering an } \\
\text { innovative approach } \\
\text { to learning }\end{array}$ \\
\hline $\begin{array}{l}\text { 1- How do Arabic students of dinering } \\
\text { nglish language proficiency levels } \\
\text { teract in PBL groups? } \\
\text { 2. What factors influence English } \\
\text { ngugage proficiency (TOEFL resulis) and } \\
\text { the same fawtors influence PBL group } \\
\text { nntributions? }\end{array}$ & $\begin{array}{l}\text { Study } 5 \text {. (Chapter } 6 \text { ) } \\
\text { Facilio with the Engtish } \\
\text { Language and PBL group } \\
\text { interactions. Findings from } \\
\text { an Arabic Sething. }\end{array}$ & $\begin{array}{l}\text { Comfirming or } \\
\text { refuting numours of } \\
\text { importance to student } \\
\text { education }\end{array}$ \\
\hline verall results of investigations. & Summary and Conclusion & $\begin{array}{l}\text { Study findings, } \\
\text { lessons learnt, } \\
\text { recommendations and } \\
\text { areas for future } \\
\text { investigations. }\end{array}$ \\
\hline
\end{tabular}




\section{References}

1. Abdulrazzaq, Y.M. \& Qayed, K.I. (1991). A study of atitudes of the foundation staff of a new medical faculty to problem-based leaming. Medical reacher, $13,28 /-288$.

2. Association of American Medical College. (1984). Physicians for the Twenthror Century. Washington. DC.

3. Coulson, R.L. \& Osbome, C.E. (1984). Insuring Curricular Content in a Student-Direcied Problem-Based Leaming Program. In: H.G. Schmid \& M.L. De Volder (Eds.). Tulorids in Problem-Based Leaning: A New Direchons in Teaching the Hoalh Professions. (pp 225-229). Van Gorcum Assen: Maastricht, The Netherlands.

4. Das, M., Lanphear, J.H. \& Ja'afar, R. (1994). Faculty Evaluation of Educational Strategies in Medical Schools. Medical Teacher 16,4,355.361.

5. Das, M., Murdoch C.J. \& Mpofu, D (1995). Problem.Based Leaming in the Faculty of Medicine and Health Sciences, United Arab Enirates University. Emirates Medical Woumal 13, 23,5-246.

6. Das, M., Murdoch, J.C., Mpofu, D. \& Benner, A. (1996). The Role of Peer- and Self-assessment during Experiential Leaming in Community Settings. Education for Heath, 9, 2, 239 249.

7. Dolmans, D. (1994). How stadents Leam in Problen-Based Curricuhan . Universitame Pers Maastrichi, The Netherlands.

8. Fulop, T. (1985). Heal th Personnel for tomorrow; the great challenge of the health for all movement. WHO. WRP/HMD/NF.4. Regionat Office for ihe Western Pacific 27 March 1985.

9. Gallagher, E.B. (1993). Cumicular Goals and Student Aspirations in new Arab Medical College. In: P. Conrad \& E. Gallagher (Eds.). Healh Care in Developing Countries. (pp 134153). Philadelphia, Temple University Press.

10. Gardner, W.E. (1995). Developing a Quality Teaching Force for the United Arab Enirates: mission improbable. foumal of Education for Teaching, 21, 3, 289-301

11. Hatrison, A., Glasgow, N. \& Townsend, A. (1996). Communications skils training early in the medical curriculum: the United Arab Emirates experience. Medical Teacher. 18, 35-41.

12. Kantrowitz, M., Kaulman, A., Menmin, S., Fulop, T. \& Guilbert, J.J. (1987). Imovative Tracks at Established hustitutions for the Education of Healh Personnel Geneva: World Health Organisation, Offet Publication No 101.

13. Lanphear, J. (1991). The Evolution of Medical Education In the United Arab Emirates University: A New Curriculum For A New Era. Emmates Medical Jourhat, 9, 214-224.

14. Magroub, M., E. (1994). Snudies in Commwity-Based Education. Universitaire Drukkerij Maastricht, The Netherlands.

15. Majoor, G.D., Schmidt, H.G., Snellen-Ballendog, H.A.M., Moust, J.H.C., Stalen hoef-Halling. B. (1990). Construction of Problems for Problem-Based Learning. In : Z.M. Nooman, H.G. Schmid, \& E.S.Ezzat. (Eds). Imovation im Medical Edwcation: An Evalnation of its Present Stans (pp. 114-122) New York: Springer Publishing.

16. Mpofu, D.J.S., Schmidt, H.G., Das, M., Lanphear, J. de Dum, E. (1998). A Review of Problembased Learning: Perceptions of Students and Tutors an the United Arab Emirates Uniwersity. Educations for Healh $, 1 /, 2,203-213$.

17. Mpofu, D.J.S., Das, M. Stewart, T., Dunn, IE. \& Schmid, T. (1998). Perceptions of groulj dynamics in problem-based learning sessions: a time to relled on group issues. Medical Teacher. $20,5,421-427$.

18. Rangachari, P. K. \& Crankshaw, D.J (1.992). Formative evaluation in a lutoral based course. In: Procedings of the $5^{\text {th }}$ Instructional Show and Tell for Onario Unwersties, (pp 125 -130). University of Guelph, Guelph, ON.

19. Swadi, H. (1997). The impact of primary language on the perfomance of nedical undergraduates in communication skills. Medical Teacher, 19, 4.270-274.

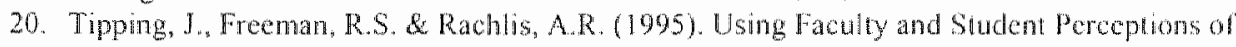
Group Dynamics to Develop Recommendations for PBL Iraining. Acadentc Medicine, 70. 11. $1050-1052$

21. World Federation for Medical Education (1989). The Edinburgh Declaration. Annals of Commundy Orened Medical Education. 2. 11/-1/3. 


\title{
Effectiveness of problems used in problem-based learning
}

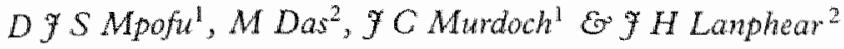 \\ Departments of 'Family Medicine and ${ }^{2}$ Medical Edwotion, Faculty of Medicine and Heath Sciences, \\ Urited Arab Erairates Universing, Al-Ain, Abu-Dhabt, United Arab Emirates
}

\section{SUMMARY}

Where problem-based learning (PBL) is the man method used in medical curricula, the literature suggests that it is crucial that the problems used arce offective in facilitating students to identify relevant leaming issues. These learning issues guide the sudents" studying. The present investigation explores the extent to which students identify relevant issues following exposure to prepared paper problems. In the preparatory year, in an Introduction to Medicine module, four groups of students were exposed to six themes (Health Care System, Enviromment and Health, Alternative and Islanic Medicine, Chronic Illness, Infectious Diseases, and Prewention and Heath Promotion). Each group had two facilimators per theme. Hawing discussed the prepared problems, the students identifed learning issues which were collected for the purpose of the study. Two content experts, using a Likert scale, analysed la arning issues for the oncordance to steff abjecrives per theme. Kappa coefficients were computed for the six PBL themes in order to assess inter-rater agrewent. lewang issues bomifed as having no rellationship to theme objectives were further analysed for then relevence to theme objectives. No obiccive was cotally omitrod by any student group. There was a $100 \%$ concordance of obpecives to learnm ing issues demonstrated over four theries. The relatronship of learning issurs to theme objectives ranged from 55-85\% in the theme on health care sytem, and $73-94 \%$ in the theme on enviroment and heath. IrTevan learning issues were identified in the first two PBL themes addressed. Kappra coefficients over the six PBL themes varied from 04910082 .

\section{Keywords}

*Education, medical, undergraduate; learning; "problem-based learning; srudents medical * psycholog; Unind Arab Frivates
The United Arab Eninates (UAE) Unitersity medical curriculum is a year progranme, the preparatory year is the furst year of education and hraning. Problem Based learning (PBL) is used as the teaching and learning strategy in the Introduction to Medicine module of the First (preparatory) counst, which nuns throughout the academic year.

The kind of problem that wodical students use in the problem-based approsch in the Preparatory Year can be illustrated by this example

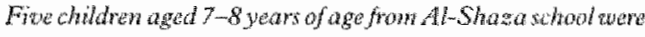

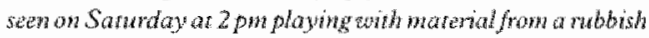
heap. Sowne appeared to be earing their sandwhth afrer playing on the wabish dump. The heap af mobjish and foll of dirry cans, bonles, old jood, all sorts of paper and sane fhes.

Alt wh his foot wh a dirry meral wire and" was imbediately must to Emergetwy department of the hospital. Alt

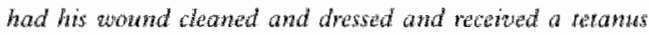
injection.

The nex moming Mohomoned and Jamal (Ali's friends)

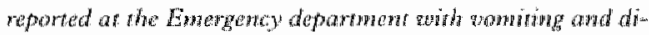

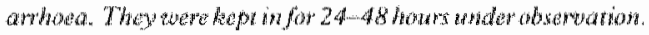

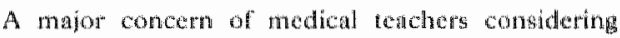
PBL is that students will not comprathenty address essuntial learming mateval (Coubon os orme 1.984 ; Waternon a coolcy 1985 , Severgl reports hawe indicated that problem ases should lend sudents townd the learning objectives dfetermined by stall members (Shahabudin 1987; Blumbera es al. 1900; Matoor at al. 1900; Domans a al 1993). Studues by Coulson \& Osborne (1984) and later by Dolmans (1994) indicate that scudnots identify approximaty $60^{\text {th }}$ of the lam ing intended by saff.

\section{AIMS OF THE STUDY}

The purpose of the study was twofold. First, to idencify whether, given a problem, the suckere could comprehensively idenery leatring issucs related to the theme 
objectires identified by stafl. This was assessed by the degree of congruence bewen staff objectives and student generated learning issues. Second, to review

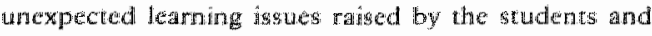
atumpt to contegorize then.

\section{Problem-bused learning - the process}

In PBL as organized at the UAE University, eight to 10 students formed a therial group. Each group had two group facilitators who rematined with the same group for each theme. Following discussion of each problem trigger, sudents identified lexming joswes which were written on flip chatr. The group categorized the learning issues into the following parameters: biological issues; behavioural/educational issucs; populanon issuesiz ethical isues; and critical appraisal issues. The group, wh the aid of the facilitator, divided the trask of obtuning the information amongst themsel $\mathrm{w} / \mathrm{es}$. Ideniffation of appropriate leaming resources followed and included: ibrary materials; computer searching; video materials; expeniences in skillo laboratory; hospiwats and clinics; and use of faculty experts 10 gain a wariety of infomation. Fivaluation concluded the group sessions where the facilitator not only encouraged selfevaluation by each group nember, but also encouraged peer and student evaluation of the tutor by all pupils inwolved.

The Introducton to Medicine module themes weren Health Care System (HCS); Enviromment and Health (EVH); Alternative and Islamic Medicine (AM); Chronic Illness (CHI); Infectious Diseases (IND), and Prevention and Health Promation (PHP).

An example of a problem trigger from the theme HCS. Almed Hassan wisued the local health cetwe wath his 7-yzar-ald som Swhat. Swhat had a common

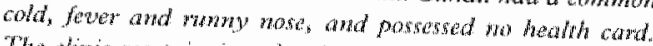

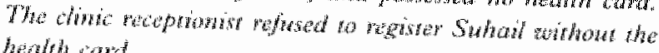
hath wath.

The HCS objetive was that students should be able to describe and start to understand the organization of

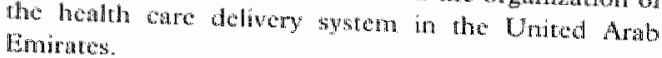

An example of a student group ${ }^{*}$ teaming goal derived fom learning issues identified following aposute to the abowe Hos trigger. What is the inportance, purpose and tunction of health cards in the
UAE?

(a) the irdividuals:

(b) to a health centre organgation; and

(c) ro the Ministry of Health.
The problem triggers were prepared to be ws real as possible and were intended to reflect local style, tradton, culture and enorday experiences. The problem riggers relating to whe theme on halth care system were prepered from fue theme oblecrives.

\section{METHOD}

Each theme had a set of related problem riggers which students workad on over a 4 wedk period of 16 hours duration. Students were offered the problem trigger for the frst the during a PBL group session. Learning issucs generated from each session were collected from all groups. The experts were briefed about the theme, the faculty objectives and the process of evaluation. At the end of each theme the faculty objectives, leaming issues identified by the studens and evaluation forms were sent the the respective experts. For each theme experts consisted of a clinician who was a specialist in the field rellated to the theme and one senior staff nember. Twelwe experts participated in this study all of whom independenty rewewed learning issues generated by students in each theme. For example, in the theme on infectious diseases, a clinical specialist in the feld of infectious atiseases and a professor in Communiry Medicine analysed the material. The experts were not involved as facilitators in the module teaching and they used a three-point Likert scale to assess the extent to which the leaming issues rased in each theme strongly related to the theme objective(s); had a moderate relationship to theme objective(s); or had only slight relationship theme objective(s). Experts also indicated learning issues which had no relationship to the theme objectives. These learning is wes were further assessed on a three-point Likert scale as to whether they were totally imelewant; neutral; or relewant to the theme oblective(s). This was done by smply comparing icaming isswes to theme objectives.

\section{STATISTICAL ANALYSIS}

The dare we coded and processed on an IBM ${ }^{\circ C}$ compatible computer using the Statistical Packages fot Socual Solences (Norusis 1992). Each expert's responses were entered into the computer and percent. ages of leaning issues identified as related to faculty obpetwes por theme were calculated. Percentage of cathing issues unrelated to objectives and learning iscalculated. Kapha to indwidual themes were also comparisons made of restonents wore computed and 


\section{RESULTS}

The toral number of learning issues generated for each theme by all four student groups were as follows: $\mathrm{HCS}=232 ; \quad \mathbb{E V H}=149 ; \quad \mathrm{AIM}=122 ;$ CHI $=93 ;$ TND $=159 ; \mathrm{PHP}=130$. There was $100 \%$ concordance of student generated leaming issues to theme objectives in retation to the themes AM, CHI, IND and PMP. These four themes had objectives ranging from one to four per theme. In the thene on health care system, $125 \%$ of those learning issues idencified as having no relationship to theme objectives by experts were further judged as totally inelewant to the theme objectives. These leaning issues related to diagnosis, investigations and treament; biological issues; and areas related to sociologicalpsychologica perspectives of health.

In the theme EVH, leaming issues identified as having a relationship to theme objectives ranged from $73-94 \%$ among different student groups. Of those leaming issues identified as having too telationship to theme objectives, $3 \%$ were further judged as totally ir relevant to the faculty objectives related to the theme on enwiromment and health. These related to investigations and treatment; biological issues; and areas trelating to sudents" own experiences and interest with environmont and health issues. No objective was judged as totally missed out by any student group, although whin the themes HCS and $\mathrm{EVH}$ certain objectives received superficial attention.

The level of intermater agreement for each pair of raters in the various themes ranged from $73.9 \%$ to $983 \%$. Since these percentages may have over-estimated the true inter-rater agreement due to agreement based on chance alone, Kappa coefficients were computed for the six themes, for each pair of raters in order to assess inter-rater reliabilly (Table 1). Here Kappa coeffictents take into account the expected proportion of agreament due to chance alone (Landis 8 Koch 1977 , and the $\mathbb{K}$ appa coefficients waried from 0 -4:9 100.2

\section{DISCUSSION}

This study inwestigates the extent to which students are able ro identify relevant learning issues during exposure to paper-based problems prepared by staff in a problem-based curriculum. It is important to note the limitations of the study before discussing the resulrs. One of the inherent limitations of such qualitative educational research is the influence of subjectivity. Efforts were made to make the narure of evaluation by experts as obiccrive as possible and two experts were involwed for exaluation of each theme to minimize subjectivity. Furthermore, Kappa coefficients which assess the agrement or reliability of experts were computed. This in effect measured the proportion of learning issues experts classified into the same category using the defined Likert scalc. The resultant range from 0.4910082 indicated a moderate to substantial level of agreennent between the rwo experts in each theme (Everite 1994).

The degree of concordance between learning issues and theme objectives varied from $55 \% 10100 \%$ (average $91.4 \%$ in different themes and among the four student groups. The perentage of overlap between student learning issues and staff objectives for HCS was $55 \%$ to $85 \%$ (average $7625 \%$ ). For the theme EVH there was a 73 to $94 \%$ (average $8725 \%$ ) overlap. The last four themes were more eftectively covered, with $100 \%$ concordance of learning issues to staff objectives. Dolmans (1994) found the degree of overlap in her study to vary from $27.7 \%$ to $100 \%$, with an saverage of $64.4 \%$. Furthermore, on average the tutorial groups failed to identify $7.4 \%$ of the objectives $(15 \%$ of the course objectives). In our study, at though no objective was completely onitted by any student group, the theme HCS had learning issues which were assessed as having little relationship to two objectives by both $\mathrm{ex}$ perts. One of the reasons for the superficial address of an objective by FMT-1S students may have been lack of experience of leaming using PBH. at the beginning of the rnedical curriculum. On the other hand, the qualiry

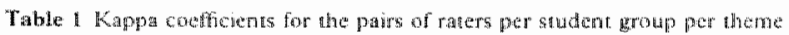

\begin{tabular}{|c|c|c|c|c|c|c|}
\hline & $\begin{array}{l}\text { Health ware } \\
\text { system }\end{array}$ & $\begin{array}{l}\text { Enversonment } \\
\text { and hetalen }\end{array}$ & 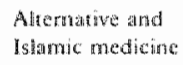 & Chronto ilnews & $\begin{array}{l}\text { frofections } \\
\text { disenses }\end{array}$ & 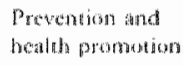 \\
\hline & & & & & & \\
\hline Group & $0 \% 9$ & 072 & 0.95 & 0606 & 061 & 0.50 \\
\hline Group 2 & 079 & 060 & 0.76 & 40 & inos & 0.70 \\
\hline Group 3 & 082 & 068 & 0.79 & 0.74 & $x$ & 0613 \\
\hline Group 4 & 005 & 078 & 0.72 & 0.62 & Sew & 0.78 \\
\hline
\end{tabular}


of the problems used may have simply falled to address particular learming objecuves.

As the acadernic year progressed the studants" PBL group discussions became more focused. Feediback from the facilitators both about their (students) contribution and the process of learning by discustion in PBL sessions could have further contributed to the changes noted in identification of learning issues for later PBI. themes. For the majority of the factitators this was the firs experience of conducting PBL tuto rials. A regula fallititor development programme was conducted after the implementation of PBL and a deailed turor guide was prepared by the planuers which identifed objectives to be covered and gave guidancer or learning areas to be focused on by the students. Discussion stessions were held by factilators and planners before and after PBL sessions for each theme. The discussion sesions were very useful in facilitating the PBL turorials and could have contribuled directly to the abily of the facilitatror in guiding the students to identity leaming issues. It has been reported that facilitators maly have a major rolle to play in factiating aspects of the PBI latining process. However, there are debates about the most beneficial role of the nutor (Motist al 1960, Davis ar al. 1992). Orn the other hand, other teports indicate the importance of a combination of factors to facilitate learning during PBL. These are indicated as activation of students prior knowledge; good quality problems; show of inrerest in the students by the tutor; a meaningful context; a wenllstructured student guide book; and suitable group functioning (Gijselaters \& Schmidt 1990).

The suggestion is, therefore, that investigations carried out in realistic settings such as oun study are prone to meliciple variables influencing the outcome. The re sults of this study suggest that the problems used were better structured for the lagr four PBL themes. Problem miggers used in AM, CMI NDD, PHP led students towards louning objuctivess detamined by the foculy. Studying owerlapping of faculty objoctives to the stu-

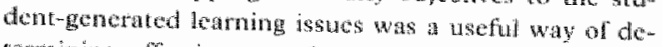
tarningug effechuncs of problem triggers in stimulating the students to identify learning isstos (Dolmans w. as. 1903: Shathatudin 1987)

The quality of problems used could have reill com tributed to idencification of irrelevant learning issues which wectited with the thenes HCS and EVH, especially consthering that the theme on HCS had fwo theme objectives, some of which were pery broad. An

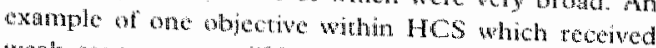
weat corerage was "Understand the importance and conomics of health planning". Mayoor et al (1990) sugeests that there is an ant to develop enective problens for PBL which requires tean effort, dedicated time aria rigour.

A number of studen-genarated issues were identified as unelated to the facuiry-deremined objectues. "This is not surprising as the process of PBL allows students to brainstom and identify issues they need to lem. Howewer, many such issues were further juged as acrually related to aspects of we theme at hand, and these extra issues were relevant in highlighting students thoughes at the beginning of the medical curriculum. It appears that students hope to find concrete factual answers to all medical queries. Thus they raise questions inke "what exacty is the correct treatment for a common cold?" or "is it always clear how to diagnose Illmess in a patient". A few of the learming josues identified by the students were very usetul for stimulating major debate among students. This was parricularly true in identifying behavioural, population and ethical issues. For example, students using prior knowledge questioned the usefulness of consulting a doctor for a common cold. Not only did they share experiences hare, but they inquired at local health centres about the frequancy of attendance by various age groups for "the common cold" and discussed the following: possible causes of the common cold; signs and symptoms related to the condition; the common remediss used at home; probable medical tratment; the local population's knowledge about aspects of the common cold; patients' rights to health care, and so wh. Most of the staff of the FMHS are expariates from warious parts of the world and probably missed the significance of some of the population, behavioural and ethical issues raised by the sudents. Thus, although experts identified few student-generated learning issues as unrelated to faculy objectives, the experience has prowed to be an eye-opener for staff and rodule planners. Comments from group facilirators indicated that studints discussions during followm group sessions demonstrated increashd assarmeness, self-directedness, and a degree of reflection on expericnces not consciously intended by module planners.

The stwdy ictentifies that by using well-structured papuer-based problems sudents could identify leaming issues related to faculty generated oblecrives. There is an implication that wery broad faculy objectives, combined with group and fichlitator mexperience could lewd ro problem riggars that were unable to direct the students to the incended leaming gods. Therefore, in order to reduce concern that students mat fall to ad dress essental leaming thaterial in the PBL corriculum not only should curriculum planners pay close attention to the construction of problem triggers from the defined objectives, but they shouk also encourage continuous 
suppor and monitoting of the faclinators and the PBL process.

\section{ACKNOWLEDGEMENTS}

The authors would like to thank Dr D Dolmans, Unim versity of Limburg, Mastriche, for her support and ideas generated from consulting her thesis For theit participation, feedback and encouragement with the sudy, curther thanks goes to all the srudents, seaft nembers and clinicians related to the FMHS, UAE University, in particular Prof E V Dunn.

\section{REFERENCES}

Blumberg P, Michare IA \& Zentz H $(1990)$ Roles of scudentgenemed leaming issues in problemubased learning. Teaching and Lianting in Medicine 2, $149-54$.

Coulson R L \& Osbone C E (1984) Insuntrg Curricular Connent in a Sudent-Dipected Problem Based Learning Program. In:

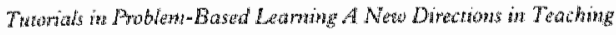
whe Hoalh Professons. (ed. by H G Schmide \& M L deVolder) pp. 225-9. Van Gorcum Assen, Mascriche, The Netherlands.

Davis. W $K$, Naim R, Paine Mi Anderson R $M$ \& Oh $M S$ (1092) Efects of expert and nonexpert facilitators in a course using problem-based learring. Atademic Nedicine 67, 470-4.

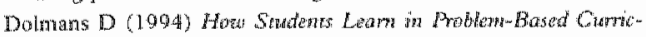
uhtw. Uniwersitaire Pers Massericht. The Netherlands.

Domans D H, Gijselaers W H, Suhnidt H G \& Van der Meer S B (1993) Probten effectuchess in a course using problem-based learning. Academic Modicine $68,2077.13$.

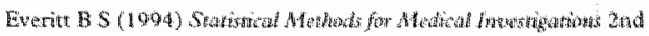

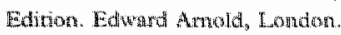

Gijsalars $\mathrm{H}$ \& Sohmol $\mathrm{H} \mathrm{O}$ (1990) Development and Eta-

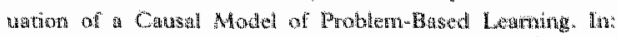

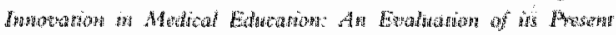

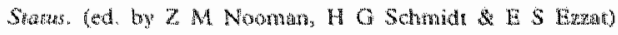
pp. 95-1 13. Springer Publishing Wew lork.

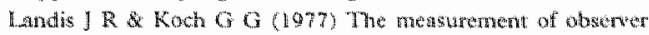

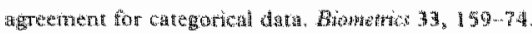

Majo or $G$, Schnidr H $G$, snethen-Eallewdor H A M, Moust I H C. StatenhoefHadling 13 (1990) Construction of Brobtems

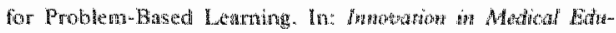

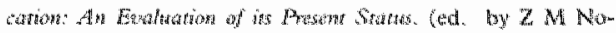
oman, H G Schmidr \& $\mathrm{S}$ Tzzan pp. 114-22. Springer I wblishing New York

Mous J HC de Grave W 5 \& Gigelaes W $\mathrm{H}(1990)$ The rut

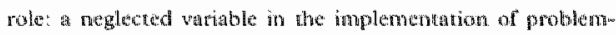

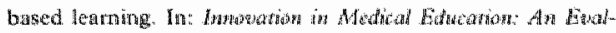

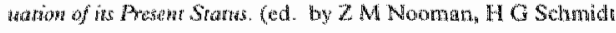
8. E S Ezat pp. 135-51. Springer Publishing, New york.

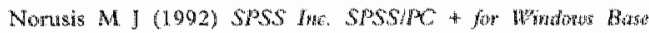

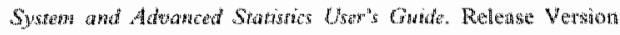
6.0. SPSS Inc. Chicago, Minois.

Shahabudin S H (1987) Content coverage in problem-based

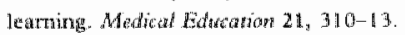

Watcrman R E Conley B (1985) Curriculun problems to

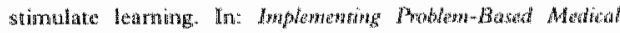
Edwconds. (ed. A Kaufrnan), pp. 150-8. Springer Publishing. New York.

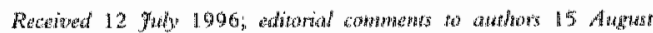

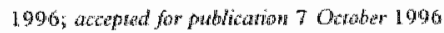




\title{
A Review of Problem-based Learning: Perceptions of Students and Tutors at the United Arab Emirates University
}

\author{
D. J. S. MPOFU , H. G. SCHMIDT ${ }^{2}$, M. DAS 3 , J. LANPHEAR ${ }^{3}$ \\ \& E. DUNN ${ }^{1}$ \\ 'Department of Family Medicine, United Arab Emirates University, \\ Al-Ain, United Arab Emirates, ${ }^{2}$ Department of Psychology, Maastricht \\ University, The Netherlands and ${ }^{3}$ Department of Medical Education. \\ United Arab Emirates University, Al-Ain. United Arab Emirates
}

\begin{abstract}
Problem-based Learning (PBL) is being adopred by medical swows the world over. Some PBL schools have thique culturat and student-rutor characteristics. These programmes need approprtate feedback on $P B L$. The present study focuses on perceptions of students and ators involwed in a new PBL programme. Data were collected in English and Arabic. Gender differences in students behaviour within groups were highlighted wh significant differences between males and females in wo areas. Siudents concens about PBL were related to communication in English and that certain aspects of the PBL themes were inadequately covered. The only significant difference between the students' and the Iutors' perceptions was in the first PBL theme. From the mors' perspective, students understood the various PBL elements except the critical appraisal aspect. The review has demonstrated the merits of the PBL programme. An evaluanan exercise would be a logical progression from the presens erercise.
\end{abstract}

\section{Introduction}

At the Faculty of Medicine and Health Sciences (FMHS) in the United Arab Emirates (UAE) University, the preparatory year (the first year of medical education) uses problem-based learning (PBL) as one of the approaches 10 teaching and learning. PBL is used in the Introcuction to Medicine Module (ITMM) which is to provide students with insight into the health care system of 
the UAE, the sociowculural, psychological and environmental factors which affect health, disease prevention and health promotion. This module includes the Health Care System, Alternative and Islamic Medicine. Family Study, Infectious Diseases, and Prevention and Health Promotion. Each theme constituted a complete unit of study with clearly defined objectives.

The Medical Faculty was established in 1986. Its curriculum uses a variety of teaching and learning methods. Problem-based leaming, originally identifed as one of the key principles, was not introduced until 1994. In 1991. a study revealed that only seven out of eighteen academics interviewed understood PBL. and a further five colleagues were openly hostille to this approach (Abdulrazzaq \& Qayed, 1991).

Following active participation by the FMHS in the World Summit on Medical Education in Edinburgh in 1993, two academics from McMaster University were invited to the Medical School to hold an intensive workshop on PBL. During the following year curriculum planning included training of library and support staff, staff development, and development of student orientation measures. These aspects of PBL were reviewed and developed annually by the Medical Education Department. In reviewing the various $\mathrm{PBL}$ models the Mastricht model (Schmidt, 1993) was fawoured and introduced with slight modifications (Das el al., 1995).

\section{Student Orientation and Tutor Training}

Twelve hours were devoled to acquainting students with some of the key elements of the PBL programme. The principles, the seven steps, the tutorial sessions, group interaction, information management skills, assessment and evaluation of $\mathrm{PBL}$ group sessions were dealt with during this period. Use of videos, role play and practice of the PBL process were part of the orientation (Das et a.. 1995). Following library orientation, the students practised their newly acquired library skills as part of the induction process. Fifteen tutors were involved in the Introduction to Medicine Module. Each tutor participated in at least two sometimes three PBL themes. The tutors were from eight different specialties: Family Medicine, Community Medicine, Phamacology. Anatomy. Psychiaty, Internal Medicine, Andesthesia and Medical Education. Only five of the fifteen tutors had any previous experience of PBL. The tutors' workshops covered similar ground to that in the students" orientation. The role of the group tutor to facilitate and not to lecture was emphasized, as well as the goals of PBL. Tators practised acting as PBL tutor, scribe and group member. Mini inforPBL thene with module coordinat two hours were held before and afrer each particular theme. Informal feedback sessions by tutors who were involvad in a each PBL session. Formal fedback sessions by each group were scheduled after at the and of each PBL theme (Das ef al. 1996). 


\section{Problem-based Learning at UAE University}

Six to ten students formed a tutorial group. Each group had either one or two tutors. who remained with the same group for a specific theme. It is important to note that for cultural and religious reasons, male and female students were separated for all teaching and learning purposes. In the present study there were three groups of six to seven female students and one group of seven male students. Following discussion of each problem trigger, students identified learning issues which were written on a flip chart. The groups categorized the learning issues as biological; behavioural; community; ethical; and critical appraisal issues. With the aid of their tutor the students divided the task of obtaining the requisite information amongst themselves. Identification of appropriate learning resources followed, including library materials, computer search, video materials, exercises in the skills laboratory, experiences in hospitals and clinics, and the use of experts to gain a variety of information. Follow-on PBL sessions commenced with a review and discussion of areas researched during self sludy. This report-back phase was undertaken before progressing to the next PBL thematic trigger. One hundred and forty hours were dedicated to the ITMM over one academic year. Just under $50 \%$ of the module time was dedicated to PBL tutorials which were always followed by self-directed study. Twenty per cent of the module time was dedicated to lectures, $20 \%$ to clinical and field work sessions, and $10 \%$ of the time was reserved for project work (Das et at, 1995).

\section{Assessment}

The ITMM module used the assessment system of the FMHS: Modified Essay Questions, Multiple Choice Questions and Objective Structured Clinical Examinations.

\section{Aims of the Study}

Anecdotal evidence suggested scepticism amongst faculiy staff regarding the benefits of PBL. In view of the earlier expressions of hostility towards PBL and the novelty of the PBL programme. this study sought to identify tutors" and siudents" perceptions of $\mathrm{PBL}$.

\section{Method}

In June 1995 a pilot questionnaire, adapted from Majoor et at. 11990$)$, was tested on a group of six students who had completed a year of PBL. At he FMHS. students. whose forst language is Arabic. use English as the language of 
instruction. Comments by the student pilot group indicated that the investigators might receive a more honest response from First Year students if the questions were in Arabic. The students" questionnaire (Table I) was, therefore, translated into Arabic and later back into English, in order to check for accuracy.

All PBL wutors were asked to complete a tutor questionnaire in relation to each theme. The questionnaire had also been used wh three tutors. Although various comments were made, it was agreed that the questionnaire was suitable for completion by tutors (Table 1).

At the end of each of five themes, the students completed the Arabic questionnaire, focusing on the theme they had just completed. This resulted in 35 questionnaires from the seven male students and 100 questionnaires from the 20 female students (Table 3). The questionnaire consisted of Likert-type items. For each item they were asked to indicate (1) full agreement, (2) agreement, (3) neutrality, (4) disagreement, (5) full disagreement. Space was provided for comments. For the initial three PBL themes each group had two group tutors, an expert in the topic of the theme and another academic. For the last fwo themes each group had only one tutor.

The data were entered into ACCESS and then imported into the Statistical Packages for Social Sciences (SPSS) for analysis (Norusis, 1992). The mean ratings and standard deviations of items over the five themes were calculated. The total scores were calculated by adding up individual item scores. It is important to note that for comparison of tutor versus student scores only items appearing in both the student and tutor questionnaire were included (Table 2) Only the following items were used: Q1, Q4, Q5, Q6, Q7, Q8, Q9, Q10 and Q11 (Table 1). Correlation coefficients were calculated, and differences between tutor and student responses were tested using a two-tailed significance test. The t-tesi was used in analysing student versus tutor responses and male versus female
student responses

\section{Results}

At the beginning of the academic year $1995 / 96$ there were 32 students in the preparatory course. However. two male and three female students dropped out during the course of the year. Therefore, the student group for analysis consisted of 27 students. Over the five PBL themes 135 student responses were collected. All the turors, except one member who left the FMHS during the academic year. completed the questionnatres, atotal of 31 tutor forms.

\section{Thtors" and Students" Views}

From PBL. Theme One to Theme Five there wits growing consensus amongst varied from aspects of $\mathrm{PBL}$ as the year progressed. Student responses, however, varied from theme to theme. The greatest consensus was for the theme on Healu? 


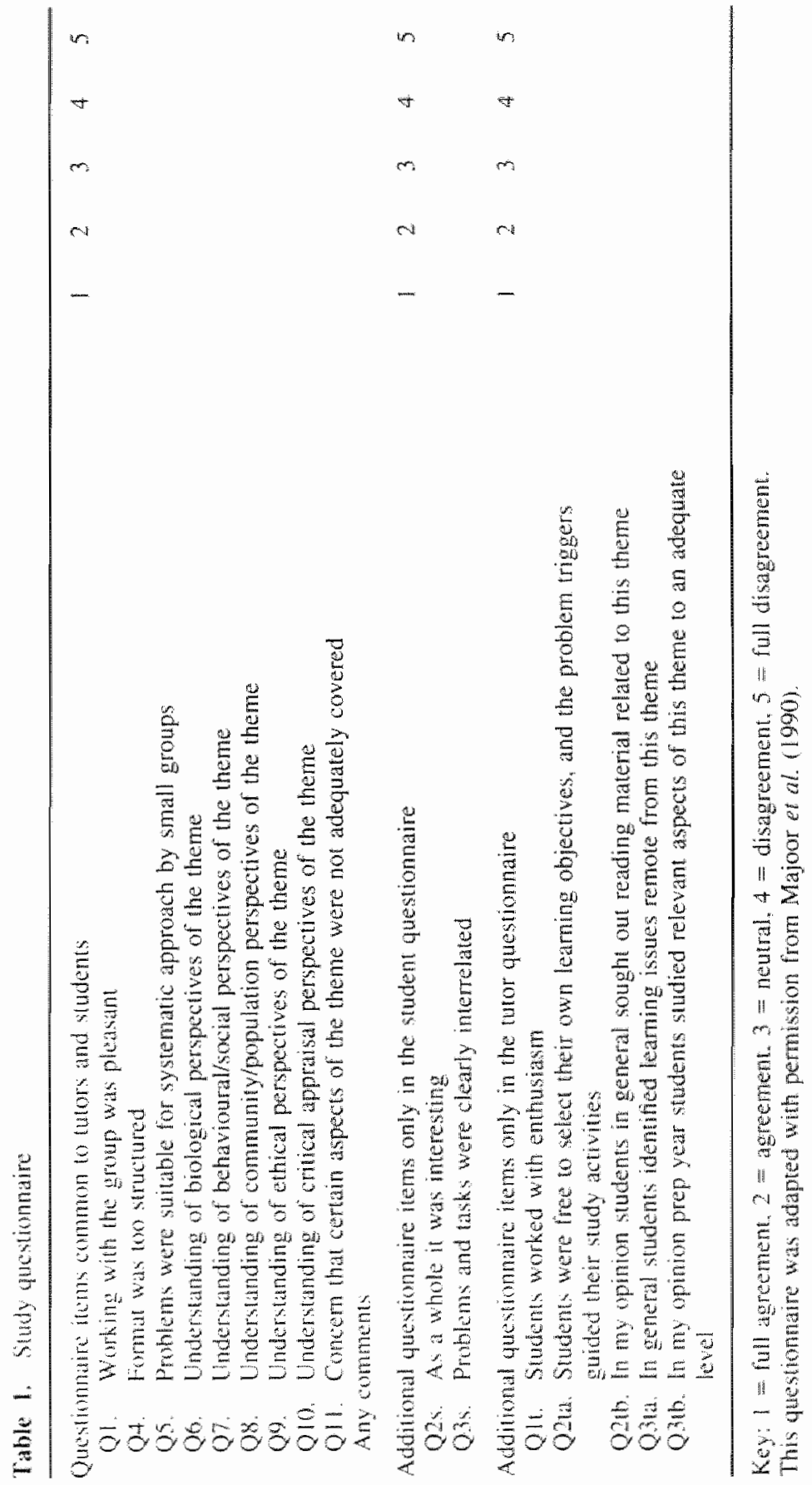


Table 2. Tutors" and sudents" aggregate responses across the five PBL themes

\begin{tabular}{|c|c|c|c|c|}
\hline \multirow[b]{2}{*}{ Theme title } & \multicolumn{2}{|c|}{ Number } & \multicolumn{2}{|c|}{ Mean $(S D)$} \\
\hline & Tutors & Situdents & Tutors & Students \\
\hline Health Care System & 8 & 27 & $19.75(6.78)^{6}$ & $15.66(3.40)^{\circ}$ \\
\hline \multicolumn{5}{|l|}{ Altemative and } \\
\hline $\begin{array}{l}\text { Fistamic Medicme } \\
\text { Family Sidudy }\end{array}$ & $\begin{array}{l}7 \\
8\end{array}$ & $\begin{array}{l}27 \\
27\end{array}$ & $\begin{array}{l}16.33(4.37) \\
15.57(3.80)\end{array}$ & $\begin{array}{l}14.40(6.29) \\
15.22(5.53)\end{array}$ \\
\hline Infectious Diseases & 4 & 27 & $15.50(2.28)$ & $15.18(4.17)$ \\
\hline \multicolumn{5}{|l|}{ Prevention and } \\
\hline Health Promotion & 4 & 27 & $14.00(1.29)$ & $15.88(5.61)$ \\
\hline
\end{tabular}

$a_{t}=3.15, \mathrm{df}=33, p<0.003$.

All other differences were not significant.

Care System and the least consensus for the Alternative and Islamic Medicine as shown by standard deviations (Table 2).

The only significant difference between tutors" and students ' responses related to Health Care System $(p<0.003)$. From the 31 tutor responses over the five PBL themes, $90.3 \%$ of the tutors perceived that the students had worked with enthusiasm. Eighty-seven per cent of the tutors felt that the students learning issues matched the objectives for the themes. However, $34.8 \%$ of tutors indicated that the students identified further learning issues not directly related to the themes. Only $54.8 \%$ of tutors felt that the students had sought out relevant reading material. Tutors" comments echoed the students' open-ended comments, suggesting that English was a contributory factor. At least $50 \%$ of the tutors also indicated that English appeared to limit some students' participation in group
activities.

\section{Male Versus Female Perspectives of PBL}

For all the items, except for items 5, 10 and 11, male students recorded lower mean values than their female counterparts, thus demonstrating higher agreement with the questionnaire items (Table 3). In Item $2 \mathrm{~s}$ (PBL being interesting) and them 8 (recognition of the importance of covering community perspectives in the (Table 3). When comparing responses a siffere between male and female scores positive to having two tutors than a single tutor. There was noups were more preference within the male group.

\section{Discussion}

The instrument used for the review proved to be valuable for gathering general information on the merits of a new PBL programme. Question Q2ta (Table 1) 
Table 3. Male students" versus femalte students' views of PBI across all five module themes

\begin{tabular}{lcc}
\hline & $\begin{array}{c}\text { Total male } \\
\text { questionnaires }(n=35) \\
\text { Mean }(S D)\end{array}$ & $\begin{array}{c}\text { Total femate } \\
\text { questionanares }(n=100) \\
\text { Mean }(S D)\end{array}$ \\
\hline Q1 & $1.40(0.50)$ & $1.63(0.77)$ \\
Q25 & $1.40(0.50)$ & $1.85(0.80)$ \\
Q3s & $1.83(0.71)$ & $2.06(0.83)$ \\
Q4 & $2.14(0.81)$ & $2.18(0.83)$ \\
Q5 & $1.69(0.80)$ & $1.55(0.77)$ \\
Q6 & $1.86(0.69)$ & $1.99(0.88)$ \\
Q7 & $1.63(0.60)$ & $1.84(0.84)$ \\
Q8 & $1.49(0.56)$ & $1.84(0.91)$ \\
Q9 & $1.54(0.66)$ & $1.68(0.91)$ \\
Q10 & $2.00(0.80)$ & $2.00(0.96)$ \\
Q11 & $2.91(1.12)$ & $2.85(1.06)$ \\
\hline
\end{tabular}

1 = Full agreement, $5=$ Full disagreement.

All differences were not significant, except

Q2s "As a whole it was interesting" $t=3.13, \quad \mathrm{df}=133, \quad p<0.002$

$\mathrm{QB}^{b}$ 'I recognized the importance of

covering community/population

perspectives within the theme":

$t=2.17, \quad$ df $=133, \quad p<0.008$.

had to be withdrawn from the discussion as it did not permit precise interpretation. Open comments provided the 'icing on the calke' to perceptions and some have been used in the present discussion.

\section{Students" Versus Tutors" Views}

The students recorded a varied response to PBL. They unjoyed working in groups and found PBL interesting. The tutors also enjoyed PBL. However, tulors and students demonstrated statistically significant differences in their perceptions of the very first theme: Health Care System. Anecdotal evidence suggested that the students had only experienced didactic teaching methods up to this slage and had rarely engaged in group activities. A wo-week orientation may have been insufficient as an introduction to PBL. The benefits of a well planned period of familiarization have been highlighted by Engel (1992). As for the students" concern that some aspects of the curriculum may not have been covered in all the five PBL themes, other studies have confirmed that an inability to identify knowledge deficiencies is a phenomenon that PBL students elsewhere have also found uncomfortable (Woodward \& Ferrier, 1982). Perhaps al this early stage of their studies it might have been very difficult for the sludents to judge the adequacy of their learning. The students were not yet very sophisticated in 
comparing their interpretation of the content with the Faculty's objectives, as they were still learning how to learn with this educational approach. One instrument that will medsure adequacy of content will be the module test, and this is an area for review within the PBL programme. In the present study, all questionnares were completed soon after each PBL theme and before the students had experienced the related formative or summative assessment. Their concern and uncertainty was, therefore, quite reasonable. Some PBL schools, e.g. Maastricht University, include self-assessment tests as pan of the students guide document (Dolmans, 1994).

\section{Levet of Understanding of PBL Categories}

There was agreement by tutors on the students" level of understanding and the students" perception of the importance of community. social and ethical issues. However, seven ont of 3 tutors commented that critical appraisal would call for greater attention. 'Students just do not understand what critical appraisal means": "Faciliators and students all need to review whether we use the term critical appraisal to mean the same thing'.

The students did not comment specifically on critical appraisal. However. their responses from Theme One, Heath Care System, to the Theme on Prevention and Health Promotion demonstrated a steady progression from a high to a low mean value. During an informal review of this aspect with the male and a female student group, the students related critical apprasal to reviewing material from triggers in the light of mainly locally based research. As there was little local research available on most topics, they had difficulty in learning how to undertake critical appraisal. The concept appeared difficult to grasp, not only for the students but also for some tutors. It was not entirely clear how critical appraisal was dealt with by the tutors. Critical appraisal was reviewed during the PBL slaff development and turor training sessions, and tutors were encouraged to approach this as evidence-based medicine. Tutors were expected to help students in deciding whether information in the literature was valid and whether it was importat (Sacket of al., 1997). The concept of evidence-based medicine would appear to require more dedicated time for review discussion and better undersianding by the tutors. However, introducing First Year medical students to thinking deeper about issues, reflecting, critiquing and evaluating information should be of benefit to the students for handing heath and medical issues and debates in the future.

\section{Turoms" Perceptions}

Tutors were generally positive abou PBL. $90 \%$ lell that students worked whth enthusiasm. Just under $25 \%$ were uncertain whether the students had studied some aspects of the themes 10 an adequate depth. Future assessment results would indicate whether such concems were justified. 
The theme on Alternative and Islamic Medicine demonstrated low consensus for several questionnare items as indicated by high standard deviations. This theme dealt with debates related to the History of Islamic Medicine, Sharta Law and Alternative Medicinal Practices, which were woven into PBL triggers on "abortion" and "drug abuse". From a Faculty perspective these subjects did not lend themselves to open and easy discussion by students from a relatively conservative Moslem background. Some tutors felt that group interaction may have been inhibited by cultural/religious experiences and expectations. Interestingly, students demonstrated more positive scores in handling aspects of community, behaviour and ethics of this Theme than in the other four Themes. As most of the futors were expatriates, their assumptions and views may have been clouded by preconceived ideas on how these students might handle certain problem triggers. Gallagher (1993) alluded to the existence of a faculty-student gap in relation to cultural understanding. This will be th important issue to address, but it is beyond the scope of this report.

\section{English Language and Communication}

English as a communication barrier in group situations was highlighted by half the tutors and at least $30 \%$ of the students in their free responses. This ecthoed findings in an Australian sudy where students, whose first language was not English, reported that language was an impediment to eflective participation in PBL groups (O'Hanlon et al., 1995). In a local study Harrison et al. (1996) demonstrated the benefits of introducing UAE students to communication training early in their medical education. The importance of proficiency in English and how it affects classroom interaction, clinical communication and assessment outcome will require in-depth investigation in the context of local conditions.

\section{Gender and Culrural Issues}

The study indicated that male students were more positive towards PBL than female students who exhibited a degree of competitiveness that was not evident among the males. Working in groups is diffoult because each fewale student wants to be the best; in PBL you have to share, sometimes we do not want to do so. Some students found it difficult to work in groups. One female student indicated that they ough to have a choice 10 opt out of PBL sessions and have lectures only instead. Cox and Cooper (1977) identifed that behaviours demonstrated in group sessions are very much a reflection of the cultural noms of a society. The UAE is a traditional and conservative society. Within the UAE mascuine culture female competitiveness is "valued" and 'legitimate" outside the family (Hofstede. 1986). 


\section{Conclusion}

The study raised more questions than it answered. It emphasized the need for close attention to planning and introduction of PBL for the benefit of both tutors and students. On the one hand, the study demonstrated the ability of PBL to highlight educational concerns related to communication, language, gender and culture that might go unnoticed in a more traditional education system. On the other hand, the study echoed weaknesses of PBL, such as students' concerns whether PBL theme objectives were adequately covered (Woodward \& Ferrier. 1982). This study also identified how PBL can be complementary to other approaches to teaching and learning. Finally, programme review can be seen as paving the way for a holistic and in-depth evaluation of a PBL curriculum.

\section{Acknowledgement}

The authors would like to thank Gerard D. Majoor, Henk G. Schmidt, Hetty A. M. Snellen-Balendong, Jos H. C. Moust and Betsy Stalenhoef-Halling for permission to use the evaluation form, published in Z. M. Nooman, H. G. Schmidt \& E. S. Ezzat (Eds), Innovation in medical education: an evaluation of its present status. New York: Springer Publishing Co.

\section{References}

ABDLLRAZZAQ, Y.M. \& QAYED, K.I. (1991). A study of attitudes of the foundation staff of a new medical faculty to problem-based learning. Medical Teacher, 13, 281-288.

COX, C.I. \& COOPER, C.L. (1977). Developing organizational development skills in Japan and the United Kingdom: an experiential approach. Internasional Studies of Management and Organization, 6, 72-83.

DAS, M., MURDoCH, J.C. \& MPOFu, D.J.S. (1995). Problem-based learning in the Faculty of Medicine and Health Sciences. United Arab Emirates Universily. Al-Ain. Enwowes Medical dolumal, 13, 235-246.

DAs. M. Murdoch, J.C. Mpofu, D. \& Bener, A. (1996). The role of peer and sell-assessment during experientiall learning in community settings. Education for Heath, 9 .

DOLMANS, D. (1994). How studens learn in problem-based curriculum. "The Netherlands: Universitaire Pers Maastricht

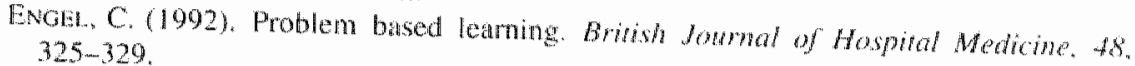

Galdahbr, E. (1993). Cumicular goals and student aspiration in a new Arab medical college. In: P. CONRAD \& E. GAL LAGHER (EdS). Heath and heath care in developing converies: sociologicaf perspectives. Philadelphia: Temple University Press.

HARRTSON, A.. GLASGOW, N. \& TOWNSEND, A. (1996). Communication skills training early in the medical curriculum: the UA experience. Medical Teacher, 18,3541 . 
HorstedE, G. (1986). Cuhwral differences in teaching and learning. Interhatonal homal of Interculural Relations, 10, $301-320$.

Manoor, G.D.. Schmid, H.G. Smellen-Ballendog, H. Movst, J.H.C. \& StalenhoffHALling, B. (1990). Construction of problems for PBL. In: A.M. Nooman. H.G.

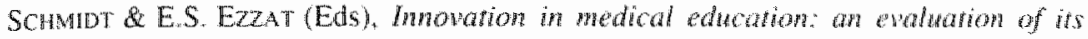
presen status. New York: Springer Publishers.

Norusis, M J. (1992). SPSS InC. SPSS/PC \& you Windows Base Sysrem and Adwanced Staristics User's Guide. Release Version 6.0. Chicago. SPSS.

O Hanlom, A. Winefield, H., Henka, E. \& Chur-Hansen, A. (1995). Initial responses of first year medical students to problem-based leaming in a behavioral science course: role of language background and course content. Medical Educanion, 29, 198-204.

SACRetr, D.L., RIChardson, W.S., Rosenburg, W. \& HavNes, B.R. (1997). Evidence based mediche: how to practice and teach EBM. New York: Churchill Livingstone.

SCHMIDT, H.G. (1993). Foundations of problem-based learning: some explanatory notes. Medical Education, 27, 422-432.

Woodward, C.A. \& Ferrier, B.M. (1982). Perspectives of graduates two or five years after graduation from a thee-year medical school. Joumal of Medical Edwcation. 57. $294-302$. 


\title{
Self and Tutor Evaluations in Problem-Based Learning Tutorials: Is there a Relationship?
}

\author{
Mandira Das, ${ }^{\prime}$ D. Mpofu, ${ }^{2}$ E. Dunn, ${ }^{2}$ \& J.H. Lanphear ${ }^{I}$ * \\ 1 Department of Medical Educarion and

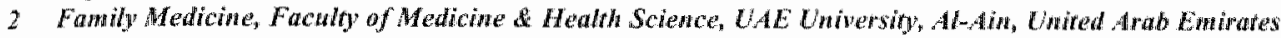

\section{SUMMARY}

It is now recognized that acquiring specific skills in selfevaluation helps students in a more general appraisal of their overall performance. Self- and peer-evaluation skills are essential prerequisites for the success of every doctor in maintaining professional competence. In the Faculty of Medicine and Health Sciences (FMHS) of the United Arab Emirates, problem based learning (PBL) is instructed in the first year. Self-evaluation by students and tutor rating of students' perfomances are an integral part of the PBL tutorials. This has provided the oppontunity to conduct a systematic study of the role of self-evaluation by students as distinct from the tutor evaluation of students in the PBL tutorials for five themes. The study sample included all preparatory year (first-year) students who joined the FMHS in 1994 and 1995. A total number of 64 students participated, of whom $17(26 \%)$ were male and $47(74 \%)$ female. Mean self-evaluation scores were high throughout the module and did not follow any trend from theme one to theme five. While self and tutor scores were similar, male student self-evaluation scores were higher than for female students in overall scores. The sharing of assessment reports between students and tutors has been perceived to be a useful tool for the siudents' development of the skills of analysis, differentiation and critical appraisal.

\section{Keywords}

Education, measurement; cducation, medical undergraduate, *methods; "problem-based learning; self concept; selfevaluation programs

\section{INTRODUCTION}

It is now recognized that acquiring skills in self-evaluation is a prerequisite for the continuing learning of every doctor. Helping students to develop these skills also helps in facilitating appraisal of their performance on an ongoing basis (Cowan 1988; Small et al. 1993; Stefani 1994). Only a few medical schools have made efforts to develop these skills while programming undergraduate and postgraduate curricula (Rezler 1989; Rawnsley er al. 1994; Das er al. 1996). In their review of self-evaluation studies, Boud \& Falchkov (1989) reported that high-achieving students tend to underestimate their performance while low-achieving students overestimate. Some studies report that selfratings by shdents could be different from those done by lutors (Stuart el al. 1980; 
Cochran \& Spears 1980, Sclabassi \& Woelfel 1984). Sudents find discussion about discrepancies of scores among self, peer and tutor useful as it helps to improve analytical habits, better understanding of the objectives of the curriculum and better communication with peers and tutors. Ir general, while reservations have been expressed about using self-evaluation for summative assessment, it has been accepted as a useful tool for formative assessment (Abrams \& Kelley 1974; Henbest \& Fehrsen 1985; Das et al. 1996)

Reported self-evaluation studies in the medical seting have primarily dealt with the ability to selfassess the performance of clinical skills. Reports on experiences related to self-evaluation in problem-based learning (PBL) curricula are scanty in the literature. This is in spite of the fact that evaluation of self, peer, tutor and the tutorial process forms an integral part of the PBL tutorial in many institurions and time is usually set apart for such evaluations. Rezler (1989) has reported that self-evaluation by students was not different from the tutor ratings during Unit 1 of the University of New Mexico "s problem-based primary care curriculum. However, students" selfratings were higher and did not correlate with those of tutors towards the end of the curriculum (Unit 6). Student self-ratings did not correlate with achievement in the National Board of Medical Examiners (NBME), but tutor ratings did. Rawnsley et al. (1994) have also reported the usefuness of self-evaluation as an integral component of PBL tutorial in Pinamacology and Physiology courses in McMaster University.

In the Faculty of Medicine and Health Sciences (FMHS) of the United Arab Emirates (UAE) PBL is instituted in the first year and self-evaluation by students and tutor rating of students' performances is an integral part of the PBL tutorials. This has provided the opportunity to conduct a systematic study of the role of selfevaluation by students as distinct from the tutor evaluation of students in the PBL tutorials. We have particularly addressed the questions of differences between self- and tutor evaluations of student performance during PBL tutorials and how students and tutors perceive the process of selfevaluation. Since the evaluations were done repeatedly as the students progressed from theme 1 to theme 5, we have also tried to find out if the self-evaluations change as the students progress over a period of time and whether these evaluations relate to achievement at the end of the year. Finally, we have tried to analyze ary gender differences that may bias the process of self-evaluation.

\section{METHODS}

The study sample included 64 first-year medical students who joined the PMHS in 1994 and 1995. The tolal number of students in 1994 were 27 and in 1995 37, of which $17(26 \%)$ were mitlo and $47(74 \%)$ were female. The preparatory course oflered to the first-year students follows an integrated curricular approach similar to subsequent years. Introduction to Medicine is one of the four modules that shudents complete during this year. The module has been designed to provide students with insight inio the health care system of the UAE and the socioculturat, psychological and enviromental factors that affect health and disease prevention and health promotion. The main goals of the module are to impart knowledge by analyzing medical problems; inculcate specific skills such as responsibility, the ability to process information, conmunicate, accomplish critical analysis and to increase student awareness of their own 
To implement the PBL programme, carefully constructed problems were presented to small groups of students. Each problem was associated with one theme and each problem had three miggers. One trigger was discussed in each PBL tutorial, which lasted for 2 hours. The students started tutorial sessions trying to clarify meaning of any words, terms or concepts. Next they raised issues from the problem which needed explanation, analysis and reasoning. A series of learning objectives were derived from the issues raised and these provided the ramework for seeking information. The information gained by individual students was discussed in a subsequent tutorial session. In the last PBL tutorial session, time was set apart for evaluation of self, peer, tutors and the tutorial process. A total of five themes were identified in the module.

For the PBL tutorial sessions each year the female students were divided into three groups. In 1994 the groups consisted of $6-7$ students while in 1995 there were $9-10$ students each. The male student (8 in 1994 and 9 in 1995) remained in one group. Each tutorial group undertook the same activities during the course of the module. Each group was assigned with one or two tutors. The tutors, most of whom were male, rotated among the groups for different themes. There was no gender bias in rotations. At the end of the last PBL tutorial in each theme, students evaluated themselves using an evaluation form and the tutor completed a similar form. Where there were two tutors, an average score was subnitted. The tutor marks were used as part of the intemal assessment whereas student self-evaluation marks were used for formative assessment. Students and tutors discussed congruence between self- and tutor evaluation at the end of the evaluation process. The module coordinator met the students at the end of each theme to further discuss issues that may thave arisen from self- or tutor evaluations.

\section{The self- and tutor evaluation form}

The form used for self- and tutor evaluation of students was adapted from Rangachari \& Crankshaw (1992), who developed the self-evaluation form to provide a format for students in a problem-based curriculum to use to acquire the skills needed for self-evaluation. Following a pilot study with 4 female and 3 male students of the second-year curriculum and after consultation with PBL tutors, minor modifications were made to the original form.

There are 15 items in the form representing five subscores: responsibility, information processing, communication, critical analysis and self-awareness. Ratings were distributed on a scale of $1-5$ from disagree to agree. An overall rating was asked for at the end of the form, which was scored as below average (1), average (2), or outstanding (3). Each form also had space for comments. The format of the self-evaluation form is reproduced in Fig. 1 . The tutor evaluation form was similar to the self-evaluation fornt, with appropriate changes as necessary. Students and tutors were encouraged to give their views along with reasoning on the usefulness or ofherwise of selfevaluation in PBL systems, for which space was provided as "comments" on the forms. These items were also collated to gauge the respective perceptions of the students and tutors. The organtzers of the module met the students and the tutors for feedback about the selfevaluation process at the end of all the themes. 
Name of the Studertit:

PBL. Sestsion:
Nane of the molor:

Diate:

Indicate the strength of your agrement/disagrement on the five point scale given with each statement, I representing disagrement and 5 agrement.

\section{A. Responathility}

1. I completed all assigned tasks to the level appropriate for the worial

2. Jarticipated actively in the tutorial

3. My behavior did not impede the tutorial process

4. My behawor facilitated learning of others

5. I was punctual in ach PEL session

\section{B. Information processing}

1. I brough in new information

2. The infomation I brought in was relevant to the discussion

3. I used sariety of sources to obmin information (texts, review Arteles, video, valking to patients and peers, etc.)

\section{Commonication:}

1. I was ablo to communicate the ideas clearly

2. My comments did not confuse other students

D. Critical analysis

1. I justified the comments made

2. My comments promoted understanding of the subject by the group

3. J am interested in the problembased teaming approach $\mathrm{C}$

\section{E. Self-awareness}

1 I assessed my own strengths and weaknesses

2 I am able wo acept and respond lo criticism grace fully

Based on the above my tutorial performume wat

\section{Bolow Average}

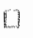

Aprerage

\section{1}

2

3.

4.

5

$\begin{array}{lllll}0 & 0 & 0 & 0 & 0 \\ 0 & 0 & 0 & \square & \square \\ \square & 0 & 0 & 0 & \square \\ 0 & \square & 0 & \square & \square \\ 0 & 0 & 0 & 0 & 0\end{array}$

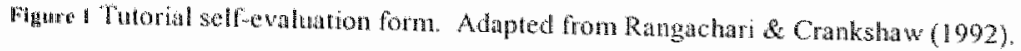

At the end of the year students were assessed in a written examination where two modified essay questions (MEQs) of 2 hours each were used as an instrument for assessing knowledge, reasoning and critical analysis skills. High-and low-achievers were identified from this test to find out whether self-evaluation and tutor evaluations relate to achievement at the end of the 


\section{Stentistical methods}

The selfevaluation form included five categories with $2-5$ items under each category. The categories were responsibility, information processing, communication, critical analysis and selfawareness. A subscore for each of the five categones was created for both self- and tutor evaluation by averaging across items for each of them. Mean ratings were calculated for each of the five sub-scores. Comparisons between self-and tutor evaluations were made using Chisquare and paired t-test. Correllation coefficients were obtained to study congruence between self- and tutor evaluations. Sex differences were tested using Student's 1 -test.

\section{RESULTS}

A total of $316(98.7 \%)$ self-evaluation forms were completed by the students and the same number of tutor evaluation forms were collected in the 2 years of sampling.

\section{Are there differences between self- and tutor evaluation of students performances in PBL. tutorials?}

The comparisons of self- and tutor evaluations during the 2 years are shown in Table 1, which gives the respective mean rating, standard deviation and $P$ value for each subscore. Statistically significant differences were present only fon the categories of responsibility in 1994 and selfawareness in 1995.

Table 2 displays the correlation coefficient for self- and tutor subscore ratings and for the overall score. In only two instances were the correlation coefficients significant. The self- and tutor overall scores had a small but negative correlation coefficient (not significant).

The cumulative date over 2 years showed that the students" overall ratings of their performance were significantly correlated to all of the subscores $(P<0.001)$. The tutors' overall ratings of students was not correlated with the students' overall ratings $(P=0.609)$ or with any of the subscores except responsibility $(P<0.001)$.

\section{How did the students and the tutors, respectivelly, perceive self-evaluation in the PBL. tutorials?}

Eighty percent of students and $70 \%$ of tutors expressed the wiew that the exercise of scoring self and comparing self-evaluation with tutor evaluation was beneficial to them. Some reasons given by the students were "it has clarified the objectives of PBL tutorials". "I know what teachers want me to do during the PBL tutorials", "I know how tutors mark", "We know how pecrs are assessed by tutors" and "I became aware of ny role". The tutors fell that it provided an opportunity to "help the students who are not confudent or who are over confident". "discuss objectives of PBL tutorials" and "inform about the expectations of the tutors and the organizers in a PBL curriculum". Both the students and tutors reported that discussion about student performances and tutor evaluations at the end of PBL tutorials help to create closer relationships. betweer students and tutors. However, both students and tutors found that this method of self- 
cvaluation took too much time during the tutorials and was too frequent during the year. Both students and tutors expressed views that the form was too long to complete at the end of each theme and that it should be done only once in each semester. Students, however, were strongly opposed to the use of self-evaluation in summative assessment and said that the teachers know better about assessment and that it should be the teachers who assess them. Seventywive percent of the students believed that self-evaluation should be used for formative assessment but not in summative assessment. Eighty-three percent of the tutors had similar opinions. Students felt that sone tutors were more strict than others and this was why some groups obtained lower marks than others.

Table 1. A comparison of stell and sutor evaluation fesponses.

\begin{tabular}{|c|c|c|c|c|c|c|}
\hline Subscores: & $\begin{array}{l}\text { Self }(994) \\
\text { Mean }\end{array}$ & $\begin{array}{l}\text { Tutor }(190,4) \\
\text { Weary } \pm 50\end{array}$ & $\begin{array}{l}\operatorname{Self}(1995) \\
p^{n i}\end{array}$ & $\begin{array}{l}\text { Twtor }(1995) \\
\text { Mean }=5 \mathrm{D}\end{array}$ & Mean \pm SD & $y^{2}$ \\
\hline Responibibitity & $4.34+6.51$ & $4.46 \pm 0.53$ & 0.015 & $4.56 \pm 0.44$ & $4.55 \pm 0.50$ & 0.869 \\
\hline Information processing & $4.28+1.60$ & $4.23=0.56$ & 0.724 & $4.39+0.57$ & $4.33 \pm 0.54$ & 0282 \\
\hline Communication & $4.37 \pm 0.59$ & $4.48 \pm 0.52$ & 0.070 & $4.56 \pm 0.60$ & $4.54 \pm 0.49$ & 0.846 \\
\hline Critican analysis & $4.23 \pm 0.55$ & $4.32 \pm 0.50$ & 0.997 & $4.53+0.64$ & $4.42 \pm 0.55$ & $0.13:$ \\
\hline Self-enwaremess & $4.35+0.52$ & 4.219 .0 .53 & 0336 & $4.56 \pm 0.62$ & $4.40+0.64$ & 0.520 \\
\hline Owerall (Sigate 1-3) & $2.39+0.52$ & $2.49 \pm 0.50$ & 0.052 & $2.50+0.55$ & $254 \pm 0.50$ & 0.520 \\
\hline
\end{tabular}

Paired intest was used. SD, standard dowation.

Table 2. Correlation between self and tutor scores over five themes in both the years.

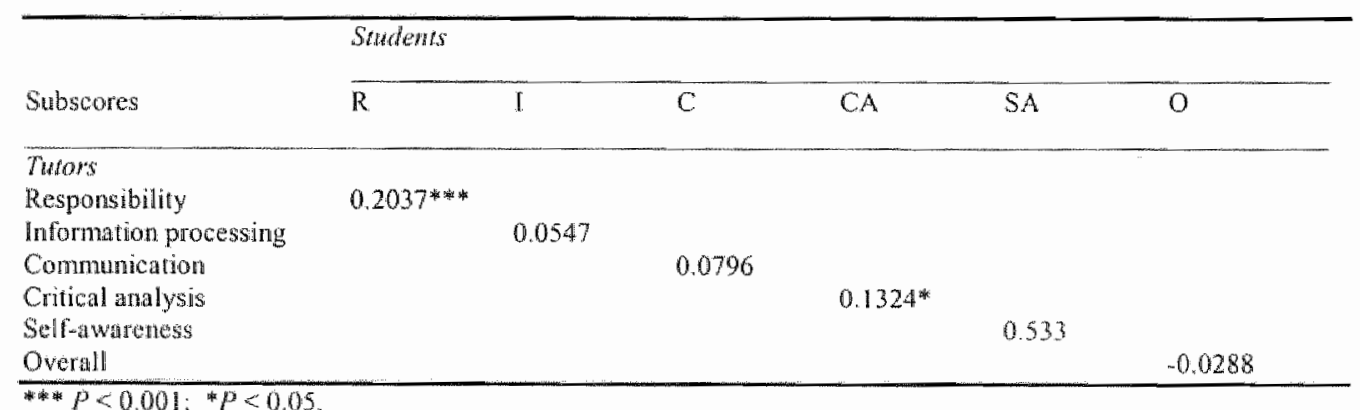




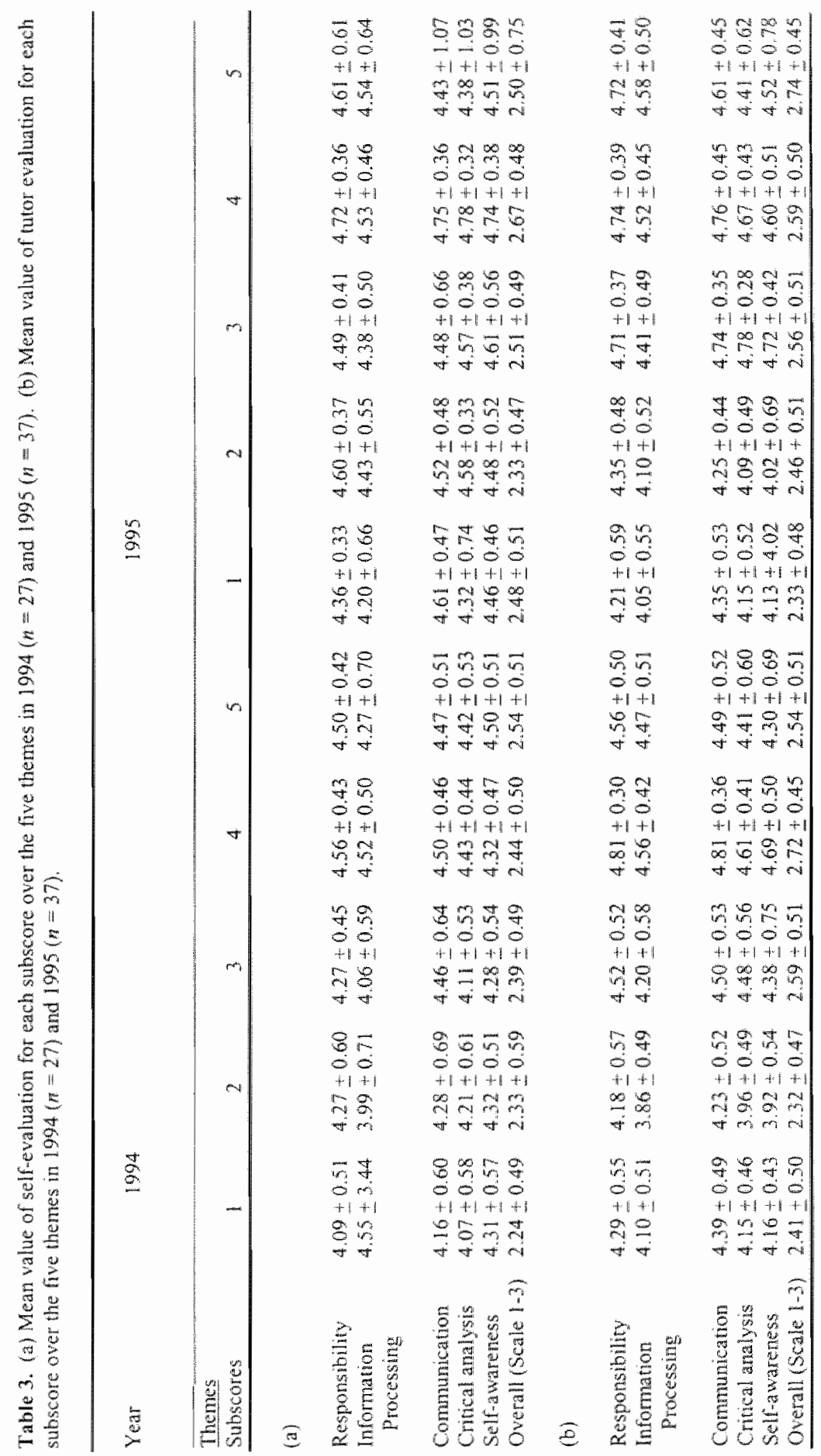




\section{Do self-and tutor evaluations change with progress of students in PBL tutorials?}

Mean selfevaluation scores were high throughou the module (Table 3 ), ranging from 3.99 for information processing in theme 2 (1994) 10 4.78 for critical analys in theme 4 (1995). The minimum individual score was 1 and the maximum individual score was 5 . The subscores did not show any significant difference over time for any themes except for responsibility, where students consistently gave higher self-ewaluation scores as they progress to theme $5(P<0.001)$ during 1994. Mean tutor rating scores were also high throughout the module, ranging from 3.86 for information processing in theme 2 (1994) to 4.81 in theme 4 (1994). The subscores did not show any significant trend as student progressed from theme 1 to theme 5 .

\section{Do self- and tutor evaluations relate to achievement at the end of the year?}

The student scores in the end of the year written examination ranged from $70 \%$ to $93.3 \%$. The students were categorized into high- $(>90 \%)$, middle $-(>80 \%$ and $<90 \%)$ and low $-(<80 \%)$ achievers. These categories were not correlated to any of the subscores except that highachievers were less likely lo give themselves a high rating than low-achievers. Students of all three categories scored themselves as either average or outstanding. The tutors also scored approximately half of the students of each category as average or outstanding. None was ranked as below average. There was no significant correlation bewcen student achievement scores and self- or tutor evaluation scores for all subscores and for overall scores.

\section{Is there any difference in self-evaluation between male and female students?}

Table 4 gives the respective mean selfevaluation scores for each subscore. There were no significant differences between male and female in these subscores. This is in contrast with the fact that the female students gave themselves an "overall" score, which was much lower than male students gave themselves. This difference was highly significant $(P<0.0001)$.

\section{DISCUSSION}

This study investigated the evaluation of medical students by self and tutors about their participation and attitude in PBL tutorials. PBL emplasizes self-leaming, where students are expected to take responsibility, be good communicators, be able to process and critically analyze information. Students are expected to be aware of their own strengths and weaknesses as a way to improve their performance. In this study, self-evaluation scores during learning in the PBL tutorials corresponded reasonably well to the futor evaluation, with mean values for both evaluations in the thigh range. This congruence was present whth respect to all the subscores. This holor probably reflects a positive attitude of the students and utors towands a curriculum that was new to them and allowed the students to evaluate their own perfomances. This conguence also provides positive feedback to the module organizers that the understanding of the students and the tutors about the goals of the PBL tutortals and responsibility of the students in a self-leaming curricuhm were clear. This is mportant because differences in student and 
Table 4. A comparison of self-evaluation between male and female students.

\begin{tabular}{llll}
\hline & $\begin{array}{l}\text { Male }(n=17) \\
\text { Mean } \pm \mathrm{SD}\end{array}$ & $\begin{array}{l}\text { Female }(n=47) \\
\text { Mean } \pm \mathrm{SD}\end{array}$ & $P_{\text {-value }}$ \\
\hline Subscores & $4.44 \pm 0.46$ & $4.43 \pm 0.50$ & 0.847 \\
Responsibility & $4.45 \pm 1.42$ & $4.28 \pm 1.26$ & 0.009 \\
Information & & & \\
processing & $4.43 \pm 0.68$ & $4.46 \pm 0.61$ & 0.729 \\
Communication & $4.25 \pm 0.73$ & $4.39 \pm 0.55$ & 0.054 \\
Critical analysis & $4.37 \pm 0.71$ & $4.46 \pm 0.51$ & 0.240 \\
Self-awareness & $2.73 \pm 0.51$ & $2.32 \pm 0.50$ & 0.000 \\
Overall (Scale 1-3) & & & \\
\hline
\end{tabular}

"Student's i-test was used. SD, standard deviation

tutor ratings could occur in a PBL tutorial performance evaluation if the aims and objectives of PBL tutorials are interpreted differently by then and if their roles and responsibilities ate not clear. Discrepancies between student and tutor scores found by Stefani (1994) was thought to be due to lack of experience of students in self-evaluation and to possible differences in interpretation of criteria for scoring.

Rezler (1989) observed that the self-evaluation scores tended to be high as the students progressed over a period of time. Woolliscroft et al. (1993) also showed a significant increase in the initial self-assessment as the year progressed and students gained more experience. The continuing self-evaluation of all subscores as the students progressed from theme 1 to theme 5 in the present study revealed no such pattern and the fluctuations of self-evaluation scores from theme 1 to theme 5 showed no statistical significance. The students showed self-confidence throughout the module and scored themselves in the high range from the beginning. High scoring by the students at the beginning of the course probably shows self-confidence of shdents as they join a prestigious institution after tough competition (Rezler 1989). High scoring by self and tutor in both years could also be the reflection of the high pass mark (75\%) expected from the students of the FMHS.

In Rezler's (1989) study, tutor ratings and not student ratings correlated with NBME scores. He concluded that the students may have rated themselves according to the goals of the tutorials, while faculty rated them on different criteria. Boud \& Falchikow (1989) reported that the highachieving students tend to underestimate their performance and low-achieving students overestimate. Woolliseron ex al. (1993) also made similar observations in their sludies on the predictive value of self-evaluation in clinical performance of students. Our results showed that high-achievers did not identify themselves and self-evaluations of high-and low-achievers were similar. Although the MEQs were structured to assess reasoning and critical analytic abilitics, they probably required skills other than those required to perform well in problem-based tutorial 
sessions. To acheve a high scone in writch waminations, students need to have a good command of language. English is a second language for many Preparatory Course students and they may have relatively poor comprehension and writing abilities. A good participant in a $\mathrm{PBL}$ tutoriat may not necessarily be able to comptehend and express himherself in a written form. This send an important message to the organizers of PBL to consider modifications of the assessment format of the PBL curriculum.

Subjective perceptions of both students and tutors had a reasonable amount of concordance on self-evahation skilss and their role in learning. In spite of this, the majority of students wanted its role to be limited to only formative assessment. They were against its inclusion as a summative assessment. The FMHS students bave shown in other studies that they place considerable trust in faculty decisions about curriculum design and assessment (Das et al. 1995; Das el at. 1996).

An observation that is unique to this study is the perceived gender difference in self-evaluation. "The evaluation of subscores in our study is highly objective due to the structured format and clearly stated items; however, the overall score at the end of the self-evaluation form may be a subjective expression of self. The female students had similar self-evaluation scores as the male students in all the subscores. In spite of this, the overall self-evaluation by the female students was quite low and this difference was statistically highly significant $(P<0.0001)$. The fenale students were also more critical about self and peers during the feedback sessions following selfand tutor evaluation. Selfevaluation is a reflection of how a society views its members. The reason for this gender difference finding could be related to culture and the beliefs in a society. Arab countries, like those studied by Hofstede (1986) have been identified as collectivist socicties, where women aceept inequality. On the other hand, such gender differences may be more universal. Roberts (1991) has reviewed the pertinent literature and argues that men and women do indeed have different approaches to evaluative achievenent situations. Males are more likely to adopt a self-confident approach that leads them to deny the informational value of other's evaluations. Females may be particularly likely to approach such situations as opportunities to gain information about their abilities.

\section{CONCLUSION}

Sudies such as this one that seck to ascertam the impact of new methodologies on students whose traditionat educational models ane authoritarian teacher-centred and rely on external motwation raise more questions than they answer. Wevertheless, they are clinically important to medical schools attempting to inculcate a sense of lifelong leaming, introspection as well as selfand peer appraisal, which is so important to the long-term profession of doctors. Clearly, the students in this study were able to assess their abilities in concordance with tutors, although there were significan gender differences. Further study over time will perhaps tell us whether or not remale perceptions change as the society becomes more egalitarian and as the large member of current female students enter practices. 


\section{ACKNOWLEDGEMENTS}

The auhors are thankfil to Professor P.K. Rangachari, McMaster University, Canada for permission to use the questionnaire. The authors would also like to thank the tutors and the sudents who participated in this study.

\section{REFERENCES}

Abrams R G \& Kelley ML (1974). Student self-evaluation in a pediatric operative technique course. Jounal of Denral Educarion 38, 385-391.

Boud D \& Falchikov N (1989). Quantitative studies of student self-assessment in higher: a oritical higher education. a critical analysis of finding. Higher Education $18,529-549$.

Cochan S B \& Spears MC (1980). Student self-assessment and instructors ratings: a comparison. Journal American Diet Association 76, 253.255.

Cowan J (1988). Strugghing with student assessment. In: Developing Suden Antonomy in Leaming (ed. D J Boud) pp. 192-210. Kogan Page, London.

Das M, Lanphear IH. Liewald D \& Oyejide C (1995). Perception of faculty about students attitude towards "Teaching/leaming modal ities. In. Procedings of the Sixh Onawa Confrence on Medical Educatron (eds A R Rothman R Cohen), pp. 647-651. Custom Publishing, Toronto.

Das M, Mpofu D, Murdoch C \& Bener A B (1996). Role of peer appratsal and self-assessment duing leaming in community settings. Education for Heallh: Change in Training and Practice 9 (2), 239.249.

Henbest R J \& Fehrsen G S (1985). Preliminary study at the Medical University of Southern Africa on student self-assessment as a means of evaluation. Jownal of Medical Edhcation 60, 66-68.

Hofstede $\mathrm{G}$ (1986). Cultural differences in teaching and leaming. Inemational Journal of Intercultural Retations 10, $301-320$.

Rangachari P K \& Crankshaw D J (1992). Formative evaluation in a tutorial-based course. In: Procedings of $5^{\text {th }}$ Instructional Show and Teth for Ontario Universities, p. 125-130. University of Guelph, Guelph, ON

Rawnsley K., Spaziani R \& Rangachari P K (1994). Evaluation in a problem-based course: contrasting views of students and teachers. PROBE12,9-14.

Rezler A O (1989). Self assessment in problem-based groups. Medical Teacher 11 (2). 151-156.

Roberts $\mathrm{T}$ (1991). Gender and the influence of evaluations on selfassessments in achievement sethrygs. Psychological Bulletin 109,297-308.

Selabass SE \& Woelfel S K (1984). Development of self-assessment skills in medical students. Medical Edication 18, 226-231.

Small P A Jr. Stevens B \& Duerson M C (1993). Issues in medical education: basic problems and potential solutions. Academic Medicine $68,589-598$.

Stefani L A J (1994). Peer, self and tuior assessment: relative reliabilities. Studies in Higher Eiduchion 19.69-75.

Stuart M R, Goldstein H S \& Snope F C (1980). Sellevaluation by residents in Family Medicine. Jound Fandly Procice 10, 639-642.

Woolliscroft J O, Tentlaken J \& Calhoun J O (1993). Medical sudents' clinical selfassessments: comparisons with external measures of performance and the students" self-assessments of overall performance and effort. Academic Press 68,285-294. 


\title{
Perceptions of group dynamics in problem-based learning sessions: a time to reflect on group issues
}

\author{
D. J. S. MPOFU', M. DAS ${ }^{2}$, T. STEWART ${ }^{3}$, E. DUNN' \& H. SCHMIDT

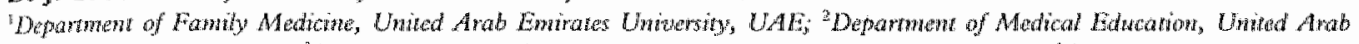

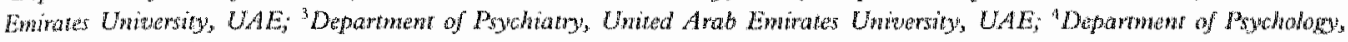 \\ Uniwersidy of Limbarg, Madatrich
}

\begin{abstract}
sumwalis Problem-based" learring (PBL) educational settings are thesign studios for reflection on group dynamios perceplions. Mon PBL studies report aspacts related to cogntwite shills

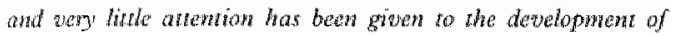
group-related stills. This study reports on students" and faculty perceprons of group dynandics. A guestiontatipe was wed to collec data frow students following completion of each of four PRL themes. Data frow fturars was collected ustrig a more opin-ended fonmat. Feedback and discassions post-PBL themes offered weflective opportwivides for groups. Differences watre noted in what students and wors perceind as important, demowstrating a fachly student gap. The female students stated impornan arpecs wo be areas which facilitated their leaming and axam

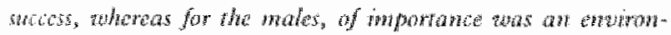
ment anducive to participation by alt fyrther, gender differ-

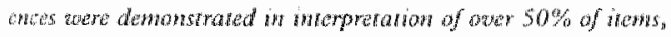

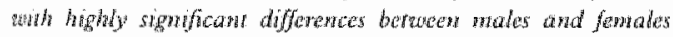
$(p<0,001)$, in just whder $25 \%$ of irems.
\end{abstract}

\section{Introduction}

Very litte research has been undertatern on faciliating group dynamics sklls during the education ard training periot of medical students. In problem-based leaming (PDH, whorials the group process relles heavily on several farerars one of which is indicated as gronp dymamies (Kauf man 1985; Schmid 1993; "Thping et al., 1995). Earlict the imponance of group dynanics skifs in experiential learning sinuations was highlighted by Bollag of at, (1982). Resareh has identified the tremendous growh in medical and other heallh-related schools adapting $\mathrm{PBL}$, as a mode of teaching and lcarring (Albanewe \& Mitchell, 1993). What is lacking is studis on actual practicalites related to dewtoping and dealing with appropriate PBL group behat lors (Tinping at al, 1995). The importance of facilital ing practitioners to think about what they are doing while they are doing it has been deflned as rellective practice (Shon 1991). Schon (1991) ps. Curther identifies the relctance dilemma indicating that "what aspiring profes sionals need most to learn, professional schools seern least able to tesch" It is essential, therefore, that future physichans develop, review and refine gromp dynamic stills as part of their undergradunte medical chriculum.

At the Fuculty of Medicine and Healla Sciences (FMHS), United Arab Emirates (UAF) University all the medical students are UAE mationals and mote than $90 \%$ of Vaculty statt are expatriates. Sexunl segregation of students is practiced throughout the seven years of traning. PBL used in the preparatory year, the first year of medical education and training, is identified as one of the key aducational principles of the FMHS. Curriculum planners developed certain objectives in relation to PBL tutorial. groups. "These are:

- development and retinemone of communtention and in. terpersonalal sikitsi;

- stimulanion and creouragemen of self-directed letring:

- facilitaion of information marbaguthent skills which cover climical reasoning and problem managemen;

- Costering suden growh in responsibility in relation to self, pecs, educationd establishment and future profession;

- devclopencrit of effective professional behawor

- identification, utiluation and refonement of set and pecrevaluation arategies;

- capability to uffer one another support cmotionally and socialy in onder to foster personal growth.

"lithese obicetives are in keeping with the goals of huorial groups as identified by Lucero a al, $(1985)$. furom a lacal perspective, nodule pliamers also wan to develop latader ship skills and reflecture praxis in our medical studeribs. Anecdoral evidence suggests that sudent-centered learning in whe form of PlBL. is an wherely new phenomenon to the radority if not to all the leMHS rew medical studchis. What, therefore, are the important isuce to constate in chcouraging medical students and their tutors to not only think of but expericnce and revicw aspects that contribute to harmanious group furyctioning? 


\section{The gatidy}

This sudy reports the perceprions of group dyames fothered followng four out of twe PML theries encountered "yy suderu in one wedemic year. The iswes addressed were wofold. First, what were the most imponant and ledst importan subelcments of group dynamies perceived by whors and studens in ML Groups, Second, what were the diftering perceptions of group dynamics by: (a) the sudents from one $1 \mathrm{PBL}$ theme to another, (b) between male and fenale sudems regarding perceptions of group dynamics whinin PBL, groups.

\section{Methodology}

In the preparatory yewr, the first year of medical education and raining, 140 hours are dedicated to the Introduction 10 Medicine Module (IOMM). This module accounts for five hours wetkly. Two hours per week are used for PBL and the rest of the time used for practical siknls sessions, ficldwork activites, one to tho lecrutes per theme and sell-study,

In September 1096, 49 students entered the preparatory year. During the course of the year thre students left the program, resulting in 16 males and 30 fenales, making up two male and four fomate PBI groups. For cultural and religious rexsons males and females are taught in separate groups. Studcnts were assigned randomly to groups and not allowed to change groups for the daration of the ITMM. Students received a twoweck PBL, orictitation program, where in small groups they were introduced to the principles of group licaming, and reviewed the roles of group members. group rules and effectöe group functioning. Students were introduced to practice PBL triggers, and worked through the steps encountered during problem-based learning situarions. The introduction to the library was related to their information search following exposure to the practice trig. ger. Consultation with experts and/or redevant organizations and the use of the skills laboratory facility were cheouraged. lkeport back and ewtlantion, followed by discussion of assessment methods coneluded the traning. The role of staden group lesder and that of saribe rotated mong the group menters. During the course of the year esch student had in opporturizy to practice the role of student leader and that of scribe. In tackjing the problem riggers, groups were Hatroduced to a modified form of the components of the PBL procesa, as described by Sclmide (1993) and later by Dolmans (1094). The PBL process adopted at UAE University is atcocribed fully in Das at at, (1995).

The PBL themes covered wete Health Care System (HCS), Alernatine and Islanic Mediche (AIM), family Wowh (FAM), and Infectious Diseases (INMD). On completion of esch thene the students individnally com pleted a group dynamics survey form. Tutors completed a similat open ended guestionnile, however, where there ware two tulors they discussed their perception of group dynamics and submitted ant form. Tutors" comment shoets distinguished between very imporant group dymamhes issucs ind those of lesser importance. A notal of 184 (100\%) group perceprion forms by students and $22(91.6 \%)$ tutor perception forms were completed following the PBL thenes.

\section{The group dynawics stritey form}

The sumey form used was adapted from Tipping er at, (1995). To prowde concepts and a description of effectw

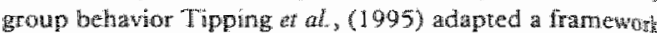
Trom behwiorat sciences (Dimock 1993). Using the wh efements wilized by Tipping at at, (1995), a plot study was undertaken on six male and six female students at the end of the 1995 96 acadenic year. Necestram modifications were made to the form. There were 41 icms on the form representing eigint categrates of group dynamics. These caregories, given in Table 1, were: physical chnate, emotional chmate, involvement, ineraction, cohesion, prom ductiwy, the student as group leader and the tulore facilitators. Ratings were distributed on a scalle from mot important (0) to very importane (10). Each form had a space for comments. The utors group dynamic form listed the same categries as abowe; howews, rutors were nequired to only make open-ended comments under each catepory in retation to the various items per category. There was an opportunity at the tend of each theme for students, PBI. tutors and modulio planners to review and reflect on growp dyramics issues pertinent to the theme just completed.

\section{Siatisticad analyis}

The data were entered into ACCESS and then imported inta the Statistical Packages for Social Sciences (SPSS) ror analysis (Frankfort-Nachmias \& Nachmias, 1996). Subscores for each of the eigh group parception categories were created for individual students, by averaging across indiwid. ual iterns. Mean ratings were calculated for each of the eigh catcgorics. Comparinons between groups and by themos were made. The $t$-test was used in andyzing differencas between male and female students.

\section{Result:}

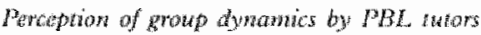

of those turor who paricipated in the study. $77.2 \%$ of them corrmontiod on physical climatc and inwolwement issues as very important. On the other hand students identifed aspecs retating to physical clinuate, such as

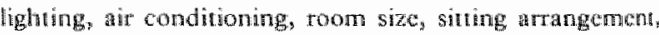
distractions, as of least importance in group dynarrics Turots identifed large rooms, unsuitable room fighting, ain conditioning that made the rooms sometimes roo cold, its very important. Thors identified that situng arrangement in lecture rooms, where seass needed rearranging into semi-circles prior ho each PBL session, was more a muisance and regarded this as of lesser importance. further issues such as students arriving late to sessions, or disturbances from students in other years, was, although reganded as of lesser importance, highly irriating to $45.5 \%$ of faculty stat

The tutors highlighted sorne discomfort and insecurity with the role of PBL nutor, in five out of the 22 nuror perception forms completed. The oher group dynamics categories received minimal comments by the tutors.

Percepion of growe dymomics by students

The mosi mportant areas in relation to group dymamics for 
Table 1. Results of t-test for independent samples of gender differences in perceptions of group dynamics ower four PBL themes (total mile responses $=64$, total fervale responses $=120$ ).

(1) Physical clinate

Lighting

0.061

Use of thip charts

Siting atrangement

0.553

Air conditioning

0.59

Distractions

(2) Emotional climate

Cooperativeness in the group

0.0.1.7\%

Support for sudert leader

Having formal tutor support.

$0.000^{* 1 \%}$

Accepting and not judging others

$0.032^{\text {in }}$

Pride in the group

0.341

(3) Inotwenthent

Knowing PBL objectives

0.320

Knowing the goals of PBI

0.234

Interest in the group

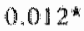

Curiosity about problems to be dincussed

$0.000 * *$

Atrentiveness

0.266

Commitment to the group

$0.000^{\text {two }}$

Lateness and absenceeism

$0.003^{* * *}$

(4) Interaction

Listening to tach and every one

0.137

Communication with all

0.077

Participation by all

$0.01^{1 *}$

Balance of tasks

$0.042^{*}$

Subgroups having power

0.210

Individuals having power

$0.010^{*}$

(5) Colnesion

Degree of how well group works together

$0.006^{* *}$

Accopting majotity decisions

0.129

Adhering 10 group rules

$0.000^{* * *}$

(6) Poducturisy

Linderstanding the goals for the theme

0.198

Having clear goals for the theme

0.135

Illaving foll follow the plan

$0.000^{\text {di }}$ th

Making plans: for the next session

$0.0090^{\text {th }}$ :

Hawng a foxible plan for raching the gow

$0.050^{k}$

Having an contribute

$0.016^{\text {*⿻ }}$

Having decistons rom last session carricd out

$0.000^{* * *}$

Making plans for the next session

0.055

Eutalusing group effectiveness regularly

0.054

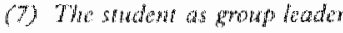

The ettect of the studen leader on the group

The stye used by the studen leader afecting group funchioning

The effec of student leadership on group participation

$0.000 \times$ we

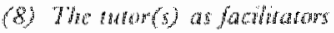

The tuthes style as facilitatot (s) affecting group functioning

$0.001+x$

The effect of the futor(s) faciftation on the group

$0.001^{12 \times}$

"The effect of tuter(s) facincation on group participation

$0.000^{\text {से }}$

(9) Commonts

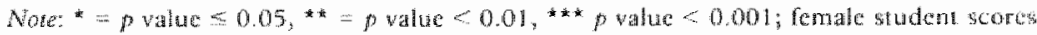
were highter than the scores of the trate students. 


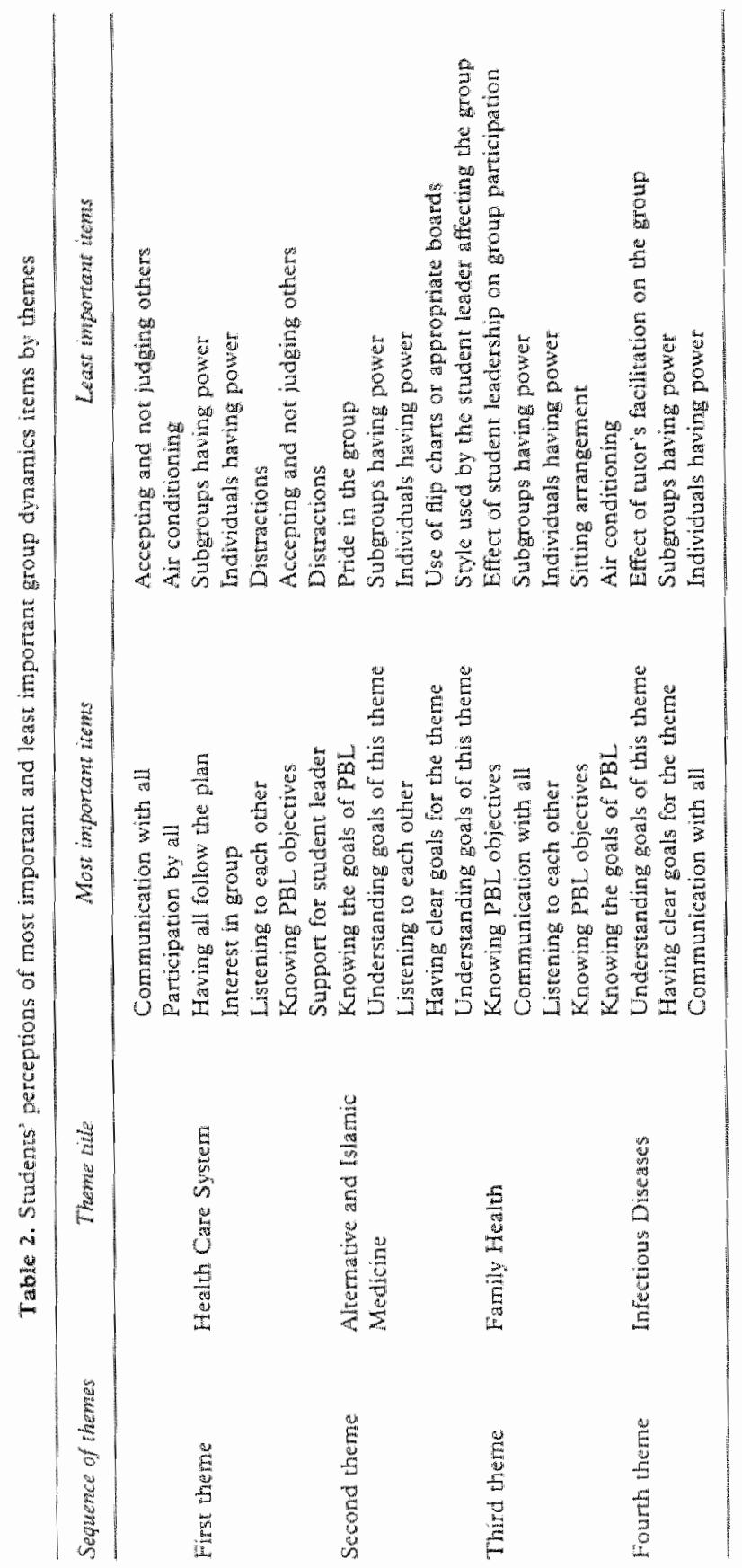


We ix PBL groups were identified as those areas given mean score of wine or more, and fell ino the following caregories: involvement, interaction, productivitys, and nutor(s) as facilitators. The particular items were: knowing PBL objectives, knowing the goals of PBL, understanding the goals of $\mathrm{PBL}$, hawing clear goals per theme, incerese ir the group, listening to each and every one, communication with all, having all follow the plan, making plans for the next session and the style used by the tutor(s) as facilitators affecting group functioning. The range of the mean scores for these items was 9.00-9.63 (standard deviation 1.25 1.82).

The areas that were identified as of less importance were areas with a meat score of less than the value cight. "These areas were: physical chwate-situng arrangement, air conditioning, distractions; emorional domata prite in the group; interccion-subgroups having power, individuals having power.

The students" views on group dymamics were examined by themes: with the first theme, HCS, areas identified as most important were aspects relatod to communication, listening, participation, interest in the group and laving all follow the plan. Communication and listening aspects remained wery important issues for the groups for the succeding themes. However, with subsequent thomes there was identification of a need for knowing and being clear about PBI objectives and stlso understandirig the goals of each PBL. theme. Requiring support for the stu. dent leader was identified as highly important in the second theme, AIM. However, by the third thene the style and effec of student leadership on group participation was regarded as less important (Table 2 ).

Of least importance to the sfudents in all four thanes was whether subgroups or individuals had power within the groups. Furthermore, inems relating to physical chwomment, accopting and not judging others were identifed as of minimal importance. By the fourth thene students chen perceired the tutors" facibution as of lible impromance (Table 2 ).

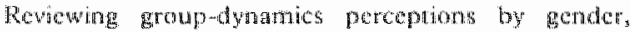
there were significant to highly significant diferences between mate and fenate students perceptions of over $50 \%$ of itoms. The fomalos demonstratod a general ten dancy to waluate most aspects of group dymamics as more mportane than did the males. In Table ${ }^{2}$, the atress where very highly significant differences were identifed were pro marily the categoriog rehating to the student acting as group leader and faciltation by the tutor(s). Further tems were also idcotifed the highly significan and hese were: having Conval tutor support, curtosity about problems to be diswosed, adhering 10 group rules, having all mermbers follow the plan, making plans for the nex session and having decisions from the last session carried out (see Table li)

\section{Discussion}

The study" sought to idernify students" a a tutom" perceptims ahout group dmamics, and forther wo highlight what Sscues they considered as most and least important. "The resulis highlighted some distinct issues about group dynamics in a PBI. program.

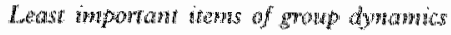

In all four IBL themes, of leste importarce were aspers, 10 do with individuals hawng power or subgroups having power Table 2). Surprisingly without consulting on another, the mijority of students in completing the group dyamics questionnatre indicuted that having a powertel individual whin g group was not impontant. Hequality exises in all cultures; howewer, the degree of it that is tolerated varies from one culture to another. Hofstede (1986) identifies the UAE as a country whin large power distance. This means that it is a culture where the less powerful persons accept incquality in power and consider ir as nomal. What was illuminating here was the tutors and observers' comments on noy-verbal group communicat on, as a very strong weapon amongst mombers. Whate a student did not do his/her homework between PlBl. sessions, or where a studert was repeatedly late for sessions, or where student or group of one or two students dominated the group, group members did not and would mot openly confront their collagace(s). This occurred even when tutors raised these issucs during gront etwhation and reflection discussions. Studertis preferted to ignore the deviant member(s) and proced with other group issues, thus mantaning group hamony. Some expariate tutors found this reductunce to actually confron what they per-w coiked as important group functional issues diflouh to accpt. This demonstrates a possible atimde difference that might be culturally telated, choing a "Fculty stadent gap' as inchufied by Gallaghe (1993).

In many siruations such as group dynamics, faculy have their own preconceived ideas aboun whthe is really jomportant, and the students may have st tomally different view as indicance in the resultis it is therelote, important to clarify from the outset how lo deal with, for exampla, lateness to and absentecism from lPBI. sessions and; fur ther, to clarify whether there is an obligation on the students side to be prescent at all PBL sessions and explain why this is so. lin a traditional schon students opl out al fecture scsions whithe penally, socept the necessty to

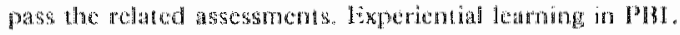

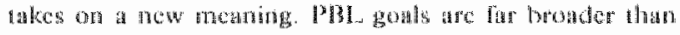

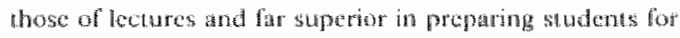

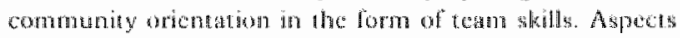

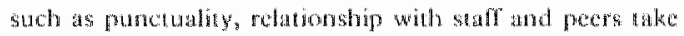

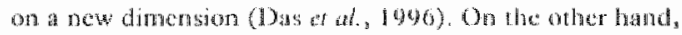
baring rooms dedicated to small-group acathing where averyone is made aware of the need ro redise disturbanow

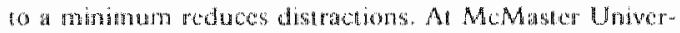
sity, "home bases" are used for thtorial grough sestoms, and can also be used for study, dischssions and for reverwing

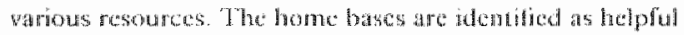
for stuctents thave a place to call their own, and to antedt

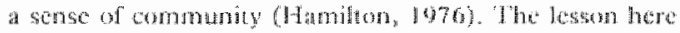
spperars to suggest a strough need tho identify and not

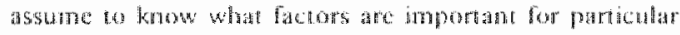
sudents in cresting an aflective elimate for proup functionings.

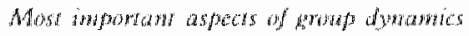

lixaminag motr imponam perspectiwes on group dyom 
ics by themed, ir wat atot surprising that at the beginning of

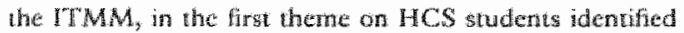
itums related to communication, listering io each other, participation, interest in the growp and having all follow the plan as most imporame (Table 2). At this stage studerts did nor know each other well erough, and they were new io PBL and group work.

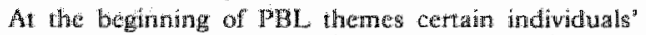
communucation conributions nay be hindered by unfamiliarity not only with tutors, but with group mombers and group lasks (Anderton, 1993). For succeding themes intertion aspers ach as commumcation and listang remained very important isues for the groups, demonstrating that students themselves identified a need, perhapo, for more facilitation with aspects of communication echoing findings by Hartion of al, (1996). These study finding highlight the nesd to thdoes grotup commurication and growp furctioning issues in a non-PBL setimg. If students are to get maximal benefit from PBL, address. ing commurication and social skills issues separately would benefit we PIL groups themselves. Medical students at the Unversty of Limbarg in Mastricht experiance communtcation and social skills training parallel to the PBL program thoughout their medical curriculum (Vin Daten at al, 1989).

Krowing, being cladr, understanding the goats of $\mathrm{P}^{\mathrm{P}} \mathrm{BL}$ and the objectwes of themes were itemis identifed as most important by PBL. groups in subsequent themes (Table 2 ). Low standard deviation $(1.25-1.82)$ demonstrated that there way a high consensus amongust groups as to the irmportanee of producuivity items. Studonts' written commethts elaborated on why certain frens were important; students folt a mead to have aspects related to the PBI framework and the various theme objectives cmplained in language they could digest more casily. In the study by Tipping er al., (1995), students simularly commented more frequently on productivity areas after the study intervention than befonct.

In the socond PSL theme on AM, students identifed the inporknce of suppon for the student leader. Several

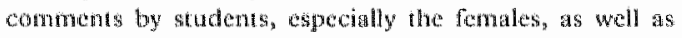
PBl. nitors pointed to the need ro clandy dente the role, of fer more pactice opportunitios for students as leaders. increase the stuchen leader's fesponsibility, and review the nutor"s tole in relationship to that of the student leadier. Skepricsm expressed by some unors dutung thor training

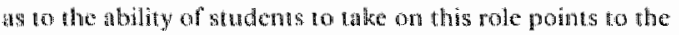
new th inwestigute this area furher. The importance of the affect of turors facilintion on the groups as a wholc diminished in imponance from the turst to the fourth PBL. theme celwoing fordings by Tipping er al, (1995). Howoner, in conturing malis and fernales, the imporance of the tutor"s role remaned farty high as jutged by the dicmenter.

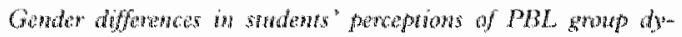
namacs

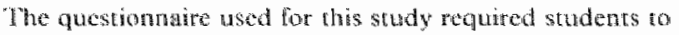
indiche the degree of mpertane of tems in eight categories (Toble 1). On intervicwing group of male and at group of female students to identify their interpretation of bow ther judged an item to be important, the farnals indicated the following:

what is imporiat is what raceds to be present, what is necessary in order to help our learning, understanding and exam success.

On the other harid, a group of malle students interpreted an important irem to be

... an chwirommert that prowides oppormuntes

for each studen to participate.

Firm the outset males and remales appeared to focus on slighty differen aspects of groups: the remales were hom. ing in on "llearning and outcomes" whereas the malles

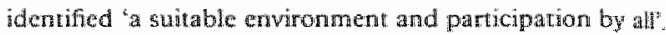
Companing male and female group dynamics perceptions, several areas were identifed as luighy significant ( $)<0.001$; see (Table 1). Female students desired the facilitation of expert tutors, who would flll in any of their knowledge gaps. For the fernale students the group plan having been identified, necded to be executed by all arcording to group rules. It was important to the female studenus to andertake and experience the role of student group laxder. Informal discussions with the tutors indcated that, unlike the malcs, weeks in advance the fomales would highlight to tutors who would act as leader and scribe in subsequent PRI sessions. Galagher (1993) identifed that UAE fernale students, more so than the malc students, were very concerned with proving themselves academically. Not unlike other societies, UAE women have traditionaly playcd more dominant roles in domestic and family afairs rather than as employees out side the housenold. They have a desire, therefore, to develop those cognitive skills and to work hara towards the medical qualification that will enable them 10 function outside the home in a mote competive envinonment. In the PBL group situation gaing factual knowledge was of prime importance to the female as this would lead 10 passing theorefical examsin a step towards that physicifn quatificarion, The malles, on the other hand, desired "ind widual air time". Gender differences demonstrated in out group dynamics study tochod similar findings by Gallaghes (1993)

Our study provides an illumandion of difhering perceplions of pertinem issues regarding group dyandmics in PBL grotaps. It rases inportant furber questions conceming the differing wews on group issues: of male sudents and female students, of sudents as they beome more familar with PBL, and of faculty-student ifferences These issues are important to investigate and feed back into one s local PBB. system. PBL, implementation, the participarts in PBL. programs and also the cowcational enviromment vary from one school to another. The need to develop PBI program? plans that rake account of local issues in areas like group dynamics carnot be over-emphasized. Such research of a highly descriptive nature, in the words of Schon $(1901$, in rich in forcing the world of eduction to stand back and think alwout what it is doing as if is doing it.

\section{Acknowledgements}

The authots are grateful to Jane Tipping, Educationd Consutrant, Unwersity of Toronto Eaculty of Medicine; 
Toronto, Ontario, Canada, for permission to use the quesnonnare. Sincere gratitude goes to all the $\mathbb{E M H S}$, UAE University cutors and students who paricipated in this study

\section{Notes on contributors}

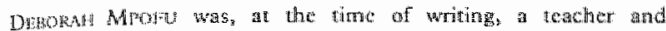
tresarcher an the Faculty of Medicine and Heath Sciences (FMHS) Unied Arab Ernirates (UAE) University. She is now complating PhD studies un Saskanchewan, Canada.

MAvidued Das is an Assistant Protessor in Medical Edweation an the MHHS, UAE Unimersiry. She is the Coardinator of the Chinical Skilss Laboratory, and a module coordurator for the Inroduction ro Medicine Moduls.

Tom Snewant is an Associatc Professor in the Department of Psychiary at the $\mathbb{F}$ MHIS, UAE University.

Wata. V. Dasen is a Professor and the Chatman of the Deparment

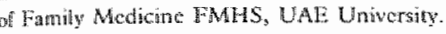

Mt:kK G. Scrmuna is Professor in Paychology at the Universiny of Eimburg, Massinchi, The Netherlands.

\section{References}

BLAANISL, MA. A MTCHELL, S. (1999) Problem-based learning: review of fiteratture on its outcomes andi implementation issues, Acadomic Mrdicine, 68(1), pp. 52-81

ANiterses, C. (1993) Uniwersity students' descripnions of their

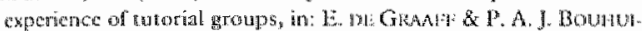

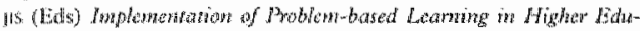
arow, pp. 83-g5 (Amsterdam, Thesis Publishers).

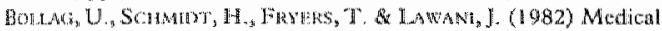
edacation in action: conmumby basch axpericace and service in

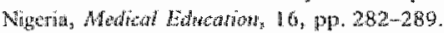

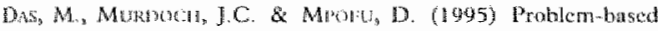
fearning in the Pegenty of Medicine and Health Sciences, United Arab Emärates Uniwersiy, Al-Ain. Foniates Medical Fomal, 13 , pp. 2352246

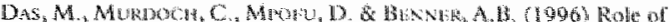

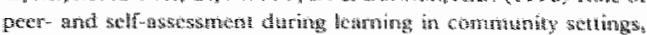

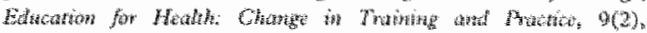
pp. $239-2$.

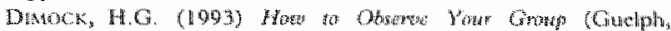
Ontario, Universicy of Gatelph)

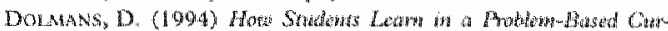

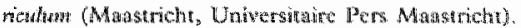

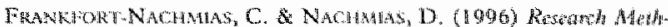

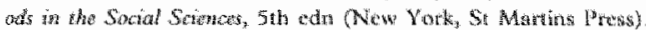

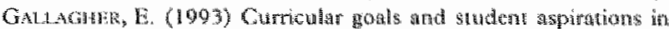

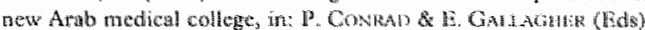

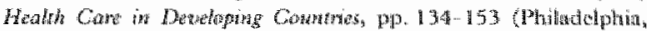
Temple University Press?.

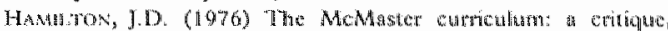

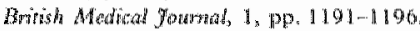

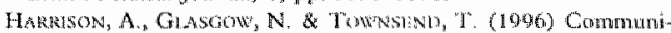
cation skills training farly ir the medicat cumbelum: the UAE

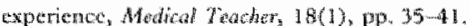

Horsted:,$G$. (1985) Cultural differenes in teaching and leara-

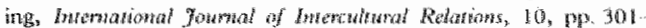
320.

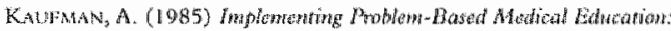

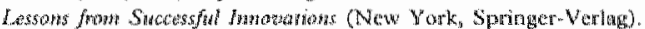

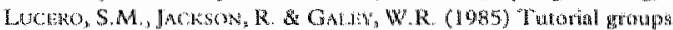

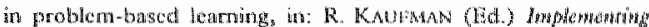

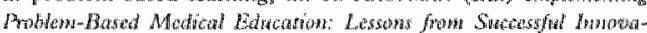
Hons, pp 45-70 (New Yorth, Springer Varlagg h.

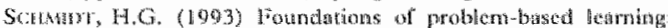

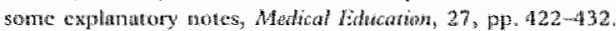

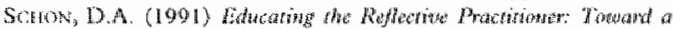

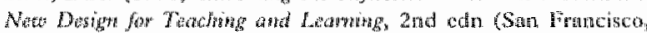
Jossey-Bass?.

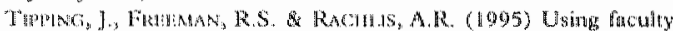
and student perceptions of group dymanies to develog recomp.

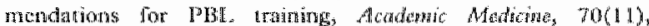
pp. 1050-1052.

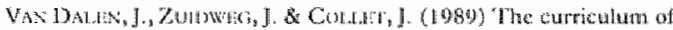
communication skills leaching a Mastrich Medical School, Midical Eduration, 23 , pp $55-61$ 


\title{
Facility with the English Language and problem-based learning group interaction: findings from an Arabic setting
}

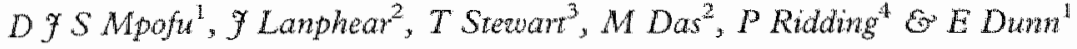 \\ Departunent of Family Medicine, United Arab Emirares Universiry, Al-Ain, Abu-Dhabi, UAE; \\ ${ }^{2}$ Deparment of Medical Edwation, United Arab Emirates University, UAE; \\ ${ }^{3}$ Department of Psychatry, United Arab Emirares University, UAE; and \\ "CMSS Unit, Medical Education, United Arab Enirates University, UAE
}

\section{SUMMARY}

The Faculty of Medicine and Health Sciences (FMHS), United Arab Eminates (UAE) Universigy is a mique position to explore issues related to English language proficiency and medical studert performance. All students entering the FMHS have binghish as a second language. 'This study tochused on the issues of students' proficiency in English as measured by the TOEFL test student background factors and interaction in problembased leaming (PBL) groups. Using a modification of Bales Interaction Process Analysis, four problem-based learning groups were obserwed over four thematic units, to measure the degree of student interaction within PBL. groups and to compare this to individual TOEFL scores and key background variables. The sudents" conuribum tons corrented highly with TOPFL test results in the giving of information (range $\left.j^{n}=0.67-0.74\right)$. The comale students athered 10 interacring in Finglish during group sessions, whereas the male sudents were more likely to ravert to using Arabic in elaborating unclear phenomena $(p<0.01)$. The educational lewel of the student's mother wh highy predictive of TOEFI scores for the male students, but not for female students. Multwariate analysis was undertaken to analyse the relative comiburion of the TOLFL, parental education and years of studyming in taghish. "The best predictlor of students' comtriburions in PBL groups was henched TOEFL scores. "The study demonstrates the importance of facifitating acally acceptabe level of english prom ficioncy prion to admission to the FMHS. However, it aiso highights the importance of not focusing only on English proficiency bul payting atention to additional factors in facilitating medical students in maximzing benefuts from interactions in $\mathbb{P} B L$ setings.

\section{Keywomals}

*Communicarion barriers; Manguages "problem-libad leanning; * studerts, medical

\section{INTRODUCTION}

English is accepted today as a major incrnationd language of medical communication (Maher 1986). Most of the bes contributions in science and medicine are roday published in English in intemational reviews. It is not surprising therefore that the English langugew was adopted as the medium of insitruction at the United Arab Emirates Uniwersicy (UAD), Faculty of Medicine and Health Sciences (FMHS) when it opened in 1986. For all FNHS studenes at UAE University, however, English is a second language. Historically in 1991 , FMHS students" protested at having formal Errglish language unstruction continued during their medical education and training. These studerts would on average have had $7-12$ years of English inscruction in their pre-universiny education, and a yea wh whysh Mathematcs, Computing and Arabic at basic waver sity education lewe The Test of English as a Pregn Language (TOEFL) was therefore introduced in ordeg to give students whose TOEFL: scores were allove 500 (nater changed to 550 ) the opportunicy o opt ot of the English wodules at the FMHS. "The test also provided a bageline, indicating to the FMHS the level of Englistu proficiancy of the seudents who were commencing the study of medicine. It appeared smely to oxthine aspects of oral porticiency in PBL groups and to compure these to students ${ }^{3}$ English hanguage proficioncy as measured by the TOEFL test

\section{A REVIIEW OF THE LITERATURE AND A CASE FOR THE PROPOSED STUDY}

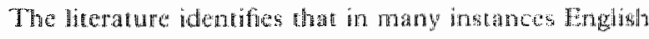
language proficincy cut-off points hate been waty lisined for admission to medical schools, and one of the common tests witlined is the "TOEM test (Graham 1987). Lierature on the tuside of the TOEH test is 


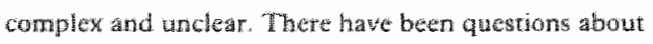
the watue of using multiple chorce professional testis like the TOUI tert for predicting the ablary to use the Engligh language (Dulay at al 1982, Graham 1987). The TOE EW tert measures listeming comprehersion, writen expression, vocabulary and reading. Why therefore should researchers choose ro use this aet to

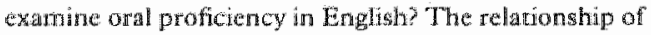
indirect measures hike the TOEFL test to acrive

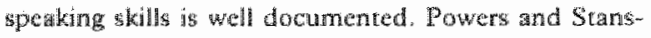
fotd (1983), identify that diroughout the past cernury mutiple-cholce tests have been the primary mode of assesting proficiency in Euglish as at second languget. Multiple choice tests measting sinniar components to the TOEFL test are the Michigan Tost of English Language Proficicncy (MTELP), whe Corrprehensive Engigh Language Test (CET), and the American Language Instute of Coorgetown Unversy (ALCO) test (Powere and Stansfield 1983). None of these vests measure oral proficiency, howewer, research suggests thet the relationshp betwen multiple-choice indrect measures and direct meatures of active speakthg skills is moderately high. Clark and Swinton (1980), Clark (1979), and Pike (1979) hawe demonstrated moderate conrelations beween scores on indirace paper and pencil measures of languge proficiency and performance on tests of active speathing skills. The method of exposure to English is indicated as determining the resultan skils accuired. Other factors that will also affect the profile of language skills are indicated as age, acculturation, purpose for leaming the language and cognitive style Johnson and Newpont 1989).

One of the major gaps identified in the literarure is that most studies that are published were undertaken an western countries whene the study group were foreign students, or refugees, or immigrants, or permanent residens in a cotnty other than their coungry of arigin.

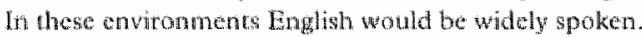
An interesting feature of our context is that out study was undertaken in an fuglish medim madical school. where all students are Arabic and study Dngligh as a starthd language. Their future parients, like the population of the comory, will be very mixed, with Arabic being the mator languge of communicution with parionts, followed by languges such as English and Tindi. Thes situation is unique, as in most studes the idenabed medical students, using English sts a second latuguge aro stadying in wh thatish enviomment, where they ate expected to use English language in communicationg wh partents and in sociallzing. In an Austratian study, owtanlan at af (1995) comenented on $57.1 \%$ af students with ringlish as a second lanmuge, indicating that language skils mindered their parricipation in a pain moduge in PBL. Furher studenes were identified as feding inferior to others, havigg difficultues communcaning in a lecture theratre, diffi-

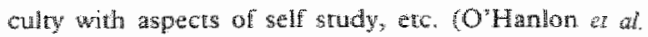
1995). In ow study anecdotal eridence suggested th glish language problems, and this was hightighed in PRL groups and general communicacion sloulls trainimg stuations (Das et al. 1995, Harrison at al. 1995), respectively. Gallagher (1993), in a UAE-based study, highlights how in tis not only language but other cultural and environmental issues that complicat the UAE medical students" aducation and training process. Importan research questons to be addressed in this study are therefore:

1. how do Arabic sudents of differing English profiw ciency levels interact is PBL groups?

2. what tactors infuence English language proficiency (TOEFL, results) and do the same factors influence PBL group contributions:

\section{PROBLEM-BASED LEARNING}

In our setring a group of six to nine students form a tutorial group. Each group is facintated by one or wo wurs, and encounters a wariety of PBL paper problems. For cultural and rulgious rewsons, male students form separate groups to their fernale coumurparts the problem triggers used relate to realwife scenarios and are organized in specific themes. For the Introduction to Medicine Module, the themes addressed are as follows: Heath Care System; Altemative and Islamic Medicine; Family Health; Infectious Diseases and Prevention and Health Promotion. For sach PBL session a different studen directs the group discussion facilitated as necessary by the Faculty turor(s), and the nole of scribe also notates arety session. The description of the problem provoles the group nembers to think, anctivate their pror knowidge; question underlying phenomena; formulare hypotheses; motivace resenth around the dentified tearring objectwes; report back to the group and repest the cycle with exposure to new intormation or further triggers. (Schmide 1993). Using the sudents pror knowledge and researched avidence, the problem analysis that occurs requires processing material in English. Sudtens walk around the educition campus communicating in Arabit and switch to English when the group sessions commence. The English and medical dictionary are a regular accompaninent to the PBL tuwrial room. Sudents also correct each oher"s speling and grammar. In addressing the various PBL steps, members ask questions of other members. This is dentifed as having a postive 
effect on the learning process to both the one asking and the one giving the answer (Peterson and Swing 1985; Webb 1989). This is appecilly the case when open-anded questions are used that require an alaborated response.

\section{METHOD}

In September 1996 during the FMHS orientation week for the 49 newly admited Preparatory Year medical students the following items were administered:

- the TOEFL test;

- a questionnaira used for the survey of new medical entrants.

For dhe Introduction to Medicine Module, sndents were randomly allocated to four female and two male PBL groups, which ramained the same for the whole of the academic year. Using an Interaction Process Analysis (IPA) the study groups were observed during PBL sessions oper four out of five themes. Each theme consisted of three or four PBL sessions, of 2 h duration. Group observation data were correlated with "TOEFL. test results to identify participation patems in relation to English language proficiency. Background survey data were also correlated to rOEFL test results and compared with group observation results.

The data were entered into ACCESS and then imponted into the Statistical Packages for Social Sciences (SPSS) for andysis (Frankfort-Nachmias \& Nachmias 1996). Interaction Process Analysis dact were collected from tutor(s), the student leader, the scribe and group nembers for the categories" 'Asks', 'Grves'; "Elaborates Einglish"; "Seaks clarificarion of English'; 'Arabie' and 'Total', for the roree of four PBL sessions per theme. Four obseners received a training progremme appropriste to the observarional sicuation. Necessary modifications were made to the IPA datacolccting instument in response to comments received from practise applications of the instrument (Frankfort Nachntus \& Nachmas 1906). TOEFL scores were correlated with interaction results. Mean racings and stminad devianons ware calculated over the various obserwation categories. The t-rest was used in analying the follow wh: rale versus femate resule; student Jader versus group members; studen leader versus group tutor(s). Finally information from the background survey data were corelared with TOEFL rest resuls and obserinon results. For the study, the levels of signifounce were identited as follows: significant $<005$, highly significan < 0.01 and wery highly significant \& 0001 .

\section{SUBJECTS}

In Seprember 1996 th sradente 18 males and 31 females), all $\mathrm{UAF}$ cirizens, were admited to the FMHS. During the course of the year ore female and two male students dropped out of the medical ednctton and training progranume.

\section{INSTRUMENTS}

\section{Interaction Process Analysils}

Analysis of communication within health care and medical sertings has been one of the most productive aress of resetnch in the 1980s and 1990s. A by-product of the growth of sudies of patient-doctor communication and other communication studies has been the production, testing and validation of a rumber of bastic methodologies for the analysis of interpersonal intert action in doctor's offices, chincs, hospitals and other serrings. These instruments and tools can be easily adapted to educational group settings. The study group decided to adapt one classical scheme for group analysis, Bales Interaction Procass Analysis (IPA), developed in tine $1950 \mathrm{~s}$.

IPA evolved as a result of an attempt by Bales and others to develop empirical generaliztions about group processes at a dine when the understanding of groups was just emerging (Bales 1950). The focus was upon the basic elements of group interaction and in tine IPA was applied to andyses of classroom internction, psychotherapy sessions, patient-doctor interactions and other social encounters. The code categories and scoring sustems emphasized the basic unis of interac tion (statements versus questions; agrecment versus disagrement, efc) to allow researchers to identify patterns of the most gencral forms. If wath the emphagis upon basic aments that appealled to us in choosing IPA as a method to analyse the PBL process. Another factor that favours the Use of IPA is the long hastory of applation af very clear cote catcerives, which is an

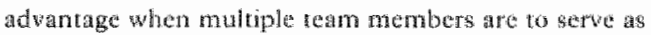
score-obserwers. The code categoribs were axaly leaned and lent themselves to congruence an behovioural obormation.

\section{The TOHEL rest}

"The "Test of English at a Foreign Languge (TOEPL) is a test to measure the lewel of English proficicney of monnatiwe speakers of English. It is generally required by ringlish language colleges and Universitics particuatly in North Anerica. The TOEML test was deweloped for use starting in 1963-64, through the comporative ofort 
of more than 30 orgatizations, beth private and public Wducational Testing Service 1993). A co-operative arrangement for the operation of the TOEFL programme was entered into by the Educational Testing Service, the College Board and the Graduate Record Fuaminations Board in 1973. The Edecation Testing Service is therefore responsible for administering the TOEth programme aceording to the policies determined by a 15 -member Pollicy Council. The TOEFL. test takes approximately 2 h to complete and has three gections: listening comprohension; structure and written expression; and wocabulary and reading comprehension. The three sections convain multiple-choice questions. Listening comprehension test the candidate's abiliny to understand poken English, by liscening to a tape and responding to various types of questions. Structure and written expression assesses a candidate ability to recognize grammatically correct finglish. Vocabulary and reading comprehension demonstrates one"s ability to undersand written English by answering vocabulary and comprehension questions to given passages.

Use of the TOEFL rest with candidates from the Middle East region has been mainly in relation to sndents secking admission to institucions in the USA and Canada (Educational Testing Service 1993).

\section{RESULTS}

\section{Stutlents' TOEFL scores}

The mean TOEFL scores for the two female groups were markedly higher than the mean scores for the male groups. The four student groups had a wide range of TOEFL scores with the males ranging from less than $400 \mathrm{in}$ both groups to just over 600 in one group. The mean total TOEFL score for the femalles was 46820 (SD 42.37) and for the mates 1 was 43.96 (SD 6902), Using the $t$-test this was not significant, $P=0.281$. The mesin TOEHL scores of the study population are very similar to those idtentified in as study undertaken from 1989 ro 1901 of students seakng admisston to the United States of Canada from different pares of the world. The todal TOEFL men score from 1849 UAE candidates was identified as 40 (Educational Testing Service 1993 .

\section{Male versus female participation in PBL groups}

Comparison was made of each student's TOEFL. results and their participation in PBL groups.

With the fernale students, the lower the TOEFL scores, the less likely they were ro ask or giwe information. This was not so for the male studenrs; TOEFL, 2 score and total TOEFL, scores correllated to asking for information $(P<0.035$ and $P=0.000$, respectively). For both male and female students the giving of information was highly correlated to their total TOEFI. score (range of $y=0.67-0.74$ ). Female students were more likely to explain to each orher wsing English. In other words they useci English in discussing unclear words and concepts, until they carne to some understanding. On the other hand the males reverted to Arabic to clarify terms. They were also five times as likely to use Arabic during PBL sessions and this was highly significant, $P<0001$ (Table 1). Possible infleences hare will be addressed larer.

\section{Background student information and factors that were predictive of TOEFL scores}

Survey data were collected during the first week of medical education from the first year students. The students" years of English study ranged from 7 to 13 years, where $75 \%$ had received $9-10$ years of studying in English. Years of studying in English was not correlated to TOEFL scores. Thirry-four students (70.8\%) had mothers whose educational level was primary school or less, and only four students $(84 \%)$ thad mothers who had a uniwersity degree. Twenty-one students $(43 \cdot 8 \%)$ had fathers who had primary school education or less, and 13 stuclents $(271 \%)$ had fathers who had a university degree or nore. "The moher's education level was predicnive of TOEFL scores and highly significant $(P<0.01)$ for the male students. "The mother's education level correlsted highly to mate

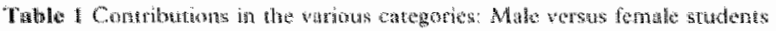

\begin{tabular}{|c|c|c|c|c|c|c|c|}
\hline Sintenten & 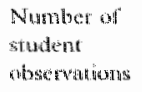 & $\begin{array}{l}\text { Aske miesan } \\
\text { (SD) }\end{array}$ & $\begin{array}{l}\text { Gives mean } \\
\text { (SD) }\end{array}$ & $\begin{array}{l}\text { Elaboration } \\
\text { meara } \\
\text { SDD }\end{array}$ & $\begin{array}{l}\text { Englist: nomenn } \\
(\mathrm{SD})\end{array}$ & $\begin{array}{l}\text { Arrbic mien } \\
\text { SD) }\end{array}$ & $\begin{array}{l}\text { Totel mean } \\
\text { (SD) }\end{array}$ \\
\hline & & & & & & $\ldots \ldots \ldots$ & \\
\hline Ferasice & 283 & $508(8 \% 7)$ & $1704(1459)$ & $0.52(1.45)$ & $0.89(2.17)^{*}$ & $0,56(108)^{* *}$ & $25.34(2356)$ \\
\hline Male & 151 & $44\{\langle 5,2\}$ & 180310100 & $049(1-15)$ & $0.55(1.42)^{*}$ & $260(305)^{4 *}$ & $205 \cdot 4(21 \cdot 1)$ \\
\hline
\end{tabular}

$4 P<005$ and * and 4001 
srudent's TOEHL scoras but not to the female sudenes scores $(r=0.71$ and $r=0.25$, respectively). The fother's education llewel was nor predicule of TOFFL scores, and was not correlated ro TOEFL scores of the male or temale students $(r=0.47$ and $r=0.25$, res pectively). Furthermore, where the mother's education was low sudents were more likely to identify that they bad been discouraged from entering medical school by the fanily, and this was highly significant $(P<0,001)$. Compuring students from Dubai Eminate those from all the aher more conservarive Emirates, the Dubai studants had a nean TOEJ Lcore that was signifi cantly higher than that of students from other UAE Emirates $(P<0.05)$, with a mean difference of 53.3 . A further obserwation was that suctonts with higher TOEFL scores tended to indicate that they were 'worried" or "very worried" about then" ability to grad wate from medical school, as related to their English abiliry, and indicated that they needed more facilitation with Fnglish. The reverse was true of students with tower TOEFL scores.

\section{PBL group contributions versus students" background datat}

lin correlang group contributions whth the students' background data, the mother's educational leval was. mope predictive of students" asking and giving finformation rhan was the tather's level of edtucation. Regression analysis was undertaken to dentify the best predictor of interactions within the studen groups. TOEFL scones were identified as the best predictor of PBL group contubutions. Finally here 31 srudents (646\%) ware interested in going to the United King dom, the United States of America and Canada for postgraduate studies.

\section{DISCUSSION}

Thas 3tudy identifes sereral aspects about fuglish language proficiency and interation in PBL groups. The giving of information as cortated with TOEF1 scones for both male and fermale students. Unlike the femate students, the mate stiders demonstrated less mhibion in asking for hormation, regardiess of ther TOEPL scotes. Ir PBL, nctive stutent participation is

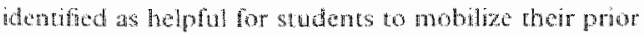
kenutedge. Later, following ruated research. discussions facilitate ataboration and restructuring of krowitedge (Schmit 1903$)$. In our sudy, byever, the famale students with lower TOFFL stores demon. seratred some inhbitons in coming forwart to ask questons ratad to the PBl trigger at hand. Pertaps they did not want to show group menters and at stange tutor their lack of knowyledge. Informal discussions with the student groups identhed two concems. Fustly, some students identified diffouldy wh spoken English. which they perceived as their "private problem" and, with turors they were unfumilat wh, were muln less wocal. Secondly, students indicated not being ranilum with one another at the beginning of the anodule, and this made dhem less free to inderact. Culturally in UA.E, neither the reacher nor the studen should ever be made to lose face (Hofstede $1980,5.312$ ). In spite of Hofstede's comment it is importart to hightight that reluc. tance to expose dificulries that one is experiencing in a turom group is encountered in group situations the world ovea. Charles Anderson, in a study wndertaken in the Faculty of Soctal Sciences in Edinburgh, highights simina problens in their curorial groups. Anderson identified how students openly shdmited lack of willingness 'to lose face wh peers' by admitting they lacked understanding of concepts being discussed in group situtions Further stutents were identified as 'guarded' in idemifying their lack of understanding in aspects of the discussions, because of the false belief that they were the only ones who may be experiencing a difficulty with the topic (Anderson 1993). Although the low proficiency in English attects group contriburions, reluctance to identily oneself as unclear with bsues under discussion also played part in hindering the studentw' contributions in our PBl. groups.

Further in this study the fernale students wert mote likely to adhere to 'rules of the game", speaking and practising using English during PBL sessions. The rnats: students, on the other hand, used more Arabic in clarification of unclear conceps and this was highly significant. The mine sudents apperad to the cxpew rienced socially nore freedom ofl speech and thus cantributed mone casily in PTH. groups. However, thein mean total TOEFl. Score was 43906 wh a withe variation dempmatrated by the sindand dowition of 6902. Hofstede (1986) identies UAl:as a mesteuline stecty, where neth are expected to be assertive, whbitious and competituve. Commontre from observers sug gested that the males not only usited Aratsic more, but

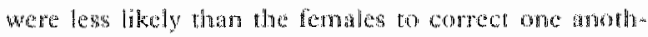
er"s spelling and grammat. "Thas they where more aceepting of the materiol offered, as it was. If pratchisig using Englioh improves hougustic skills, do UAE lomale students improve their Fnglish proficiency moge than when male ceunterparts over a defoned perind of trme? Dara collected by the Finglich language teachers, over the past 2 yeres strongly suggests thas is the cage, however, a sostematic investigethon in this area is strongly recommended. 
Years of studying in Eriglish print to Unversity ducation was not predictive af TOEPL cores, and this was not aredictor of PBU group interaction. The gually of instruction, interaction, and acritices enculuged in reldun to English programmes that studern are exposed to in private and puble schools in UAE wates wemendonsly. Exposure to English is generaly sertricted to the classoum situation, as studenrs revert to Arabic betwern semsions and socially with familics and frierds. Howewer, our resulis suggers that certain factors about liwng in the more commom poltan Dubai fomite generally helps to improve one's English. This sugests that Gertain fentronmentall factors contribute positrely towats one English profin. ciency. Finally here, multivariate analysig identified TOEDI scores (therefore English proficiency) as the

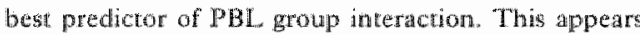
to suggest a wery strong need for maximizing facilitation of the acquisition of Englsh at an carly age for maximal benchi in future edtucational processies such as PBL. This would suppore the studies that identify children was having an adwantage over adults in acquiring a second language (Oycma 1978; Johnson \& Newport 1989).

In our study 34 students $(708$ th) had mothers whose educaional lewel was primary school or less. Sewenteen $(35.4 \%$ actually had mothers who were illiterate and 14 (29.2\%) had fathers who wene illiterate. Howerer, it is important to realize that UAE is near the top of a list of countries with the highest per capita incomes in the word (Gallaglher 1993). Unlike most countries with high jllireracy rates UAE cioes not experience poverty but is adjusting rapidly to progress and devalopment. The students therefore come from financially well - off familics, but for the majority their parents and most of the people in their communities are much less educated than they are. Literature identhes the advantages that a mother's schooling confers on her children's heath, as retates to prenatal care, nutrition, obtaning informa viou on thealth issues, and generally in empowering women on family and other matery (Word Develop ment Report 1993). In our study the mother's education leve correfated highly to male sudents "TOEFL scones (0.71) and not to those of the fenale students. Further, hore, where tho mothers eduran wos low, students were more likety to identify that they had been discouragad from entering madical school athough we canot identify causal relationship. The evidence strongly suggesty that the not aducted the mothen is, the more likely will be the suppore towards schooling ot affprings, which later indirecty reftects on the child's proficincy in English. Further, the more proficient the studem is in English, the beter would be the interaction in PBL groups, specally in giving intormation. Fxactly why the remale sudens appeared less nffected by this situation is not clear.

Finally, 31 students $(64.6 \%)$ indicated a desire to andertake postgraduate studies in the UK, USA, or Carradia. Access to postgraduate studies in these countries gencrally requires a TOEFL score of ar least 550 and is therefore also heawly dependent on a higher level of English language proficiency than our awerage sudent atrans. The messge from our study therefore ask educators to teflect on the rnedium of instruction in medical aducarion and traning. Where English is a second language, strategies like PBL help to identy students with variety of English proficiency problems earty in the medical curriculum. Appropriate metsures need to be locally investigated for providing counsel, not only to the students in training but also to recruitment policies and premiversity educatonal astablishments. Our study reinforces the need to not forget the cruciall role indirecty played by family and the sacial sering in facititating language development, in our case development of Engiesh language within the UAE Ar abic enwironment.

\section{ACKNOWLEDGEMENTS}

The atuors would like to thank all the UAE, FMHS University staffic and students who participated in the study. Further thanks goes to Prot. Henk $G$. Schmidt. Professor in Psychology, University of Limburg. Maastricht, The Netherlands for his comments and suggestions in relation to the manuscript.

\section{REFERENCES}

Anderson $(1903)$ Uniwersty student"s descriptions of theis

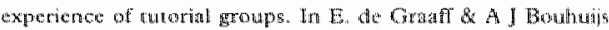

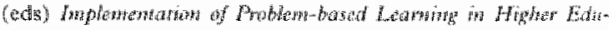

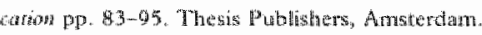

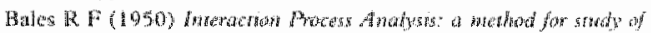

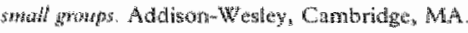

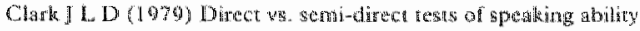

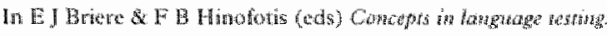

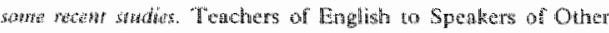
L.anguages, Wastingeon, $D C$

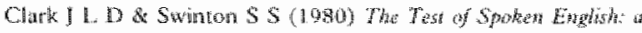

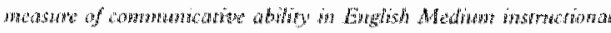

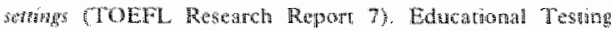
Server, Prinelon, New Jersey,

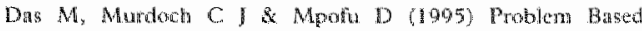

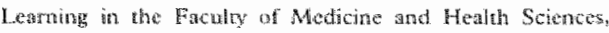

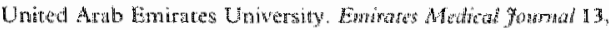
$235 ;-4)$

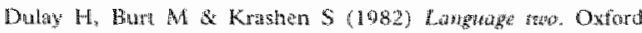
University Press, New Yark. 


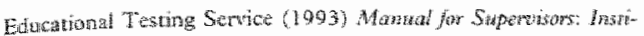

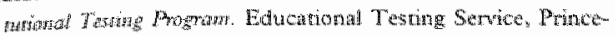
son, Nety Yersey.

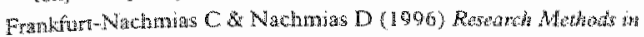
whe Sorat Shathes, 5h edn. St Martin's Press, New York.

Gallagher $\mathrm{z}$ (1993) Curricular goal and sludent aspirations in a new Arab medical college. In P Conrad \& E Gallagher (eds)

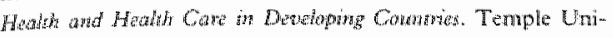
wexiry Press, Philadelphia.

Graham $\& \mathrm{G}(1987)$ Englich language proficiency and the pretichon of acatemic success. TESOL Qendry $21,505-21$.

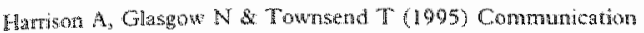
skills tribsing ardy in the medicat curriculum: the UAE

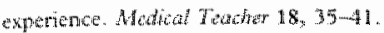

Hofsuede $\mathrm{O}(1986)$ Culural difference in teaching and leaming.

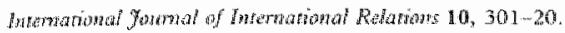

Johnson I $S$. Newpon $E$ L (1989) Cratical period effeces in second language learning: the influenee of maturational sitate on we acquasition of Engtish as a second language. Cogmithe Psychologr 21, 60-99.

Waher I ( 1986 ) The development of English $* 3$ an international

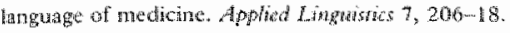

oraton $A$, Whefield $H$, Hejka $\mathrm{E}$ \& Chur-Hansern A (1995) Intial responses of tirs year nuedical students to problenmbased learning in a behavioural science cource. rolle of language

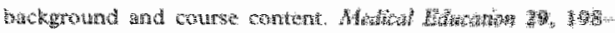
204

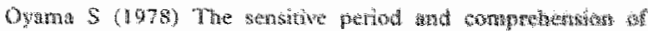

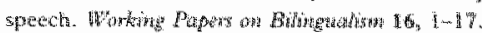

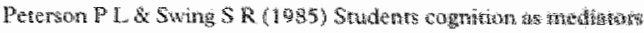

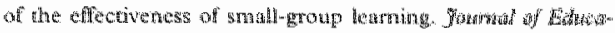
nond Pychology $77,290-312$

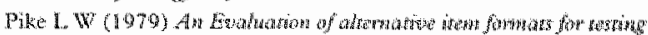

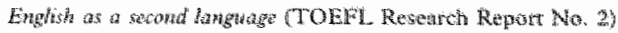

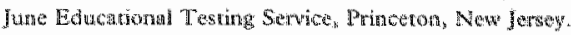

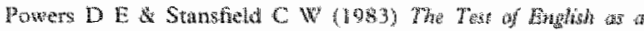

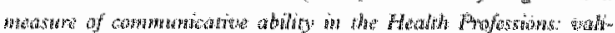

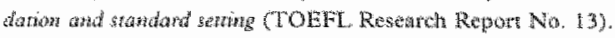
Intwary. Eductional Teang Sewice Princeron, New Jersey,

Sctumid $H \mathrm{O}$ (1993) Foundation of problem-bahed leanum: some explanatory notes. Medial Edwathor 27, 422,32.

Webu N M (1989) Per interaction, and learning in small groups.

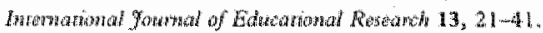

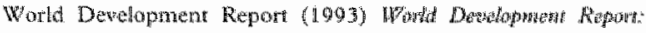

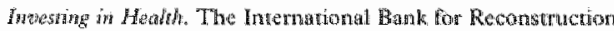
and Development/he World Bank, Oxford Wniwersity Press, New York.

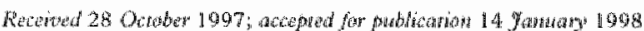




\section{SUMMARY AND CONCLUSION}

At the United Arab Emirates (UAE) University, Faculty of Medicine and Health Sciences (FMHS), a new medical school only a decade old, a major question was why it was necessary to introduce change into the medical curriculum? The defined change would be in the form of Problem-based learning (PBL). Within the study PBL is both a tool for change and a tool to help identufy curricula concerns against maintaining the status quo. PBL is offered not as a substitute for traditional education but complimentary to it.

From the grass roots there were suggestions in the FMHS, that PBL had worked and would work in Canada, the USA, Australia, the Netherlands but not in the Middle East, (Das, Murdoch, \& Mpofu, 1995). Anecdotal evidence suggested that faculty staff felt students at the FMHS were not ready to be given the responsibility for their own learning. The climate was thick with doubt as to the ability of the FMHS students to use PBL. Doubts existed as to whether PBL as a teaching and learning method was worth considering. On the other hand the policy makers had an idealistic perception of what medical education at the FMHS could be like. In theory only, the FMHS identified PBL, the promotion of self and active learning as some of its key curriculum principles. Given this background, it was necessary to cautiously introduce change. Therefore, at the FMHS, UAE University PBL was first introduced into the first year medical curriculum in the Introduction to Medicine Module (ITMM).

The studies conducted focused on the monitoring of, review of, and continued dialogue created by the innovation. The issues addressed in the studies, were as follows:

1. Could PBL be an appropriate learning method for UAE Arabic students?

2. Were students able to use PBL as intended ?

3. What were the merits of introducing a new PBL programme at FMHS?

4. Were PBL concepts comprehensible to tutors, and students?

5. How did the students perceive working as a group in PBL, when they had no experience of group learning?

6. PBL uses post session evaluation by parlicipants, how useful was self-evaluation to students and how was self-evaluation perceived by both students and tutors?

7. Did proficiency with English affect students interaction in groups?

Chapter 2, dealt with iten two and starts to throw some light on item one. Chapter 3 dealt with items three and four. Chapter 4 dealt with item six. Chapter 5 dealt with item three and five. Finally chapter 6 dealt with items seven, and provided more information in relation to items one and three. First year medical students during the Introduction to Medicine Module (TTMM) were randomly assigned to groups and not allowed to change PBL groups for the duration of the ITMM, which was one academic year. Male students and female students were taught separately for cultural and religious reasons. 


\section{Problem effectiveness, and appropriateness of PBL as a learning method}

The focus in chapter 2 therefore, was demonstrating that, given a locally oriented problem, UAE students could comprehensively identify learning issues related to the theme objectives. Demonstrating that our FMHS students could use PBL to direct themselves towards learning issues that would possibly guide their self-study, was a fundamental necessity. This would be assessed by the degree of congruence between staff objectives and student-generated learning activities. Over one academic year in the ITMM, leaming issues were collected from each of six PBL themes. Each theme had four PBL sessions. Learning issues were categorised into the following five headings; biological, behavioural, population, ethical, and critical appraisal. Having five headings to be addressed created room for a large number of learning issues to be identified. Following analysis of learning issues per category students narrowed it down to main objectives/ learning goals in each respective category. However, experts were offered the initial collection of learning issues identified.

Experts to judge the degree of congruence between staff objectives and studentgenerated leaming issues were chosen from well respected senior clinicians and faculty staff. These experts worked independently, and were not involved in any way in the module teaching. In order to reduce subjectivity, in the assessment of congruence of student-generated learning issues to staff objectives by experts, the study had two experts undertake the exercise independently. Kappa coefficients assessed the reliability of the responses by experts, the resultant range of 0.49 to 0.82 indicated a moderate to substantial level of agreement.

There was 100\% concordance of learning issues to theme objectives for four out of six PBL themes. For all the groups the degree of concordance between learning issues and theme objectives varied from 55\% to 100\% (average 91.4\%). For the remaining two themes, which were also the first two themes students were exposed to, the percentage of overlap in the theme Health Care System (HCS) ranged from 55\% to $85 \%$ (average $76.25 \%$ ) and for the theme Environmental and Health (EVH) the percentage of overlap was judged to be $73 \%$ to $94 \%$ (average $87.25 \%$ ). No objective was judged as totally missed out by any student group, although within HCS and EVH certain objectives received superficial attention. The resulis demonstrated that our UAE, FMHS students were able to identify learning issues that related to faculty objectives.

As $100 \%$ concordance of staff objectives to student generated leaming isslues was evident only in the last four PBL themes. It was concluded that the possible superficiality in the addressing of the objectives at the beginning of the PBL. experience was a sign of students' and tutors' in-experience with PBL. Alternatively the problem triggers may have been of poor quality.

Certain concerns were highlighted in relation to the study: 1) Eight of the twelve experts felt there were too many leaming issues being identified especially in the biological and population categories. Fewer learning issues were identified in the other three PBL categories. 2) For the theme on HCS, $12.5 \%$ of the learning issues identificd as having no relationship to theme objectives by experts were further judged as totally irrelewant to the theme objectives. The same was true of $3 \%$ of the learning issues in EVH. The question here was why were students identifying so many learning 
issues? Was this related to the quality of problems presented which were in tum constructed from given faculty objectives? Staff development exercises were initiated by the Medical Education Department, in response to the identified concems relating to the quality of theme objectives and the quality of problem triggers used. The quality and effectiveness of the Introduction to Medicine module objectives was under question. If theme objectives affected problem triggers constructed from them, therefore the quality of problem triggers used in the ITMM would also need attention.

On the other hand, the FMHS students, had a tendency to identify more larning issues related to the biological/physiological, and population aspects of the problem triggers and less learning issues on the behavioural, ethical and critical appraisal issues. This echoed findings by Dolmans (1994), where medical students were identified as more interested in issues related to biological and patho/physiological issues, than social and psychological issues. In other words our UAE, FMHS students were demonstrating similar behaviours to medical students in other countries. On the other hand, some tutors suggested that FMHS students may not have understood the meaning of these PBL categories well enough? This suggestion required further investigation. Chapter 3, reviews understanding of the various PBL dimensions by PBL tutors and students.

The study described in chapter two had demonstrated that FMHS students were perfectly able to identify relevant learning issues in $\mathrm{PBL}$. They were able to use PBL as intended by module planners. As far as identifying learning objectives, PBL was a suitable learning method. However, whether leaming issues once identified would lead to appropriate learning and exam success would need further investigation.

\section{Comprehensibility of PBL dimensions and the merits of PBL}

In chapter 3, the investigators sought to identify the merits of a PBL programme. Further, to review the comprehension of PBL aspects to both students and tutors. Such an investigation was necessary in the light of earlier identified hostility and skepticism regarding PBL at the FMHS. In chapter 2 doubt was expressed as to whether students understood the various PBL dimensions.

A questionnaire published by Majoor, Schmidt, Snellen-Ballendog. Moust, Stalenhoef-Halling, (1990) was adapted for the exercise. The questionnaire used a five point l.ikert scale ranging from full agreement to full disagreenent. The questionnare dealt with; a) how well PBL dimensions were understood by students, from the perspectives of both students and tutors, b) tutors opinions on students and PBL were offered as additional questions, c) other additional questions on students and PBL were offered to the students. Eleven questions on the questionnaire were common to both PBL tutors and PBL students.

Tutor responses, progressed from least consensus in the first PBL theme to the greatest consensus in the final PBL theme. Student responses on the other hand, were more varied from one theme to another. The greatest consensus with the students was in the very first PBL theme, Health Care system (standard deviation 3.40). The least consensus was with the second theme Alternative and Islamic medicine, (standard deviation 6.29 ). In respect of the various PBL dimensions to the astonisiment of the tutors, the students' conservative Moslem background did not inhibit their handling of 
ethical and other perspectives of issues on "drug abuse" or "abortion", pertaining to the theme Altemative and Islamic Medicine. The PBL area students had problems understanding was the concept of "critical appraisal". Some tutors, themselves, lacked current supportive research knowledge on aspects related to the theme under study and also to the concept of critical appraisal itself. The exercise highlighted to the sudents a gap in locally-based research on a variety of topics, simultaneously exposing some tutors" lack of current research knowledge in specific areas. From the students perspective, the major concern identified in the study was that in all the five PBL themes some aspects of the curriculum may not have been covered. Our study had identified concerns reported in other studies, other studies reported that an inability to identify knowledge deficiencies is a phenomenon that PBL students elsewhere have also found uncomfortable (Woodward \& Ferrier 1982). Further, in our study students' commented about their unfamiliarity to working in groups. The study results indicated significant differences in responses to the questionnaire between tutors and students only in the first theme, Heal th Care Systern $(p<0.003)$.

Half of the tutors concern was that students had not searched for relevant reading material, this was suggested for some students as related to low English proficiency. Open ended comments by students themselves echoed concerns about English as a communication barrier in group situations. English language proficiency and participation in PBL groups was therefore subjected to a more in depth investigation, discussed in Chapter 6.

The study demonstrated that the students sufficiently understood PBL dimensions except for critical appraisal. The concern with knowledge deficiencies was not unique to UAE, FMHS students only. The issue of "critical appraisal" was an issue to be addressed for the benefit of both tutors and students. Concern by tutors with aspects of English was an area for future investigation and is addressed in Chapter six. The students identified a lack of current and local research material on a variety of areas. This was and is a very important issue, requiring commitment, support and direction for UAE based medical and health related rescarch, from not only the FMHS, but also the UAE business world, private agencies and the UAE govermment itself.

\section{Self and tutor evaluations in PBL tutorials}

Self, peer and tutor evaluations are an integral part of the PBL tutorial process. Anecdotal evidence at the FMHS identified this as an area of high anxiety amongst the PBL participants, both tutors and students. Reports on experiences related to selfevaluation in PBL are scanty in the literature. Considering the regularity and importance of self evaluation in PBL this was a very important area to investigate. The aim of this study was to identify differences between self and tutor evaluation of students' performances during PBL tutorials. Further, to highlight students' views on self-evaluation and compare evaluation results to achievement at the and of the year.

The study used a form adopted from Rangachari and Crankshaw (1992). Fifteen items on the form represented five subscores, namely: responsibility, information processing, communication, critical analysis, self awareness. Each item was rated from I to 5, from disagrce to agree. Each form further required highlighting of an overall 
score and comments on usefulness or otherwise of self evaluation in PBL. Data was collected over 5 PBL thenes for two academic years.

The results showed that over the two years, comparing self and tutor evaluations, statistically significant differences were present only for the categories of responsibility in 1994 and self-awareness in 1995. The identified reasonable congruence in self evaluation scores between students and tutors, highlighted awareness by students of their strengths and weaknesses. Further, this demonstrated that in most areas students" self evaluation in PBL was as stringent as that by tutors. The students overall ratings of their performance significantly correlated to atl of the subscores ( $p<0.001)$. Tutors overall ratings of students was not correlated. with the students overall ratings except for responsibility.

Eighty per cent of students and $70 \%$ of tutors felt the exercise of scoring self and comparing self-evaluation with tutor evaluation was beneficial, as it not only clarified PBL objectives, but, helped to clarify PBL assessment aspects, and the role of the student. However, the process of form filling was indicated as too time consuming and students were opposed to using self evaluation for summative purposes. In our study, students' self-evaluation scores were fairly high from the beginning, demonstrating a high degree of self confidence. Other studies like Rezler (1989) and Wooliscroft, TenHaken \& Calhoun (1993) found that self-evaluation scores increased as the students progressed over a period of time. Further, in our study, overall evaluation were significantly high for male students than for fernale students (p< $0.0001)$, this was interpreted as due to different gender approaches to evaluative achievement situations. As for written exams at the end of the year using Modified Essay Questions (MEQs), there was no significant correlation between student achievement scores and self or tutor evaluation scores, for all subscores and for overall scores. MEQs were viewed as requiring other skills like a good conmand of English language. The relationship between English language and participation in PBL groups would be investigated in more depth in chapter 6 . In our study, high achievers did not idertify themselves, and self-evaluation of high and low achievers were similar. This was in contrast to findings by Boud and Falchikov (1989), who found that high achieving students tend to underestimate their peformance and low-achieving students overestimate.

The study had clearly showed that the students were not only able to demonstrate responsibility in adopting to self-evaluation as part of PBL, but were able to assess their abilities in concordance with the tutors. The sharing of assessment reports was identified as helpful in developing the students" skills of self-analysis and critical appraisal, important for their future professions as doctors. For the tutors, the exercise fachlitated their opportunity to identify and help students with low confidence and those who were over confident. Although students had previously only experienced traditional educational models which were authoritarian and teacher centred, new approaches to learning like PBL, were facilitating development of a sense of life-long leaming, self-and peer appraisal, which were so important to the long-term profession of doctors. Future investigations were indicated in the ateas of PBL and English, also in the areas of self-evaluation and critical appraisal following graduation from medical school. 


\section{Perceptions of Croup functioning in Problem-Based Learning}

PBL takes place in small groups, of 6-8 students. Studies dedicated to the development of group-related skills are needed as most published studies limit themselves to the development of cognitive skills. In situations like our UAE, FMHS experience, where previous exposure to working in groups is limited, for the first year medical students, investigating group dynamics is important. In study 2 (Chapter 3) the findings suggested a need for reviewing group functioning within PBL small groups.

The aim of this particular study was to investigate views of students and tutors on group dynamics, during PBL group sessions. The issues addressed were as follows: what were the most important and least important dimensions of group dynamics by students and tutors in PBL groups? Further, what were the differing perceptions of group dynamics by students from the first to the last PBL theme, and how did male students and female students differ in their views on group functioning?

Students received PBL orientation, were introduced to the principles of group learning, reviewed the roles of group members, group rules and effective group functioning. They then worked through the various PBL triggers from one theme to another by using the PBL process adopted at UAE University as described in Das, Murdoch \& Mpofu, (1995). On completion of each theme students completed a group dynamics survey form. Tutors completed a similar open ended questionnaire. The survey form used was adapted from Tipping, Freeman, \& Rachlis, (1995). The eight major categories for review were; physical climate, emotional climate, involvement, interaction, cohesion, productivity, the student as group leader, and the tutor as facilitator.

The results demonstrated that aspects related to physical climate, were of least importance to the students, yet more than $70 \%$ of tutors considered physical climate as very important. Too large rooms, unsuitable room lighting, unsuitable air conditioning were very important issues for tutors. Tutors were also less tolerant to seats needing rearranging prior to sessions, students arriving late for PBL sessions and other disturbances caused by students.

Reviewing group dynamics perceptions, the PBL students preferred to ignore deviance withingroups rather than confront a colleague for: not doing their homework, or dominating the group, or repeatedly being late for sessions. Having a powerful individual or subgroups being powerful in a group was highlighted as of no consequence to the group members. By contrast expatriate tutors found students' reluctance to confront deviance within groups, difficult to accept. A faculty-student difference in how to handle these behaviours was indicated. Faculty had their own preconceived ideas as 10 what was important for harmonious group functioning, while the students had totally differing opinions. The findings highlighted a need to clarify from the outset issues related to: being late to sessions and absenteeism. This is important as in the UAE, arriving half an hour late for an arranged appointment is culturally acceptable.

Not only during the first theme HCS, but for succeding themes too, group interaction aspects such as communication and listening remained as very important issues for students. The possible reasons for difficulties in aspects related to 
communication are complex. Communicating easily in as second languge, English, which is only experienced in classroom settings has its difficultics. Where the culture promotes female interaction mainly with females only, and on commencement of medical education and training, being expected to contribute freely in a group where the tutors may not only be expatriates but also male, requires some complex personal adjustment, for the female students. Developing skills in "turn taking" and "listening" to each others contributions was identified as important, but not always practiced by group members. Communication concerns identified in our study, echoed findings by Harrison, Glasgow \& Townsend, (1996), Swadi (1997), suggesting a need perhaps for a communication and social skills training course parallel to PBL and running through out the seven year medical curriculum. In the Skills laboratory at Maastricht Medical school, a communication skills training programme is run from years one to year six, with a gradual increase of complexity in skills the students are exposed to and a gradual increase of complexity in practice situations, Van Dalen, Zuidweg \& Collet, (1989).

Finally, in the present study, concerns relating to the role of student leader versus teacher's role as tutor in PBL groups was identified. This area would require in depth investigation in the future. In over $50 \%$ of questionnaire itens gender differences were evident $(p<0.0001)$. Female students were focusing on learning and outcomes, whereas the male students desired opportunity to individually participate within their groups. These differences were indicated as culturally related echoing previous reports by Gallagher (1993).

The study demonstrates the polarity in faculty versus student interpretation of important issues around group dynamics. It echoes previous findings on the importance of developing the areas of communication skills for the students. It is entirely intended to be descriptive and succeeds in demonstrating how attitudes and previous experiences can influence PBL group functioning. From the students perspective the study suggests that perception of how a group functions can be influenced by cultural experiences and expectations. Innovative educational methodologies like PBL, unilike traditional education, help to highlight the expectations of not only the students but the tutors too. Where PBL tutors and students differ in cultural backgrounds it is not only the students who are "learning to learn" in small PBL groups, but PBL tutors benefit from the experience by learning more about their very own malc and female students.

\section{Facility with the English Language and PBL group interaction}

This study described in chapter 6 aimed at addressing the issuc of English language proficiency and interaction within PBL groups. Funther, it attempted to review factors that influence English language proficiency and identified whether these factors also influence PBL group contributions. In previous chapters 3,4 and 5 a variety of issues were highlighted that pointed to concerns from medical students and or faculty staff at deficiencies in English language being a barrier to sudent participation, interaction, general communication in PBL. It was important to try and investigate the area of English language proficiency more extensively, and try to demonstrate whether PBL was a suitable learning method for UAE Arabic students. 
A tmajor gap identified in literature in relation to proficiency in English of persons whose primary language is different, was that most studies published were undertaken in western countries, where the study group were foreign students or immigrants, resident in a country other than their country of origin. The present study was undertaken in an English medium medical school, where all students are Arabic who studied English as a second language in their own country. The findings would therefore have tremendous importance both locally and internationally.

At the commencement of the Preparatory year, newly recruited medical students were given the Test of English as a Foreign Language (TOEFL), and a questionnaire used for surveying of new medical students. The TOEFL test measures listening comprehension, structure and written expression, vocabulary and grammar. Using an Interaction Process Analysis, the study groups were observed during PBL sessions. The Interaction Process Analysis was based on Bales Interaction Process Analysis (IPA) developed in the 1950s (Bales 1950). The code categories and scoring systems emphasized basic units of interaction. Adapted IPA data was collected from tutor(s), student leader, scribe and group members for the categories: "Asks"; "Gives"; "Elaborates English"; "Seeks clarification of English", "Arabic" and "Total" over four out of five PBL themes.

The mean Total TOEFL scores for the female groups were markedly higher ( $\mathrm{x}=$ 468.20; SD 42.37) than for the male groups $(x=439.96$; SD 69.20). However, the difference was not significant. The results demonstrated that for fermale students the lower their TOEFL scores the less likely they were to ask or give information. In the male groups this was not the case. For both males and females giving of information was highly correlated with their TOEFL score (range of $r=0.67$ to 0.74 ). Thus 'giving information' was mainly explaining phenomena, clarifying issues. Male students were less inhibited at asking questions regardless of their TOEFL scores. Female students with lower TOEFL scores, asked fewer questions. Perhaps they perceived their lower English language ability as their private problem not to be exposed in group sessions. Being restricted by the English language in PBL groups therefore, meant that participation was limited for those respective students.

Fenale students were further identified as speaking and practicing using English during PBL sessions. The males reverted to Arabic to clarify terms. The males students were five times more likely to use Arabic and this was highly significant, $p<0,001$. Male students were also noted as less likely to correct others English spelling and grammar. An interesting future question might be, whether English proficiency as measured by the TOEFL test improves for male students and female students over the undergraduate education and training period?

Years of studying in English were not predictive of TOEFL scores due to the great variation in English instruction from one school to another. Mother's educational level was predictive of TOEFL scores and highly significant for the male students $(p<0.01)$. Father's education level was not predictive nor correlated to male or female students' TOEFL scores. Where mother's education was low, students were more likely to identify that they had been discouraged from entering medical school. Multivariate analysis identified TOEFL scores (therefore English proficiency) as the best predictor of PBL group interaction. 
In our study, English proficiency was therefore demonstrated as affecting students in giwing of information in PBL groups. An important and follow-on question might be, what is the effect of English proficiency on examination success? PBL in this study was therefore highlighted as a leaning method which helped to identily concerns in students ability with the second language, the main medium of instruction. These students would therefore be directed for appropriate counsel early in their medical education and training. From this perspective, PBL had demonstrated its worth and facilitation in highlighting where help was urgently necessary with English Language aspects for respective first year medical students. Yet again this final study highlights how new approaches to learning like PBL, were facilitating clearer identification of gaps within the authoritarian and more teacher centred educational system, simultaneously, highlighting the need for further investigations around PBL.

\section{Conclusion and Recommendations}

The studies identified in chapters 2 to 6 , answer all the questions and issues raised about the innovation. There is identification of how appropriate, worthwhile and ready not only the students but the FMHS is to embrace 'learning to learn' using PBL. In addressing the questions highlighted, a lot of other issues are identified.

From the perspective of the faculty staff, PBL initiated big staff development exercises relating to clearer module objectives and later construction of more effective problems. In working towards an effective PBL programme, the greatest work from faculty appears to be in well thought out and structured ground work. It appears there has to be a vision of the whole picture by cohesive teams bringing in expertise from their respective disciplines, before breaking it down into smaller pieces of the puzzle. Lack of understanding and lack of current knowledge by faculty staff on areas related to "evidence based medicine" were highlighted. Stereotyped beliefs by FMIF PBL tutors of their students were questioned. PBL staff did not think Moslem students conld handle PBL triggers on "abortion" and "drug abuse". Perception of faculty staff versus students views on what was important in group functioning, identified some big differences. These differences it appears were influenced by previous expericnces and expectations. In using self-assessment in PBL, students were demonstrated as stringent as tutors, and positively developing professionally oriented skills towards self-analysis. Proficiency in English was identified as restricting students in giving of information in PBL groups. PBL created and continues to create tremendous educational dialogue locally and intemationally.

In addressing whether PBL was an appropriate leaming method, and whether leaming in groups was positively accepted, centain issues were highlighted. The study demonstrated how PBL facilitated students in verbalizing their difliculties with the subject matter which seemed to remain hidden and domant in the lecture driven curriculum. Communication problems, problems with understanding the language used in explaining the PBL process, English, were identified. Problems with PBL concepts such as critical appraisal were also identificd. In general, a greater awareness of students" difficulties was made possible. Some of these issues point to the problems with basic English language. Would raising the level of TOEFL related to FMHS medical student entry be an answer? More inportantly raising the standards of English 
language instruction and education from primary school level might be of better long term benefits. On the other hand, would introduction of a communication and social interaction module running throughout the medical curriculum be of benefit to those medical students already involved in the FMHS seven year medical education and training curriculum? Repeatedly male versus female differences were identified in a variety of situations, indicated as a reflection of the UAE culture. Paying due respect to the countries culture and religion, what would be the results of mixing the male and female students during the undergraduate education and training period?

This thesis is an attempt to highlight the challenges to students and staff, in the delivery of medical education and training adopting PBL. The major limitation of the study is its broad base. However, in attempting to address issues related to change, this was inevitable. Other limitations are the small number of students who formed the study group, in many respects the study used a convenient sample of participants. On retrospect, data collected over a longer period of time might have been more meaningful. Finally, instruments used for data collection were restrictive in that they were generally modified from other studies. Nevertheless, important findings around student issues, staff issues and communication and English language resulted directly and indirectly from the exercise.

The thesis demonstrates that the process of introducing an innovative approach like PBL in medical education in an institution can never be a carbon copy of another institution's experience. Undertaking research such as this thesis helps create an institutions very own data base.

The thesis in addressing whether PBL was necessary, highlights several fundamental issues that are crucial to the education and training of UAE medical students. The major area highlighted being the use of a second language, English, as the medium of instruction where the students primary language is Arabic. What might be the outcomes of running a comparative programme of PBL in English versus one in Arabic? In other schools where English is a second language for all or nearly all, the medical student cohort, what is the relationship between participation/interaction in PBL groups and English language proficiency? At the FMHS, what is the relationship between participation in PBL groups, English proficiency and achievement? Does proficiency in English improve over the undergraduate years? Further questions here might be, what effect do PBL tutors have on small group interaction? Do PBL tutors have a positive or negative effect on student outcomes? What effect does having two tutors have per PBL group as opposed to having one tutor?

Finally in working towards the millennium it might be an opportune time to evaluate PBL the FMHS and the present status, from the perspective of firstly the graduate students who experienced PBL; secondly, the faculty staff who act and have acted as PBL tutors, finally the supportive network. Some of the studies already published could be expounded on, where data was collected over a longer period of time to boost the sample size.

Results from the various studies making up the thesis have been fed back into the FMHS educational system, and the various publications continue to stimulate dialogue and influence developmental modifications. PBL, since its inception in 1994, has been slowly introduced into other modules other than the Introduction to Medicine 
Module. These modules are: the Behavioural Sciences Module, the Respiratory Module, Clinical Anatomy, Family Medicine clerkship and in 1999 PBL is to be introduced into the Human Sciences Module. Although introduction of the innovation was and still continues to be in segments, as an investigative tool, PBL has unearthed curricula issues that cannot be reburied and forgotten. The thesis has demonstrated the merits of the innovation in exposing concerns that require further research and in the long term further curricula modifications for the benefit of FMHS future physicians. To the FMHS curriculum committee, it would appear that PBL is an educational mode for serious consideration, through out the medical curriculum. This thesis demonstrates the ability of PBL to expose not only students. strengths and weaknesses, but those of the faculty and the educational system. In order for students to gain the best of both worlds, it would appear that the presently more dominant authoritarian and teacher centred curriculum, could be more heavily revised and reduced. With the necessary attention to nesources and manpower, the result would be a curriculum that had a strong PBL base, complimented by an appropriate lecure component.

\section{References}

Bales, R.F. (1950). Interaction Process Analysis: A method for study of small groups. Addison-Wesley, Cambridge, Massachusetts.

Boud, D \& Falchikov, N. (1989). Quantitative studies of students self-assessment in higher education:a critical analysis of funding. Higher Education, 18, 529-549.

Das, M., Murdoch, J.C. \& Mpofu, D. (1995) Problem-based learning in the Faculty of Medicine and Health Sciences, United Arab Eminates University, Al-Ain. Eminates Medical Joumal, 13, 235-246.

Dolmans, D. (1994) How students Leam in Problem-Based Cumicuhm. Universitaire Pers Maastricht, The Netherlands.

Gallagher, E., B. (1993) Curricular Goals and Student Aspirations in New Arab Medical College. In: P.Conrad \& E. Gallagher (Eds.) Healh Care in Developing Countries, (pp. 134-153) Philadelphia, Temple University Press.

Hamison, A. Glasgow, N \& Townsend, A. (1996). Communication skills training early in the medical curriculum: the UAE experience. Medical Teacher, 18, 1, 35-41.

Majoor G.D., Schmidt H.G., Sneller-Ballendog H.A.M., Moust J.H.C. \& StalenhoefHalling B. (1990). Construction of Problems for Problem-Based Loarning. In: Z.M. Nooman, H.G. Schmidt \& E.S. Ezzat (Eds.) Imovation in Medical Education: An Evaluation of its present Stans (pp. 114-122). New York, Springer Publishing.

Rangachari, P.K. \& Crankshaw, D.J. (1992). Formative evaluation a tutorial-based course. In: Proceedings of $5^{\text {sh }}$ Instructional Show and Tell for Ontario Universities. (pp. 125-130). University of Guelph, Guelph, ON.

Rezler, A.G. (1989). Self-assessment in problem-based groups. Medical Teacher 11,2, 151-156.

Swadi. H. (1997) The impact of primary language on the performance of medical undergraduates in communication skills. Medical Teacher, 19, 4, 270-274.

Tipping, J., Freeman, R.S. \& Rachlis, A.R. (1995) Using Faculty and Student Perceptions of Group Dynamics to Develop Recommendations for PBL Training. Academic Medicine, 70, 11, 1050-1052. 
Van Dalen, J., Zuidweg, J.,\& Collet, J. (1989) The curriculum of communication skills teaching at Maastricht Medical School Medical Education, 23, 55-61.

Woodward,C.A.\& Ferrier, B.M.(1982). Perspectives of Graduates Two or Five Years After Graduation from a Three. Year Medical School. Journal of Medical Education 57, 294-302.

Wooliscroft, J.O., TenHaken, J \& Calhoun, J.G. (1993) Medical students' clinical selfassessments: comparisons with external measures of performance and the students" self-assessments of overall performance and effort. Academic Medicine. 68, 285294. 


\section{SAMENVATTING}

De Faculteit Geneeskunde en Gezondheidswetenschappen (FGG) van de Universiteit van de Verenigde Arabische Emiraten (V.A.E.), een nieuwe opleiding geneeskunde die pas tien jaar bestaat, werd geconfronteerd met de belangrijke vraag warom het nodig was om veranderingen door te voeren in het curriculum voor geneeskunde. De omschreven veranderingen betroffen de invoering van Probleemgestuurd Onderwijs (PGO). Binnen het onderzoek is PGO zowel een hulpmiddel bij veranderingen, als een hulpmiddel bij het identificeren van curriculum-problemen bij handhaving van de status quo. PGO wordt niet aangeboden als een vervanging van traditioneel onderwijs, maar als een aanwulling.

Meteen vanaf het begin werd er binnen de FGG geopperd dat PGO wel in Canada, de Verenigde Staten. Australië en Nederland kon functioneren, maar niet in hel MiddenOosten (Das, Murdoch \& Mpofu, 1995). Anekdotisch bewijs wees erop dat de faculteitsmedewerkers vonden dat de studenten van de FGG nog niet zo ver waren dat ze zelf de verantwoordelijkheid voor hun eigen onderwijs konden dragen. El bestond grote twijfel over de vraag of de studienten van de FGG in staat waren om met PGO om te gaan. Men vroeg zich af of het wel zin had om PGO als onderwijs-en leermethode te overwegen. Aan de andere kant hadden de beleidsmakers een idealistisch beeld van hoe het medisch onderwijs aan de FGG zou kunnen zijm. De FGG beschouwde PGO - de bevordering van zelistudie en actief leren - alleen in theorie als een van de grondbeginselen van het curriculum. Gezien deze achtergrond was het nodig om veranderingen omzichtig door te voeren. Daarom werd aan de FGG van de Universiteit van de V.A.E. PGO voor het eersi geintroduceerd in het eerste jaar wan het curriculum geneeskunde in de Module Inleiding in de Geneeskunde (MIG).

Het gedane onderzoek richtte zich op het bestuderen en bespreken van de vernieuwingen, en op de continue dialoog die door de vernieuwingen op gang was gebracht. De vragen die in het onderzoek werden belicht, waren de volgende:

1. Zou PGO een geschikte leermethode kunnen zijn woor Arabische studenten in de V.A.E.?

2. Waren studenten in staat om PGO op de juiste wijze toe te passen?

3. Wat waren de verdiensten van de introductie van een nieuw PGO-programma aan de FGG?

4. Was het concept PGO gemakkelijk te begrijpen voor zowel de tutoren als de studenten?

5. Hoe ervoeren de studenten het werken in een groep in PGO zonder enige ervaring te hebben met hel leren in groepen?

6. PGO maakt gebruik van evaluatie van de bijeenkomst door de dealnemers. Hoe nuttig was zelfevaluatle voor studenten en hoe ervoeren de studenten zowel als de tutoren de zelfevaluatie?

7. Had de mate waarin de studenten het Engels beheersten invloed op de interactie in de groepen?

Hoofdstuk 2 gaat over punt wee en werpt licht op punt éen. Hooldstuk 3 behandelt de punten drie en vier. In hoofdstuk 4 wordt punt zes besproken. Hoofdsluk 5 gaat over punt drie en punt vijf. Het laatste hoofdstuk - hoofdstuk 6 - belicht punt zeven en bevat aanvullende informatie over punt éen en drie.

Eerstejaarsstudenten geneeskunde werden tijdens de Module Inleiding tot de Geneeskunde (MIG) willekeurig in groepen verdeeld. De samenstelling van de groepen moest voor de hele duur wan de MIG (het hele academische jaar) ongewijzigd blijven. Mannelijk en vrouwelijk studenten kregen om culturele en religieuze redenen gescheiden onderwijs.

Effectiviteit van de taken en geschiktheid van PGO als leermethode

In hoofdstuk 2 poogden de onderzoekers aan te tonen dat, gegeven een herkenbaar probleem, studenten in de V.A.E. leerdoelen gerelateerd aan de themadoelstellingen 
ruimschools konden identificeren. Het was een fundamentele noodzaak om te bewijzen dat de studenten van de FGG zich met behulp van PGO konden wijden alan leerdoelen die mogelik richting zouden geven aan hun zelfstudie. Dit zou beoordeeld worden aan de hand van de mate van overeenstemming lussen de doelstellingen van de futoren en de door de studenten ontwikelde leeractviteiten. Gedurende éen studiejaar werden er tijdens de MIG leerdoelen verzameld uil elk van de zes PGO-thema's. Elk thema besloeg vier PGObijeenkomsten. Leerdoelen werden ingedeeld bij een van de volgende vijf categorieën; biologie, gedrag, bevoking, ethiek en kritische evaluatie. Het feit dat er vijf categorieën aangesproken konden worden, gaf rumte aan het identificeren van een groot aantal leerdoelen. Na een analyse van de leerdoelen per categorie beperkten de studenten zich tot de voomaamste doelstellingen/leerdoelen van elk van de viff categorieën. Deskundigen kregen echter de beschikking over de in eerste instantie verzamelde gegevens omtrent de geidentificeerde leerdoelen.

De deskundigen die de male van overeenstemming tussen de doelstellingen van de tutoren en de door de studenten ontwikkelde leerdoelen moesten beoordelen, waren gerespecteerde en ervaren kiniekartsen en faculteitsmedewerkers. Deze deskundigen werkten zelfstandig en waren op geen enkele wijze betrokken bij het onderwijs. Om de subjectiviteit bij het vaststellen van bovengenoemde overeenstemming door de deskundigen te beperken, werd tijdens het onderzoek de toetsing ook door twee onafhankelijke deskundigen uitgevoerd. Met behulp van Kappa-coefficienten werd de mate van overeenstemming tussen de antwoorden van de deskundigen bepaaid. De resulterende verdeling van 0,49 tot 0,82 wijst op een gemiddeld tot substantieel niveau van overeenstemming.

Voor vier van de zes PGO-thema"s was er een overeenstemming van $100 \%$ tussen de leerdoelen en de thernadoelstellingen. Bij alle groepen varieerde de mate van overeenstemming tussen leerdoelen en themadoelstellingen van $55 \%$ tot $100 \% 191,4 \%$ gemiddeld). Voor de overige twee thema"s, welke ook de twee thema's waren waarmee de studenten als eerste kennismaakten, varieerde het overlappingspercentage bij het thema Gezondheidszorgsysteem van $55 \%$ tot $85 \%$ (76,25\% gemiddeld) en bij het thema Omgeving en Gezondheid was het overlappingspercentage volgens de beoordeling $73 \%$ tot $94 \%$ (87.25\% gemiddeld). Er waren geen doelstellingen die volgens de groepen totaal niet aan bod waren gekomen, hoewel aan sommige doelstellingen binnen Gezondheidszorgsysteem en Omgeving en Gezondheid slechts oppervlakkig aandacht was besteed. De resultaten toonden aar dat de studenten van de FGG van de Universiteit wan de V.A.E. in staat waren om leerdoelen te identificeren die betrekking hadden op de doelstellingen van de faculteit.

Alleren bij de latste vier PGO-thema's was er 100\% overeenstemming fussen de doelstellingen van de lutoren en de door de studenten ontwikkelde teerdoelen. Daaruit werd geconcludeerd dat de mogelijke oppervakkigheid bij het behandelen van de doelstellingen aan het begin van de PGO ervaring hel gevolg was van het feit dat de studenten en tutoren geen ervaring hadden met PGO. Aan de andere kant zou het kunnen dat de taken van matige kwaliteit waren.

Een aantal aandachtspunten werd naar aanleiding van hel onderzoek naar woren gebracht.

1) Acht van de waalf deskundigen vonden dat er te veel leerdoelen geidentificeerd werden, wooral in de categorieën biologie en bevolking. In de overige drie PGO-categorieën werden minder leerdoelen geidentificeerd.

2) Bil het thema Gezondheidszorgsysteem werd 12,5\% van de leerdoelen die volgens de deskundigen geen verband hielden met de themadoelstellingen, gezien als totaal irrelevant voor de themadoelstellingen.

Hetzelfde gold voor $3 \%$ van de leerdoelen in Omgeving en Gezondheid. De wraag was waarom de studenten zo veel leerdoelen identificeerden. Hield dit verband met de kwaliteit van de taken "hoewel deze waren samengesteld op basis van de doelstellingen van de faculteit? De afdeling Medisch Ondenwijs startte ontwikkelingstrainingen voor de faculteitsmedewerkers naar aanleiding van de genoemde twijfels omirent de kwaliteit van de themadoelstellingen en de kwaliteit van de taken. Er werden vraagtekens gezet bij de kwaliteit en de effectiviteit van de doelstellingen van de Module Inleiding tot de 
Geneeskunde. Als themadoelstellingen inwloed hadden op de taken die op die doelstellngen waren gebaseerd, dan zou de kwaliteit van de laken die in MG werden gebruikt ook nader bekeken moeten worden.

Aan de andere kant hadden de studenten ven de FGG de neiging om meer leerdoelen te identificeren die verband hielden met de biologische/ysiologische kant en de bevolkingsaspecten van de taken, en minder leerdoelen die verband hielden met ethische en gedragsmatige kwesties en kritische evaluatie. Dit weerspiegelde bevindingen van Dolmans (1994) "waaruit bleek dat geneeskundestudenten meer geinteresseerd waren in biologische en pathofysiologische leerdoelen, dan in sociale en psychologische doelen. Met andere woorden, de studenten van de FGG van de Universiteit van de V.A.E. vertoonden gelijksoortig gedrag als studenten geneeskunde in andere landen. Aan de andere kant waren er tutoren die opmerkten dat studenten van de FGG de betekenis van deze PGOcalegorieän wellicht niet voldoende hadden begrepen. Deze mogelikheid moes: verder onderzocht worden. In hoofdstuk 3 wordt het inzicht van tutoren en studenten in de diverse PGO-dimensies besproken.

Hel onderzoek dat in hoofdstuk 2 wordt beschreven had aangetoond dat studenten van de FGG heel goed in staat waren om de relevante leerdoelen te identificeren. Ze waren in slaat orm PGO op de door de moduleplanningsgroep bedoelde wijze toe te passen. Wat het identificeren van leerdoelen betreft, was PGO een geschikte leermethode. Maar of Jeerdaelen na identificatie to het juiste leer-en examensucces zouden teiden, zou nader onderzocht moeten worden.

\section{Begrijpelijkheild van PGO-dimensies en de verdienste van PGO}

In hoofdstuk 3 probeerden de onderzoekers de verdiensten van een PGOprogramma te identificeren. Verder werd bekeken in hoeverre de diverse aspecten van PGO door zowell studenten als tutoren begrepen werden. Een dergelijk onderzoek was nodig gezien de eerder vastgestelde tegenstand en scepsis omtrent PGO aan de FGG. In hoofdstuk 2 werd twijfel geuit over de vraag in hoeverre studenten de diverse PGOdimensies begrepen.

Een vragenlijst die was opgezet door Majoor, Schmidt, Snellen-Balendong, Moust, Stalenhoef-Halling (1990) werd aangepast woor het onderzoek. De vragenlijst maakte gebruik van een viffpunts-Likert-schaal verlopend van volledig mee eens tat volledig mee oneens. De vragenlijst behandelde het volgende; de mate waarin PGO-dimensies door studenten werden begrepen, vanuit het gezichtspunt van zowel studenten als tutoren, de meningen van de tutoren over studenten en PGO (in aanvullende vragen voor tutoren). vragen ower studenten en PGO (aanvullende vragen voor studenten). Elf vragen van do vragenlijst werdien zowel aan de PGO-tutoren als aan de PGO-studenten gesteld.

De antwoorden van de tutopen liepen op van nauweijks enige consensus in het eerste PGOthema lot de grootst mogelijke consensus in het laatste PGO-thema. De antwoorden van de studenten, daarentegen, varieerden meer per thema. De groofste consensus bij de studenten was in het eerste PGO-thema, Gezondheidszorgsysteem (standaarddeviatie 3,40 ). De minste consensus was er in het weede thema Alternatieve en Islamitische Geneeskunde (standaarddeviatie 6.29). Wat de diverse PGO-dimensies betrof, waren de tutoren werbaasd dat de conservatieve Islamilische achtergrond wan de studenten geen belemmering was voor het behandelen van ethische en andere perspectieven van leerdoelen op hel gebied van drugsmisbruik of abortus, die betrekking hadden op het thema Alternatheve en Islamitische Geneeskunde. Het PGO-gebied dat studenten moeilik vonden om te begrijpen, was het concept kritische evalualie. Sommige tutoren ontbrak het aan recente ondersteunende onderzoekskennis over aspecten van het te bestuderen thema, en ook over het concept kritische evaluatie zelf. Hel onderzoek wees de studenten op een leemte in plaatselijk onderzoek op een groot aantal gebieden, en vestigde legelijkertijd de aandacht op het feit dat het sommige tutoren ontbrak aan recente onderzoekskennis op specifieke gebieden. Het meest verontrustende - vanul het gezichtspunt van de sludenten dat uit het onderzoek, naar voren kwam, was dat binnen elk van de vif PGO-thema's enkele aspecten van het curriculum wellicht niet waren behandeld. Ons onderzoek had bezwaren 
geidentificeerd die in andere onderzoeken waren gerapporteerd. Ander ondezceken gaven aan dat het onvermogen om leemten in kennis aan te wijzen een verschijnsel is dat PGO studenten in andere delen van de wereld eveneens verontrustend wonden (Woodward \& Ferrer, 1982). Verder lieten studenten in ons onderzoek bliken dat ze geen ervaring hadden met het werken in groepen. De onderzoeksresultaten gaven alleen in het eerste thema Gezondheidszorgsysteem - significante verschillen aan tussen de antwoorden van de tutoren en de studenten $(p<0,003)$.

De helft van de tutoren betwiffelden of de studenten wel naar relevante literatuur hadden gezocht. Er werd aangegeven dat dit bij sommige studenten verband hield met hun beperkte beheersing van het Engels. Opmerkingen van de studenten in antwoord op open vragen weerspiegelden hun vrees dat het Engels een belemmering zou zijn bij communicatie in groepssituaties. De beheersing van het Engels in combinatie met actief bijdragen aan PGOgroepen werd daarom aan nader onderzoek onderworpen. Dit wordt besproken in hoofdstuk 6.

Het onderzoek toonde aan dat de studenten de PGO-dimensies voldoende begrepen, met uitzondering van de categorie kritische evaluatie. De bezorgdheid om leemten in de kennis was niet iets wat alleen bij studenten van de FGG van de Universiteit van de V.A.E. voorkwam. De kritische evaluatie was een kwestie die aangepakt moest worden ten behoeve van zowel tutoren als siludenten. De bezorgitheid bij de tutoren over bepaalde aspecten van het gebruik van de Engelse taal was een kwestie die nader onderzoek verdiende en dit komt in hoofdstuk 6 aan bod. De studenten gaven aan dat er een gebrek was aan recent en plaatselijk onderzoeksmateriaal op een groot aantal gebieden. Dit was en is een belangrijk vraagstuk. Het vereist de betrokkenheid bij en steun voor onderzoek in de V.A.E. op het gebied van geneeskunde en gezondheidszorg, niet alleen van de $F G G$, maar ook van het bedriffs!even, van particuliere instellingen en van de overheid van de V.A.E. zelf.

\section{Zelfevaluaties en tutorevaluaties bij onderwijsgroepsbijeenkomsten in PGO}

Zelfevaluaties en tutorevaluaties zijn een integraal deel van de onderwijsgroepsbijeenkomsten binmen het PGO-proces. Anekdotisch bewijs aan de FGG gaf aan dat dit een gebied is dat veel spanningen teweegbrengt bij de deelnemers aan hel PGO, zowel bij tutoren als bij studenten. In de literatuur zijn gegevens over ervaringen met zelfevaluatie in PGO schaars. Aangezien zelfevaluatie in PGO een belangrijke en regelmatig voorkomende gebeurtenis is, was dit een belangrijk gebied om nader te onderzoeken. Het doel van dit onderzoek was het vaststellen van verschillen tussen zelf-en tutorevaluatie van de studieresultaten tijdens onderwijsgroepsbijeenkomsten binnen PGO. Verder werden de meningen van de studenten over zelfevaluatie belicht, en werden de resultaten van de evaluatie vergeleken met de studieresultaten aan hel eind van hel jaar.

Tijdens het onderzoek werd gebruik gemaakt wan een formulier dat van Rangachari en Crankshaw (1992) was overgenomen. Vijtien punten op hel formulier vertegenwoordigden éen van de vijf volgende categorieërn: verantwoordelijkheid, informatieverwerking, communicatie, kritische analyse en zelfbewustzijn. Aan elk punt moest een score varn 1 tot 5 gegeven worden, van mee oneens tot mee eens. Verder werd er gevraagd om op het formulier aan te geven wat de tolaalbeoordeling was en om te reageren op hel nut van zellevaluatie in PGO. De gegevens werden verzameld tijdens vijf PGOthema's gedurende wee studiejaren.

De resultaten toonden aan dat er in de twee jaar bij het vergelijken van de zelf-en tutorevaluaties alleen stalistisch significante verschilen gevonden werden bif de categorie verantwoordelijkheid in 1994, en bil de categorie zelfbewustzijn in 1995. De zelfevaluatiescores van studenten en die van tutoren vertoonden een redelijke mate van congruentie, wat bewees dat de studenten zich bewust waren van hun sterke en zwakke purnten. Verder toonde dit aan dat op de meeste gebieden in PGO de zelfevaluatie van de studenten net zo streng was als die door de tutoren. De totaalscore die de studenten voor hun studieresultaten gaven, had een significant hoge correlatie met alle categorieën $(p<0,001)$. De tolaalscore die de tutoren aan hun studenten gaven, vertoonde geen 
correlatie met de totaalscore van de studenten, met uitzonderng van de categorie verantwoordelijkheid.

Tachtig procent van de studenten en $70 \%$ wan de tutoren vond het utwoeren van een zelfbeoordeling en een vergelijking van de zelfevaluatie met de tutorevaluatie bevordentik. aangezien het niet alleen de PGO-doelstellingen duidelik maakte, maar ook bepaaide aspecten van de $P G O$-evaluatie en de rol van de student hielp verduidelijken. Desondanks werd het invullen van formulieren als te tijorovend ervaren en waren studenten erop tegen dat zelfevaluaties voor summatieve doeieinden werden gebruikt. Tijdens ons onderzoek waren de zelfevaluatiescores van de studenten vanaf het begin tamelijk hoog. wat wees op een hoge mate van zelfvertrouwen. Uit ander onderzoek, zoals dat van Rezler (1989) en Wooliscroft, TenHaken \& Cahoun (1993). bleek dat de zelfevaluatiescores toenamen naarmate de studenten zich over een bepaalde periode ontwikkelden. Verder bleek uil ons onderzoek dat de totaalbeoordeling bij mannelijke studenten significant hoger lag dan bij vrouwelijke studenten $(p<0,0001)$. Dit werd geïnterpreteerd als een gevolg van de verschillen tussen de manier waarop mannen en vrouwen situaties omtrent het evalueren van prestaties benaderen. Met betrekking tot de schriftelijke examens in de vorm van Aangepaste Essayvragen (AEV) aan het eind van het jaar was er geen significante correlatie tussen de prestatiescores van de studenten en zelf- of tutorevaluatiescores voor alle categorieen en voor de totaalbeoordeling. Er werd gevonden dat voor de AEV's andere vaardigheden nodig waren, zoals een goede beheersing van het Engels. De relatie tussen de Engelse taal en het actief bijdragen aan PGO-groepen wordt in hoofdstuk 6 nader onderzocht. In ons onderzoek kwamen high achievers niet naar woren; de zelfevaluaties van high en low achievers waren vergelijkbaar. Dit was in tegenspraak met de bevindingen van Boud en Falchikov (1989), die constateerden dat studenten die goed presteerden de neiging hebben om hun prestatie te onderschatten en dat studenten die slecht presteren hun prestatie overschatten.

Het onderzoek had duidelijk aangetoond dat studenten niet alleen in staat waren om verantwoordelijkheid te tonen door het aanvarden van zelfevaluatie als onderdeel van $P G O$, maar ook dat ze in staat waren om hun vaardigheden vast te stellen in overeenstemming met hun tutoren. Het uitwisselen van evaluatierapporten werd gezien als een hulp bij het ontwikkelen van vaardigheden zoals zelfanalyse en kritische evaluatie bij studenten - belangrijke vaardigheden voor het beroep van arts. Voor tutoren was het een kans om vast te stellen welke studenten weinig en welke te veel zelfvertrouwen hadden em om daarop in te spelen. Hoewel de siudenten voorheen alteen ervaring hadden met traditionele onderwijsmodellen, die autoritair waren en waarbij de docent centraall slond, vergemakkelikten nieuwe onderwijsbenaderingen zoals $P G O$ de ontwikkeling van een gevoel van "leren voor thet leven," zelfevaluatie en evaluatie door medestudenten, wat op de lange termijn zo belangrijk is voor hel beroep van arts. Verder onderzoek op het gebied van PGO en Engels werd gewenst geacht, alsmede op het gebied van zelfewaluatie en kritische evaluatie na het afstuderen.

\section{Inzicht in het functioneren in een groep bij PGO}

PGO vind plaats in kleine groepen van $6 m 8$ studenten. Onderzoek dat gewijd is aan het ontwikkelen van vaardigheden omtrent het functioneren in een groep is noodzakelijk, aangezien de meeste gepubliceerde onderzoeken zich beperken tot de ontwikkeling van cognitieve vaardigheden. In gevalien waarin eerdere ervaring met hel werken in groepen beperkt is - zoals aan onze FGG wart de Universiteit van de V.A.E. - is het belangrijk voor de eerstejaarsstudenten geneeskunde dat groepsdynamiek wordt bestudeerd. In onderzoek 2 (hoofdstuk 3) gaven de bevindingen aan dat er behoefte was aan het bestuderen van het groepsfunctioneren in kleine onderwijsgroepen.

Het doel van dit tweede onderzoek was het onderzoeken van de meningen van studenten en tutoren over de groepsdynamiek tijdens onderwijsgroepsbijeenkomsten. De volgende vraagstukken werden behandeld: wat waren de belangrijkste en wat waren de minst belangrike dimensies van groepsdynamiek volgens studenten en futoren in onderwijsgroepen? En, wat waren de verschillende visies van studenten op groepsdynamiek van het eerste to en met het laatste PGO-thema, en op welke manier verschilden de 
meningen wan de vrouweljke en de mannelike studenten met betrekking tot het functionereiry van de groep?

De studenten kregen PGO-orientatie en maakten kennis met de principes wan het leren in groepen, bestudeerden de rollen van groepsleden, groepsregels en het effectief functioneren in groepen. Vervolgens doorliepen ze de "triggers" van de opeenvolgende thema's met behulp van hel PGOproces zoals beschreven in Das, Murdoch \& Mpofu (1995) en toegepast aan de Unwersiteit van de V.A.E. Na afsluiting van elk thema vulden de studenten een vragenformulier met betrekking tol groepsdynamiek in. De tutoren vulden een soortgelijk formulier met open wragen in. Het vragenformulier was in aangepaste worm owergenomen van Tipping. Freeman \& Rachlis (1995). De acht voornaamste categorieën die aan bod kwamen waren; fysiek klimaat, emotioneel klimaat, betrokkenheid, interactie, cohesie, productiviteit, de student als groepsleider en de tutor als procesbegeleider

De resultaten toonden aan dat aspecten die verband hielden met het fysieke klimaat door de studenten hel minst belangrijk werden gevonden, maar meer dan $70 \%$ van de utoren beschouwde het fysieke klimaat wel als erg belangrijk. Te grote lesruimtes, ondeugdelijke verlichting van die ruimtes en ondeugdelijke airconditioning waren problemen die voor de tutoren zwaar wogen. De tutoren waren ook minder tolerant ten opzichte van het moeten verplaatsen van meubilair woor aanwang van de bijeenkomst, studenten die te laat op de onderwijsgroepsbijeenkomsten verschenen en ander oponthoud dat door studenten werd veroorzaakt.

Bij het bespreken van de visies op de groepsdynamiek gaven de PGO-studenten er de voorkeur aan om afwijkend gedrag binnen de groepen te negeren in plaats wan hun medestudenten aan te spreken op: hef niet doen wan hun huiswerk, het domineren van de groep of het herhaaldelijk te laat zijn voor bijeenkomsten. De aanwezigheid in een groep van een overheersend persoon of een dominante subgroep vonden de groepsleden niet. bezwaarlijk. De buitenlandse tutoren, daarentegen, vonden de onwilligheid van de situdenten om afwijkend gedrag binnen de groep aan de kaak te stellen moeilijk te accepteren. Uit het onderzoek bleek dat faculteitsmedewerkers en studenten op verschillende manieren mel dergelijk gedrag omgingen. De faculteitsmedewerkers hadden hun eigen vooropgezette ideeèn over wal belangrijk was voor het harmonieus functioneren van de groep, maar de studenten hadden daar totaal andere meningen over. De bevindingen wezen op de behoefte om vanaf het begin duidelijkheid te verschaffen over de volgende zaken: te laat komen op bijeenkomsten en afwezigheid. Dit is belangrijk, aangezien het volgens de cultuur van de V.A.E. acceptabel is om een half uur later dan afgesproken op een afspraak te verschinnen.

Niel alleen tijdens het eerste thema, Gezondheidszorgsysteem, maar ook tijdens de daaropvolgende thema's waren aspecten van interactie in groepen, zoals communicatie en luisteren, belangrijke kwesties voor de studenten. De magelijke redenen voor problemen met bepaalde aspecten van communicatie zijn complex. Vrijelijk communiceren in een weede taal - Engels - die de studenten alleen binnen de onderwijsinstelling spreken, brengt problemen met zich mee. In landen waar de cultuur vrouwen aanmoedigt om liever alleen met andere vrouwen om te gaan, wordt er van vrouwelijke studenten aan het begin van hun medische opleiding en training een nogal complexe persoonlijke aanpassing gevraagd. Er van hen wordt verwacht dat ze vrijelijk bijdragen aan een groep mel tutoren die wellicht niet alleen buitenlanders, maar ook nog van het mannelijk geslacht zijn. Het ontwikkeien van vaardigheden op het gebied wan "het om de beurt het woord nemen" en "uisteren naar elkaars bijdragen" werd als belangrijk beschouwd, maar niet altijd toegepast door de groepsleden. Problemen rond communicatie die in ons onderzoek vastgesteld werden, weerspiegelden de bewindingen wan Harrison, Glasgow \& Townsend (1996) en Swadi (1997). wat aangeeft dat er wellicht behoefte is aan een training in communicatieve en sociale vaardigheden die parallel aan het PGO wordt gegeven en die de studenten gedurende het zevenjarige medische curriculum volgen. Het Skillslab van de Faculteit der Geneeskunde van de Universiteit Maastricht biedt een programma voor communicalieve vaardigheidstraining dal van het eerste tot en met het zesde jaar wordt gegeven, met een geleidelijke toename wan complexiteit van de vaardigheden waarmee de studenten 
kennismaken en met een geleidelijke toename wan de complexiteit van praktijksituaties (Van Dalen, Zuidweg \& Collet, 1989).

Ten slotte werden in het huidige onderzaek twijfels omtrent de rol van de gespreksleider versus de rol van de docent als tutor in PGO-groepen geidentifceerd. Dit was een gebied dat in de toekomst nader onderzocht diende te worden. Bij meer dan $50 \%$ van de punten op de vragenlijst bleken er geslachtsgebonden verschillen te zijn $(p<0,0001)$. Vrouwelijke studenten concentreerden zich op leren en resultaten, terwijl de mannelijke studenten graag de kans wilden hebben om zelfstandig deel te nemen binnen de groep. Deze verschillen werden aangeduid als cultuurgebonden, wat ook bleek uit eerdere onderzoek door Gal agher (1993).

Het onderzoek toont de tegengesteldheid aan in de manier waarop de faculteitsmedewerkers en de studenten belangrijke vraagstukken rond groepsdynamiek interpreteren. Het weerspiegelt eerdere bevindingen over het belang van het ontwikkelen van communicatieve vaardigheden voor studenten. Het is volledig beschrijvend bedoeid en het slaagt erin om aan te tonen hoe in PGO houding en eerdere ervaringen het functioneren van een groep kunnen beïnvloeden. Het onderzoek geeft aan dat wat de studenten betreft de perceptie over hoe een groep functioneert beinvloed kan worden door culturele ervaringen en verwachtingen. Vernieuwende onderwijsmethodologieën zoals PGO laten, in tegenstelling tot traditioneel onderwijs, de verwachtingen van zowel studenten als tutoren beter tot uitdrukking komen. In PGO-situaties waarin tutoren en studenten verschillende culturele achtergronden hebben, zijn het niet alleen de studenten die "leren te leren" in kleine PGO-groepen. Ook de tutoren profiteren van de ervaring door meer te leren over hum eigen mannelijke en vrouwelijke studenten.

\section{Vertrouwdheid met de Engelse taal en groepsinteractie bij PGO}

Het onderzoek dat wordt beschreven in hoofdstuk 6 richtte zich op de kwestie omtrent de mate van beheersing van het Engels en de interactie binnen PGO-groepen. Verder is geprobeerd om de factoren die die mate vam beheersing van het Engels beinvloeden, weer te geven en vast te stellen of deze factoren ook invloed hebben op de deetname aan de PGO-groep. In de hoofdstukken 3,4 en 5 werden uiteenlopen wraagstukken belicht waaruit bleek dat geneeskundestudenten en/of faculteitsmedewerkers wreesden dat een gebrekkige beheersing varn het Engels een belemmering zou zijn voor het actief bijdragen van studenten aan groepsdiscussies, interactie en communicatie in PGO in het algemeen. Het was van belang dat gepoogd werd om de aspecten van de beheersing van het Engels nader te onderzoeken en om aan te tonen of $\mathrm{PGO}$ een geschikte leermethode was voor de Arabische studenten van de Universiteit van de W.A.E.

Er bleek een grote lacune te zijn in de literatuur met betrekking tot de beheersing wan het Engels van personen voor wie Engels niet de eerste taal is, omdat de meeste gepubliceerde onderzoeken waren uilgevoerd in westerse landen waarbij de onderzoeksgroep uit buitenlandse sludenten bestond, of uit immigranten die in een land woonden dat niet hun geboorteland wais. Het huidige onderzoek werd uilgevoerd in een instelling voor medisch onderwijs waar Engels de onderwijstaal is, en waar alle studenten Arabisch zijn en in hun eigen land Engels als tweede taal hebben gestudeerd. De bevindingen zouden daarom zowel nationaal als internationaal van groot belang zijn.

Aan het begin van het voorbereidend jaar werd eerstejaarsstudenten geneeskunde een TOEFL-test (Test of English as a Foreign Language) afgenomen. Verder kregen ze een wragenlijst die tot doel had een beeld te krijgen van de nieuwe lichting geneeskundestudenten. De TOEFL-lesl meet lustervaardigheid, zinsbouw, schrifvaardigheid, vocabulaire en grammatica. Met behulp van een interactieprocesanalyse werden de onderzoeksgroepen tijens PGO-bjeenkomsten geobserveerd. De interactieprocesanalyse is gebaseerd op de in de jaren wijftig door Bales ontwikkelde Interactieprocesanalyse (IPA) (Bales, 1950). De codecategorieën en scoresystemen benadrukken elementaire eenheden van interactie. Aangepaste IPA-gegevens werden verkregen van lutor(en) "de gespreksleider, de notulist en groepsleden voor de categorieén "Vraagl", "Geeft", 
"Verduidelikt het Engels", "Zoekt verduidelijking van het Engels", "Arabisch" en "Totaal" lijdens vier van de vijf PGO-thema's.

De gemiddelde totale TOEFL-score lag bij de vrouwelijke groepen aanmerkelik hoger $(x=468,20 ;$ SD 42,37$)$ dan bij de mannelike groepen $(x=439,96 ;$ SD 69,20$)$. Hei werschil was echter niel significant. Uit de resultaten bleek dat naarmate de TOEFL-score bij de vrouwelijke studenten lager was, het minder waarschinlijk was dat ze informatie zouden geven of erom zouden vragen. Dit was niet het geval in de mannelike groepen. Voor zowel mannen als yrouwen bestond er een hoge correlatie tussen het geven van informatie en hum TOEFL-score. (een correlatie varierend van $r=0,67$ tot 0,74 ). Het "geven van informatie" was voornamelijk het verklaren vam verschijnselen, het verduidelijken van bepaalde kwesties. Mannelijke studenten waren minder geremd om wragen te stellen, ongeacht hun TOEFL. scores. Vrouwelike studenten met lagere TOEFL-scores stelden minder vragen. Wellicht zagen zij hun minder goede beheersing van het Englels als een persoonlijk probleem dat ze niet tijdens groepsbijeenkomsten ontmaskerd wilden zien. Het feit dat er in de PGO-groep alleen Engels werd gesproken, betekende voor deze studenten dus dat hun bijdrage beperkt was.

Verder bleek dat vrouwelijke studenten het Engels tijdens PGO-bijeenkomsten bewust spraken en defenden. De mannelijke studenten grepen terug op het Arabisch om termen uit te leggen. De kans dat mannelijke studenten gebruik maakten van het Arabisch was vijf keer groter en dit was zeer significant $(p<0,001)$. Het viel ook op dat de kans dat mannelijke studenten de spelling en grammatica van anderen verbeterden minder groot was. Een interessante vraag die wellicht in de toekomst onderzocht zou kunnen worden is of de beheersing wan het Engels zoals dat was gemeten in de TOEFL-test bij zowel mannelijke als vrouwelijke studenten verbetert tijdens de studie en de training.

Op basis van het aantal jaren dat Engels werd gestudeerd kon geen voorspelling over de TOEFL-score worden gedaan als gevalg van de grote niveauverschillen in onderwijs in Engels van school tot school. Het opleidingsniveau van de moeder was een predictor mel betrekking tot de TOEFL-score en was zeer significant voor de mannelijke studenten $(p<0,01)$. Het opleidingsniveau van de vader was geen predictor en er was ook geen correlatie met de TOEFL-scores van de mannelijke of vrouwelijke studenten. Als het opleidingsniveau van de moeder laag was, dan was de kans groter dat de studenten aangaven dat hen was afgeraden om medicinen te gaan studeren. Uit multivariate analyse bleek dat TOEFL-scores (dus beheersing van het Engels) de beste predictor was voor groepsinteractie.

Uit ons onderzoek bleek dus dat studenten door hun beheersing van het Engels beïnvloed werden bij het geven van informatie in PGO-groepen. Een belangrijke vraag die daaruit voortwloeit is wellicht of de beheersing van het Engels invloed heeft op examenresultaten. Daarom werd PGO in dit onderzoek naar voren gebracht als een leermethode die problemen rond de vaardigheid van de studenten met de tweede taal, hel voornaamste communicatiemiddel in het onderwijs, hielp identificeren. Aan deze studenten zou op die manier in een vroeg stadium tijdens hun studie en training passende hulp gegeven kumner worden. Vanuit dat oogpunt had PGO zijn waarde bewezen; het maakte het gemakkelijker om vast te stellen welke eerstejaarsstudenten dringend hulp nodig hadden bij bepaalde aspecten van het Engels. Weer onderstreepte dit laatste onderzoek dat nieuwe benaderingen van leren zoals PGO het gemakkeliker maakten om leemten binnen het autoritaire, frontale onderwijssysteem te identificeren. Tegelijkertijd wordt benadrukt dat er behoefte is aan verder onderzoek rond PGO

\section{Conclusie en aanbevelingen}

De onderzaeken die in thoofdstuk 2 lol en met 6 worden beschreven, beantwoorden alle vragen en kwesties die de vernieuwing in het onderwijs opriepen. Er is vastgesteld in welke mate de studenten en de FGG er klaar voor zijn om "leren te leren" door middel van $P G O$, en of dit systeem geschikt is en of hel de moeite waard is om het toe te passen. Bij het beantwoorden van bovengenoemde vragen wordt een groot aantal andere kwesties geidentificeerd. 
De toepassing van PGO had gevalgen voor de faculteitsmedewerkers. Het was de aanzel tot speciaal voor de staf ontworpen omvangrijke ontwkkelingsprogramma's die gericht waren op duidelijkere doelstellingen van de modules en vervolgens de construotie van effectievere taken. Bij de totstandkoming valn een effectief PGO-programma lijkt het meeste werk van de faculteitsmedewerkers te liggen in weldoordachte en gestructureerde voorbereidingen. Het bleek dat de hechte teams die elk sipecialistische kennis uit hun eigen disciplines inbrengen eerst een idee van het totaalbeeld moeten hebben, voordat het geheel in kleinere onderdelen gesplitst kan worden. Gebrek aan begrip en aan recente kennis bij de faculteitsmedewerkers op gebieden die verband hielden met "op onderzoek gebaseerde geneeskunde" werden naar voren gebracht. Stereotiepe opvatingen van PGO-tutoren aan de FGG over hun studenten werden aan de kaak gesteld. PGO-medewerkers geloofiden niet dat Islamitische studenten de PGO-taken over abortus en drugsmisbruik zouden kunnen analyseren. Er werden grote verschillen vastgesteld tussen de meningen van faculteitsmedewerkers en studenten over wat belangrijk was voor het functioneren van een groep. Deze verschillen leken beinwloed te worden door eerdere ervaringen en verwachtingen. Bij het toepassen van zelfevaluatie binnen PGO bleken studenten net zo streng te zijn als tutoren en op positieve wijze beroepsgeoriènteerde vaardigheden met betrekking tot zelfanalyse te ontwikkelen. Beheersing wan het Engels bleek studenten te beperken bij het bijdragen van informatie in PGO gang op het gebied van onderwijs, een dialoog die nog steeds gaande is, zowel plaatseiljk als op internationaal niveau.

Terwijl er werd gekeken of PGO een geschikte leermethode was, en of leren in groepen op positieve wijze werd geaccepteerd, kwamen bepaaide vraagstukken naar voren. Het onderzoek toonde aan dat PGO studenten in de gelegenheid stelde om hun problemen mel de leerstof te verbaliserem. Bij het traditionele curriculum leken problemen met de leerstof vaak verborgen of onopgemerkt te biliven. Communicatieproblemen, problemen bij het begrijpen van de taal die werd gebruikt bij het verklaren van het PGO-proces - het Engels - werden geïdentificeerd. Problemen met PGO-begrippen zoals kritische evaluatie werden eveneens in kaart gebracht. Over het algemeen werd er een grotere bewustwording van de problemen van de studenten mogelijk gemaakt. Sommige van die problemen wijzen op problemen met elementaire kennis van het Engels. Zou het verzwaren van de TOEFL. test mel betrekking tot de toelating van studenten aan de FGG een oplossing zijn? Het verbeteren van de kwaliteit van het vak Engels op lagere en middelbare scholen zou op de lange termijn meer succes opleveren. Aan de andere kant is het de vraag of de introductie van een module communicatie en sociale interactie die gedurende het gehele curriculum aangeboden zou worden van nut is voor studenten die reeds bezig zijn mel de zevenjarige medische opleiding en het trainingscurriculum aan de FGG. In verschillende situaties bleken er herhaaldelijk verschillen tussen mannen en vrouwen te zijn, die werden aangemerkt als een afsplegeling wan de cultuur in de V.A.E. Wat zou het resultaat zijn als mannelijke en vrouwelijke studenten - met inachtneming van de cultuur en de religie van het land - lijdens hun opleiding en training gemengd onderwijs kregen?

Dif proefschrift is een poging om de aandacht te westigen op de uildagingen waamee faculteilsmedewerkers en studenten geconfronteerd worden tijdens het proces waarbij hel medisch onderwijs en de training overgaat op PGO. De grootste beperking wan het onderzok is de bredie basis. Aangezien getracht is om kwesties te behandelen die verband houden met veranderingen, was dit echter onvermijdelijk. Een andere beperking is het kleine aantal studenten waaruit de onderzoeksgroep bestond. In vele opzichten maakte hel onderzok gebruik wan een woor de hand liggende steekproef. Achteraf gezien waren gegevens die ower een langere periode waren verzameld wellicht betekenisvoller geweest En tol slot waren de instrumenten die woor het verzamelen van gegeven werden gebruik beperkt in de zin dat ze doorgaans aangepast overgenomen waren wan andere onderzoeken. Niettemin zijn er uit het onderzoek op directe en indirecte wijze belangrijke bevindingen voortgekomen omtrent kwesties die verband houden met studenten. faculteitsmedewerkers, communicatie en de Engelse talal. 
Het proefschrift toont aan dat het introductieproces van een vernieuwende benadering zoals PGO in het medisch onderwijs in een instelling nooit een exacle kopie kan zijn van de ervaringen van een andere instelling. Hel doen van onderzoek zaals dit proefschrift helpt een instelling bij het opzetten van een eigen databank.

Met betrekking tot de waag of PGO noodzakelikk was, bespreekt het proefschrift een aantal fundamentele kwestles die van cruciaal belang zijn voor het onderwijs en de training var studenten geneeskunde in de V.A.E. Het belangrijkste gebied waaraan aandacht wordt geschonken is het gebruik van een tweede taal, het Engels, als het communicatiemiddel in het anderwijs, terwill de eerste taal van de studenten Arabisch is. Wat zouden de resultaten zijn als er een PGO-programma werd opgezet waarbij een Engelse en een Arabische versie vergeleken werden? Wat is de relatie tussen bijdragen/interactie binnen PGO-groepen en beheersing van het Engels bij andere opleidingen waar Engels de tweede taal is voor alle, of bijna alle studenten geneeskunde? Wat is aan de FGG de relatie tussen deelnemen aan PGO-groepen, beheersing van het Engels en prestaties? Verbetert de beheersing wan het Engels tijdens de opleiding? Een andere wraag zou kunnen ziln welk effect PGO-tutoren hebben op interactie in kleine groepen. Hebben PGO-tutoren een positief of negatief effect op de prestaties van de studenten? Wat zou het effect zijn van twee tutoren per PGO-groep in plaats van één?

Tenslotte zou het in verband met het naderende millennium een passend moment zijn om $\mathrm{PGO}$, de $\mathrm{FGG}$ en de huidige situatie te evalueren. Ten eerste een evaluatie van de mening van de studenten die PGO hebben genoten, en ten tweede van de faculteitsmedewerkers die de rol van PGQ-tutor hebben vervuld, en ter slotte van het ondersteunende netwerk. Een aantal van de reeds gepubliceerde onderzoeken waarbij over een langere periode gegevens zijn verzameld, zou voortgezet kunnen worden om de steekproef te vergroten.

De resultaten van de diverse onderzoeken die dit proefschrift omvat, zijn teruggekoppeld naar het onderwijssysteem van de $F G G$, en de diverse publicaties houden de dialoog gaande en blijven invloed uitoefenen op ontwikkelingsaanpassingen. Sinds de invoering in 1994 is PGO behalve bij de Module Inleiding in de Geneeskunde ook geleidelijk toegepast bij andere modules. Deze modules zijn: Gedragswetenschappen, Ademhaling, Klinische Anatomie en Huisartsenassistentschap. In 1999 wordt PGO in de module Menswetenschappen geintroduceerd. Hoewel de introductie in het verleden en ook nu nog in segmenten plaatsvindt, heeft PGO als onderzoeksinstrument wraagstukken mel betrekking tol het curriculum maar boven gebracht die niet opnieuw weggestopt en vergeten kunnen worden. Het proefschrift heeft de waarde van de vernieuwingen aangetoond door kwesties aan het licht te stellen die in de toekomst nader onderzocht moeten worden, en door aan te geven wat eir op de lange termijn aam het curriculum aangepast moet worden ten behoeve van de toekomstige artsen die de FGG opleidt. Het zou de curriculumcommissie van de FGG duidelijk worden dat PGO een ondemwismethode is die in aanmerking komt woor het gehele curriculum. Dit proefischrift bewijst het vermogen van $P G O$ om niet alleen de sterke en de zwakke kanten van studenten te openbaren, maar ook die van de faculteit en het ondewijssysteem. Teneinde studenten het beste van twee werelden te bieden, lijkt hel erop dat het op hel moment overheersende autoritaire en frontale onderwijs grondiger herzien en ingekrompen zou kunnen worden. Met de benodigde aandacht aan geidmiddelen en mankracht zou het resultaat een curriculum kunnen zijn met een sterke PGO-basis, aangevuld met een daarop aansluitende serie hoorcolieges. 


\section{CURRICULUM VITAE}

Deborah Mpofu was born in Zimbabwe, where she undertook all her basic education up to "A" Level. She went to the United Kingdom for higher and University education. Having completed a basic nursing and midwifery programme, she in 1984 completed a B.Sc. degree in Nursing and Health Sciences, at the Metropolitan University of Manchester. She proceeded to complete a Community Health Visitors" programme in 1985 and worked as a health visitor under Stockport Area Health Authority until 1990. In 1992, she completed a Post Graduate Teachers Diploma at Wolverhampton Polytechnic and then worked at the Metropolitan University of Manchester as a lecturer in Health Visiting. In 1993, she completed a Masters in Education with the University of Manchester. From $\mathbb{1 9 9 3}$ to 1997 she worked as a teacher and researcher at the Faculty of Medicine and Health Sciences (FMHS), United Arab Emirates University, in the Arabian Gulf. Her Ph.D. thesis is based on work undertaken at the FMHS. Due to family reasons she moved to Saskatchewan, Canada, where she is pursuing work in Health Sciences research. 